Universidade de São Paulo

Instituto de Biociências

Departamento de Ecologia

Rodolpho Credo Rodrigues

Influência da estrutura da vegetação sobre a diversidade e detectabilidade das espécies de aves do Cerrado

Influence of vegetation structure on the diversity and detectability of Cerrado birds

São Paulo 



\section{Rodolpho Credo Rodrigues}

\section{Influência da estrutura da vegetação sobre a diversidade e detectabilidade das espécies de aves do Cerrado}

\section{Influence of vegetation structure on the diversity and detectability of Cerrado birds}

Tese apresentada ao Departamento de Ecologia do Instituto de Biociências da Universidade de São Paulo como requisito para a obtenção do título de Doutor em Ciências.

Área de Concentração: Ecologia

Orientador: Prof. Dr. Paulo Inácio de Knegt

López de Prado

\section{Versão corrigida}

(O original encontra-se disponível no Insitituto de Biociências da USP)

São Paulo 


\section{Ficha catalográfica}

Rodrigues, Rodolpho Credo

Influência da estrutura da vegetação sobre a diversidade e detectabilidade das espécies de aves do Cerrado

Número de páginas: 118 páginas

Tese (Doutorado) - Instituto de Biociências da Universidade de São Paulo. Departamento de Ecologia.

1. avifauna 2.savana 3. heterogeneidade de habitats 4 . modelos hierárquicos bayesianos. I. Instituto de Biociências da Universidade de São Paulo. Departamento de Ecologia.

\section{Comissão Julgadora:}


aos bichos, às plantas e ao povo do Cerrado, dedico! 


\section{Agradecimentos}

Enfim, após estes quatro anos de doutorado, chegou o momento de agradecer formalmente a todos que participaram direta e indiretamente deste trabalho e da minha formação. Foram muitas pessoas importantes nesta jornada, por isso desde já quero agradecer a todos que estiveram presentes e que contribuíram e dizer que cheguei até aqui com muito esforço más me sinto muito feliz!

Primeiro, gostaria de agradecer ao Paulo Inácio, meu orientador, por ser um grande exemplo de pessoa, de pesquisador e principalmente de professor, pela paciência em transmitir seu conhecimento e tranquilidade nos momentos mais difíceis da pós graduação. Gostaria de agradecer também ao prof. Glauco Machado e ao prof. Paulo Guimarães Jr. (Miúdo) pela amizade e pela oportunidade de participar da LAGE, este ambiente incrível, inspirador e aconchegante. Agradeço pela convivência e companheirismo de todos os grandes amigos que fiz neste nosso meta-laboratório, no LET e também na pós, em especial Camila Mandai, Camila Castanho, Renato Lima, Sara Mortara, Marcelo Awade, Leonardo Wedekin, Carlos Candía-Gallardo, Bruno Ribeiro, Renato Coutinho, Melina Leite, Danilo Mori, Luísa Novaes, Ayana Martins, Eduardo Pinto, Jomar Barbosa, Esther Sebástian, Julia Astegiano, Marília Gayarsa, Paula Lemos, Cristiane Millán, Flávia Marquitti, Mariana Vidal, Leandro Tambosi, Lucas Medeiros, Lucas Nascimento, Maikon Freitas, Marina Xavier e Sérgio Souza. Meus sinceros agradecimentos aos professores Alexandre Oliveira, Renata Pardini, Jean Paul Metzger, Márcio Martins, José Carlos Motta Jr., Eduardo Alves e também à Vera Lima, Luís Souza e todos funcionários da pós graduação. Agradeço igualmente aos funcionários do Parque Nacional Grande Sertão Veredas especialmente Zé Rodrigues, 
Dna. Joana, Laura França e Dr. Luiz Seŕgio Martins, Ernane Faria da ONG Funatura e ao nosso guia sr. Antonio Correia da Silva (Toninho Buraco), pela amizade e companheirismo. Quero agradecer também à Viviana Ruiz-Gutiérrez, que contribuiu com ideías e discussões para o terceiro capítulo desta tese e me recebeu no Cornell Lab of Ornithology, além de Jesse Lepak, Alex Lees, Nárgila Moura, Gerardo Gonzalez, Steven Rios, Sara e Eliot Miller, amigos que fiz durante minha curta porém intensa visita ao CLO.

Agradeço também aos amigos de longa data, Dé, Nerão, Douglão, Gu, Thi e Pedrão, além de Pedro Bernardes, Gregório Menezes, Pedro Dias, Renato Gaiga, Michel Garey, Hugo Pereira, Thammy Dias, Ricardo Marcelino, Lucas Jardim e Mário Sacramento, pela parceria incondicional. Agradeço à toda a minha família, dos Credo e dos Rodrigues, em especial minha vó Maria de Lourdes (in memorian), Tia Má, Tio Zé (in memorian), Tio Tatão e Tia Dedeca e aos primos Marina, Mi, Ju, Lê, Tatau, Pi e Carol. Agradeço também aos "agregados" Castro e Crivellenti, especialmente meus sogros Renato e Adriana pelo carinho, ao meu cunhado Rafa e à Ná pela amizade e à pequena Gabi pela doçura. Agradeço aos meu pais, Antonio e Marilena, pelo exemplo de sabedoria, humildade e dedicação e pelo amor e compreensão de sempre. Aos meus irmãos Lê e Thu e minhas cunhadas Lu e Bia, pela amizade, apoio e incentivo e também à recém chegada Elisa pela injeção de alegria em nossas vidas. Por fim, agradeço à Livia, minha esposa e eterna namorada, pelo convívio e crescimento do dia a dia, por compartilhar comigo tantos sonhos e realizações e por ser esta pessoa e companheira tão maravilhosa!

Esta tese/dissertação foi escrita em $\mathrm{LAT}_{\mathrm{E}} \mathrm{X}$ com a classe IAGTESE, para teses e dissertações do IAG. 
Mas levei a minha sina. Mundo, o em que se estava, não era para gente, era um espaço para os de meia-razão. Para ouvir gavião guinchar ou as tantas seriemas que chungavam...Isso quando o ermo melhorava de ser só ermo. A chapada é para aqueles casais de antas, que toram trilhas largas no cerradão por aonde, e sem saber de ninguém assopram sua bruta força... No mais nem mortalma...Dias inteiros, nada, tudo o nada...Não se tem onde acostumar os olhos, toda firmeza se dissolve. Isto é assim. Desde o raiar da aurora o sertão tonteia."

(João Guimarães Rosa, trecho do livro Grande Sertão Veredas) 


\section{Resumo}

Em diversos estudos ao redor do globo, a estrutura e heterogeneidade da vegetação têm sido considerados fatores determinantes para a diversidade de espécies de aves e também de outros grupos de animais. O Cerrado é a segunda mais extensa e mais ameaçada formação vegetacional de ocorrência no Brasil. Esta vegetação típica do bioma das savanas tropicais também é caracterizada por um mosaico de tipo de vegetações, que juntas formam um evidente gradiente ambiental de estrutura e heterogeneidade de vegetação. Na presente tese analisamos a influência da estrutura e heterogeneidade da vegetação sobre a diversidade em comunidades de aves do Cerrado. Nossa expectativa era corroborar a "Hipótese de Heterogeneidade de Habitats", que propõe que quanto maior a estrutura e complexidade da vegetação, maior será a diversidade de espécies.

No primeiro capítulo, realizamos uma compilação sistemática de estudos publicados sobre a diversidade de aves em áreas ocupadas por algumas fisionomias típicas de Cerrado sensu lato (campos, savanas e cerradões), com o intuito de analisar o conhecimento obtido até então acerca da relação entre diversidade de aves e a estrutura da vegetação no Cerrado. Além disto, analisamos também a influência de diferentes métodos amostrais em revelar esta relação. Foram selecionadas 72 amostras de 22 estudos, sendo que estas amostras variaram quanto ao tipo de fisionomia amostrada e o método amostral empregado, além de também estarem disponíveis em diferentes artigos e serem realizadas em diferentes áreas de estudo. Para análises destes dados, utilizamos a análise de modelos lineares generalizados de efeitos mistos (modelo GLM com distribuição de erros poisson), que permite analisar os efeitos de variáveis fixas e aleatórias sobre a variável explicativa (riqueza de espécies). As 
variáveis de efeito fixo foram o tipo de vegetação amostrada (vegetação campestre, savânica e florestal) e o método amostral empregado (ponto fixo, transecto e redes de neblina). Já as variáveis de efeito aleatório utilizadas foram o artigo onde os dados foram publicados, o autor de cada estudo e a localidade geográfica amostrada. O efeito destas variáveis aleatórias poderiam afetar somente os interceptos das relações entre as variáveis fixas e a variável explicativa ou poderiam alterar a magnitude (i.e. inclinação) da relação entre as variáveis fixas e explicativa. Construímos diversos modelos a partir da combinação de variáveis de efeito fixo e aleatório e a seleção do modelo mais parcimonioso foi feito por meio do critério AICc (critério de informação de Akaike corrigido para pequenas amostras). O modelo que apresentou menor valor de AICc (mais parcimonioso) foi aquele que incluiu os efeitos de ambas variáveis de efeito fixo (fisionomia e método amostral) e também um efeito da interação entre estas duas variáveis. Neste modelo também foram incluídos os efeitos das variáveis aleatórias artigo e localidade geográfica sobre os interceptos das relações entre as variáveis de efeito fixo e a variável explicativa. Estes resultados mostraram que não só a riqueza de espécies de aves em nosso estudo variou em função da fisionomia e do método amostral empregado, mas que também a relação entre riqueza e fisionomia também foi diferente dependendo do método amostral utilizado. Portanto, esta interação não permitiu que fosse estimada a relação entre fisionomia e riqueza sem considerar o efeito dos métodos. Já os efeitos das variáveis aleatórias mostraram que a variação estimada nos interceptos entre artigos foi duas vezes maior do que a variação estimada entre localidades geográficas. O efeito da interação entre as variáveis fisionomia e método amostral apontou para a existência de heterogeneidade de detecção entre locais com diferentes fisionomias, além também de um efeito das fisionomias na efetividade dos diferentes métodos amostrais. A influência dos métodos amostrais no número de espécies observadas em cada fisonomia pode ser esperada devido às diferenças intrínsecas dos métodos, já que ponto fixo e transecto são baseados em contatos visuais e auditivos com as espécies, enquanto que o método de rede de neblina consiste na captura passiva das espécies que voam na altura das redes. Assim, redes de neblina podem ser mais efetivas em habitats menos estruturados (por ex. campos limpos e sujos), onde a rede alcança quase todo os estratos de vegetação. No entanto, 
o método de transecto pode ser mais efetivo que o método de ponto fixo em áreas de florestas, pois nestes hábitats as espécies tendem a ter territórios menores e o deslocamento do observador proporciona ao observador cobrir um maior número de terrítórios. Por outro lado, o ponto fixo pode ser mais vantajoso por não produzir ruído e afugentar as espécies, o que pode ser uma desvantagem do método de transecto. Outros fatores, como a experiência e número de observadores, número de pontos amostrais, número de redes utilizadas e comprimento de transectos, podem explicar a grande variação estimada entre os artigos. Uma das maneiras de se contornar estes efeitos metodológicos é utilizar métodos desenvolvidos especialmente para lidar com diferentes probabilidades de detecção entre espécies, entre sítios e até métodos amostrais. Estes métodos podem render dados mais confiáveis para o estudo da ecologia das espécies e poderiam consequentemente contribuir para a elaboração de planos de manejo e/ou conservação mais efetivos.

No segundo capítulo, a relação entre diversidade de aves e estrutura da vegetação foi analisada a partir de dados coletados em campo e utilizando um protocolo de amostragem específico para se estimar e considerar os efeitos da vegetação sobre a detecção das espécies. As amostragens foram realizadas em um dos maiores e mais preservados remanescentes protegidos de Cerrado (Parque Nacional Grande Sertão Veredas-PARNA GSV) e consistiram do registro das espécies de aves em 32 áreas amostrais. Estas localidades foram dispostas em um gradiente de tipos de vegetação de Cerrado, que variaram desde campos limpos e sujos, campos cerrado a cerrados sensu stricto. O cálculo da riqueza de espécies de aves em cada sítio foi realizado através de modelos de ocupação-detecção, adaptados para estimar a riqueza de espécies em comunidades. A vegetação, por sua vez, foi medida a partir de estimativas de presença da vegetação entre 0 e $4 \mathrm{~m}$ de altura, divididos em 16 intervalos de altura de 22,5 cm cada um. Duas variáveis de estrutura foram obtidas a partir de uma análise de componentes principais, que foi aplicada para resumir a variação da presença de vegetação nestes 16 intervalos de altura. Estas variáveis de estrutura vertical da vegetação foram relacionadas tanto com a ocupação quanto com a detecção das espécies, já que em nossas análises a estrutura vertical da vegetação poderia influenciar não só a ocorrência más também a detecção das espécies. O dia e também a temperatura no momento da 
amostragem também foram incluídas como covariáveis que poderiam afetar a detecção. Após a estimativa da riqueza de espécies pelo modelo de ocupação-detecção para comunidades, esta riqueza estimada foi relacionada à estrutura da vegetação por uma função quadrática e usando um modelo bayesiano de metanálise, que permitiu incluir também a incerteza nas estimativas de riqueza na análise. Com o intuito de melhor compreender os efeitos da detecção imperfeita, também foi ajustado um modelo quadrático GLM (distribuição de erros normal) aos dados de riqueza observada. Os resultados mostraram que a riqueza estimada a partir dos dados das 38 espécies mais detectadas durante as amostragens teve uma fraca relação com as duas covariáveis de estrutura de vegetação, sendo que houve uma maior riqueza de espécies em sítios com vegetação intermediária em altura e uma maior riqueza de espécies de aves em sítios onde houve maior presença de vegetação abaixo de $2 \mathrm{~m}$ de altura. No entanto, as relações entre riqueza estimada e estas covariáveis foram menos intensas mas qualitativamente similares às relações entre a riqueza observada e as covariáveis de vegetação. A menor intensidade nas relações da riqueza estimada foi evidenciada principalmente em ambos os extremos do gradiente de estrutura vertical da vegetação e também nas áreas com menor presença de vegetação abaixo de 2 m. Estes resultados mostraram que o efeito da detecção imperfeita pode alterar o efeito da relação entre riqueza de espécies e estrutura de vegetação. Além disso, ao menos para as 38 espécies mais comumente encontradas na área de estudo, os resultados apontam para a importância de todo o gradiente de estrutura da vegetação para a manutenção da riqueza de espécies de aves no Cerrado. Futuros estudos que visem aprimorar o uso destes modelos de ocupação e detecção para comunidades são fundamentais para permitir o uso dos dados de todas as espécies da comunidade. Além disto, outros estudos que se proponham a analisar a dinâmica e composição das comunidades de aves nestes gradientes de estrutura de vegetação são fundamentais para um maior entendimento sobre a ecologia e conservação das aves no Cerrado.

Palavras-chave: avifauna, savana, fitofisionomia, heterogeneidade de habitats, modelos de efeitos mistos, gradiente ambiental, ocupação, detecção, modelos bayesianos hierárquicos, hotspot, conservação. 


\section{Abstract}

In several studies around the world, vegetation structure and heterogeneity have been considered determinant factors for avian diversity and also for the diversity of other groups of animals. The Cerrado is the second most extensive and most threatened vegetal formation that occurs in Brazil. This vegetation is a typical tropical savanna and is characterized by an mosaic of several vegetation types, which forms an obvious environmental gradient of vegetation structure and heterogeneity. In this thesis, we analysed the influence of the structure and heterogeneity of the vegetation on the diversity of Cerrado bird communities. Our expectation was to support the "Habitat Heterogeneity Hypothesis", which suggests that the higher the structure and complexity of vegetation, the greater the diversity of species.

In the first chapter, we conducted a systematic compilation of published studies about bird diversity performed in areas with different Cerrado lato sensu physiognomies, in order to analyse the actual knowledge about the relationship between diversity of birds and the structure of the vegetation in the Cerrado. We selected 72 samples from 22 studies and these samples varied in vegetation physiognomy, sampling method used, and they also were published in different scientific papers and be carried out in different geographical locations. We performed generalized linear effects models analysis (poisson error distribution GLM model), which allows us to analyse the effects of fixed and random variables on the explanatory variable (species richness). Fixed variables were the type of sampled vegetation (grassland, savanna and forest) and the sampling method employed (point counts, transect and mist nets). The random variables were the article where the data 
were published, the author of each study and geographic location. These random variables could affect only the intercepts of the relationships of fixed and random variables with explanatory variable or could alter the intensity (i.e. slopes) of the relationship between fixed and explanatory variable. We built several models from the combination of fixed and random effects variables and selection the most parsimonious model was made by using the AICc criterion (Akaike Information Criterion corrected for small samples). The model that showed lower value of AICc (more parsimonious) was the one that included the effects of both fixed effect variables (physiognomy and sampling method) and also an interaction effect between these two variables. In this model were also included the effects of random variables article and geographic location on the intercepts of the relationship between the fixed effect variables and the explanatory variable. These results showed that besides bird species richness in our study varied due to physiognomy and sampling method variables, the relationship between richness and physiognomy also was different depending on the sampling method used. Therefore, this interaction does not allowed us to estimate the relationship between physiognomy and species richness without considering sampling methods effects. Additionally, the effects of random variables showed that the variation in the intercept among papers was two times larger than the estimated intercept variation among geographic locations. The effect of interaction between the vegetation physiognomy and sampling method variables pointed to the existence of detection heterogeneities between locations, physiognomies, and also between different sampling methods. The influence of the sampling method in the number of species observed in each physiognomy may be expected due to intrinsic differences in the methods, since point counts and transect are based on visual and aural contacts with the species, while the mist net method consists in passive capture of species trying to fly through the nets. Thus, mist nets may be more effective in less structured environments (e.g. grasslands) where the net reaches virtually all vegetation layers. However, transect method can be more effective than the point counts method in forested areas, since in these habitats species tend to have smaller territory areas, and the observer movement provides the observer cover greater areas. On the other hand, point counts methods minimize noise and bird species drive off, which may 
be a disadvantage of transect method. Other factors, such as experience and number of observers, the number of sampling points, the number of nets used and length of transects, may explain the wide estimated variation among papers. One of the ways to overcome these methodological effects is to use methods developed specially to deal with different detection probabilities among species, sites and even sampling methods, which could yield more reliable data for the ecological studies and the development of species management and / or conservation plans.

In the second chapter, the relationship between bird diversity and vegetation structure was analysed from data collected in the field and using a specific sampling protocol to estimate and consider the effects of vegetation on species detections. The samples were taken in one of the largest and well preserved remnants of Cerrado (Grande Sertão Veredas National Park-PARNA GSV) and consisted of recording bird species in 32 areas arranged in a Cerrado structural vegetation gradient, ranging from grasslands, open and dense savannas. Estimated bird species richness at each site was calculated using occupancy-detection models adapted to estimate the number of species in communities. The vegetation, in turn, was measured from estimates of the presence of vegetation between 0 and $4 \mathrm{~m}$, divided in 16 height intervals of $22.5 \mathrm{~cm}$ each. Two structure variables were obtained from a principal component analysis applied to summarize the variation of the vegetation presence in these 16 height intervals. These vegetation variables were related to the occupancy and detection of species, since the vegetation structure could influence not only the occurrence but also the detection of species in our analysis. The sampling day and also the temperature at the time of sampling were also included as covariates that could affect detections. After the estimation of species richness by occupancy-detection models for communities, this estimated richness was related by a quadratic function with the vegetation structure covariates using a Bayesian meta-analysis model, which also allowed us to include uncertainty in richness estimates. In order to better understand the effects of imperfect detection, we also fit a quadratic model GLM (normal distribution errors) to the observed (naive) richness data. The results showed that estimated richness from the data of the 38 most detected species during sampling had a weak relationship with both covariates of vegetation structure, and 
there was a greater species richness at sites with intermediate vegetation height and greater bird species richness in places where there was a greater presence of vegetation below 2 $m$ height. However, the relationsphips between estimated richness and these covariates was less intense but qualitatively similar to the relationship between observed richness and vegetation covariates. The lowest intensity in the estimated richness relationships were observed mainly at both ends of the vertical gradient of vegetation and also in areas with less presence of vegetation below $2 \mathrm{~m}$. These results showed that the effect of imperfect detection can change the effect of the relationship between species richness and vegetation structure. Moreover, at least for the 38 species most commonly found in the study area, these results points to the importance of the entire vegetation structure gradient to maintain the bird species richness in Cerrado. Future studies aiming to improve the use of these models of occupancy and detection for communities are essential to allow the use of data of all species in the community. In addition, other studies that propose to analyse the dynamics and composition of bird communities in these vegetation structure gradients are fundamental for a better understanding on the ecology and conservation of Cerrado birds.

Keywords: avifauna, savanna, vegetation physiognomy, habitat heterogeneity, mixed-effects models, environmental gradient, occupancy, detection, Bayesian hierarchical models, biodiversity hotspot, biodiversity conservation. 


\section{Sumário}

1. Introdução geral . . . . . . . . . . . . . . . . . . . . . 19

1.1 Estrutura da vegetação x diversidade em comunidades de aves . . . . . . . 19]

1.2 Efeitos da Detectabilidade em estudos ecológicos . . . . . . . . . . . . 20

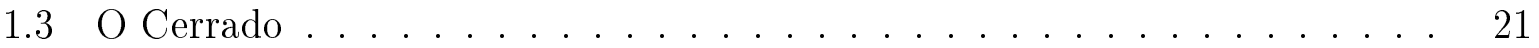

1.4 Objetivo desta tese . . . . . . . . . . . . . . . 21

2. Bird diversity and vegetation structure relationship in Cerrado hotspot, Brazil: Can different sampling methods affect our view of ecological patterns? . . . . . . . . 23

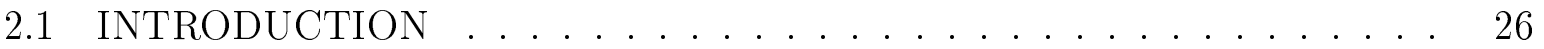

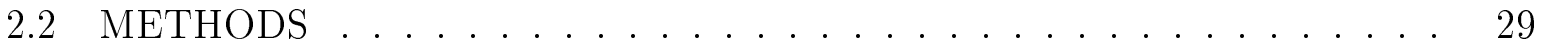

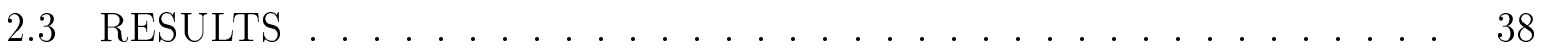

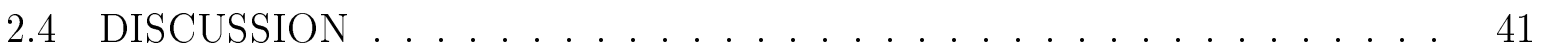

3. Bird diversity and vegetation structure relationship: Effects of vegetation gradients on species richness and detectability in Cerrado savanna, Brazil . . . . . . . . 47

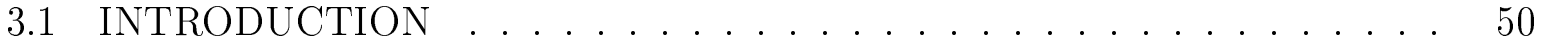

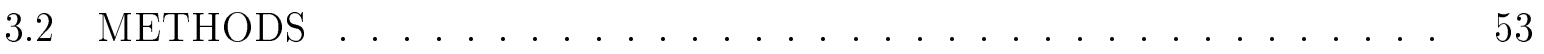

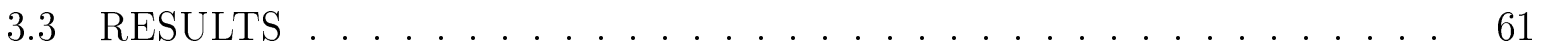

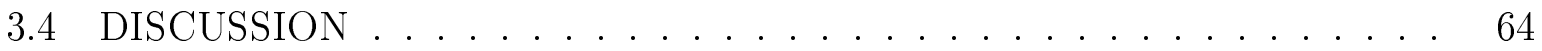

4. Conclusões ................................. 73 


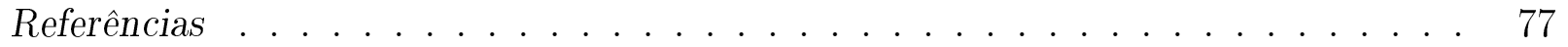

Appendix

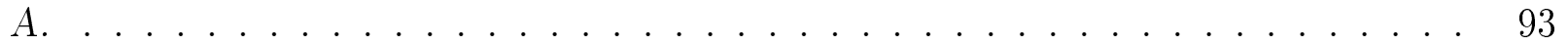

A.1 Databases and keywords used in secondary data search . . . . . . . 93

A.2 Detailed description of surveys locations . . . . . . . . . . . 96

A.3 Detailed description of statistical analyses . . . . . . . . . . 101

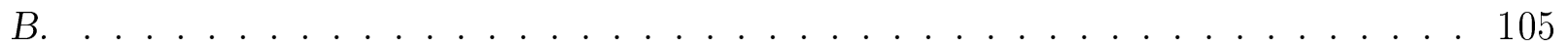

B.1 Bayesian model codes in BUGS language . . . . . . . . . . . . . 105

B.2 Posterior predictive checks of metanalysis models fit . . . . . . . . . 108

B.3 Table of species sampled during surveys . . . . . . . . . . . . . . 109

B.4 Results of species richness and occupancy using all species data . . . . 115 
Capítulo 1

\section{Introdução geral}

\subsection{Estrutura da vegetação $\mathrm{x}$ diversidade em comunidades de aves}

A estrutura da vegetação é uma das variaveis que mais afetam a diversidade em comunidades de aves (MacArthur and MacArthur, 1961; Cody, 1985, Tews et al., 2004). Diversos trabalhos em todos os continentes tem mostrado que variáveis como: tipo de fisionomia vegetal, altura do dossel, perfil vertical da folhagem, densidade e diâmetro das árvores têm grande influência sobre a quantidade de espécies e de individuos presentes nas comunidades de aves (MacArthur and MacArthur, 1961; Rotenberry, 1985; Díaz, 2006; Price et al., 2013, Carrillo-Rubio et al., 2014). A explicação mais aceita para este padrão é a proposta pela "Hipótese de Especialização por Recursos" ("Resource Specialization Hypothesis" (Srivastava and Lawton, 1998)), a qual propõe que uma maior diversidade e distribuição espacial dos recursos no ambiente pode sustentar uma maior diversidade de espécies, por uma maior especialização nos recursos e uma redução na competição entre as espécies. Este pode ser o principal padrão de diversidade em comunidades de aves, visto que alguns trabalhos recentes têm mostrado que o clima, considerado outro fator determinante, afeta as aves principalmente através da sua influência sobre o crescimento da vegetação e não por um efeito direto sobre a ocorrência das espécies Hurlbert, 2004: Kissling et al. 2008, Ferger et al. 2014). As savanas são formações vegetais que apresentam uma grande heterogeneidade espacial e estrutural de vegetação (Doughty et al., 2016). Estas formações são caracterizadas por um mosaico complexo de campos de gramíneas, vegetações arbustivas até florestas, incluindo ainda florestas de galeria e áreas inundáveis 
(Ratter et al. 1997; Price et al., 2013). Fatores abióticos, como fertilidade e profundidade do solo, além da disponibilidade de água e ocorrência de fogo, e também bióticos, como o pastejo por herbívoros, têm relação com a manutenção desta heterogeneidade espacial da vegetação (Ratter et al., 1997; Doughty et al., 2016). Devido ao aumento da fragmentação da vegetação por fatores antrópicos, o estudo destas vegetações espacialmente heterogêneas pode significar uma grande oportunidade para estudos ecológicos e estudo aplicados à conservação de espécies, por proporcionar uma melhor compreensão dos padrões e processos ecológicos em ambientes que são naturalmente fragmentados.

\subsection{Efeitos da Detectabilidade em estudos ecológicos}

Apesar do longo histórico dos estudos ecológicos em geral, o desenvolvimento recente desta disciplina deve-se principalmente à elaboração e aplicação de ferramentas metodológicas e estatísticas cada vez mais modernas e poderosas. Um dos exemplos deste tipo de inovação teórica e tecnológica na ecologia é o desenvolvimento e incorporação da questão da detecção imperfeita em amostragens de populações e comunidade de organismos. A influência do processo amostral sobre as estimativas de diversidade de comunidades já é conhecido de longa data na literatura ecológica (e.g. (Fisher et al., 1943, Preston, 1948)). A partir do final da década de 1970, alguns trabalhos propuseram incluir formalmente possíveis efeitos da heterogeneidade nas probabilidades de detecção das espécies sobre as estimativas do tamanho destas populações (Otis et al. 1978; Burnham and Overton, 1979). Estes métodos foram generalizados no início do śeculo XXI, a partir da implementação destas idéias usando uma abordagem de modelagem hierárquica para ocupação e detecção das espécies (Mackenzie et al., 2002). Inicialmente, estes modelos possibilitaram não só a estimativa de parâmetros associados à presença ou ausência de espécies em comunidades, mas também a consideração do efeito de outras variáveis sobre o processo de observação destas espécies e/ou indivíduos durante as amostragens. Nos dias de hoje, parâmetros como extinção e colonização locais, além de número e composição de espécies em comunidades, por exemplo, podem ser inferidos a partir de métodos computacionais eficientes que permitem a 
estimativas de muitos parâmetros simultaneamente. Estes estudos têm comprovado que a detecção imperfeita pode influenciar de forma substancial a nossa visão dos padrões e processos ecológicos (Gu and Swihart, 2004, Zipkin et al., 2010; Ruiz-Gutiérrez and Zipkin, 2011). Consequentemente, estes erros podem também nos levar à tomada de decisões equivocadas quanto ao manejo e/ou conservação de espécies e áreas naturais e, portanto, devem ser levadas em conta para maiores êxitos no processos de decisão envolvendo estudos ecológicos e de conservação de espécies.

\subsection{O Cerrado}

O Cerrado é o segundo bioma de maior extensão (Ratter et al. 1997) e o segundo mais ameaçado do Brasil (Myers et al. 2000). Este bioma está situado na região central do Brasil e sua área de ocorrência era de aproximadamente $2.000 .000 \mathrm{~km}^{2}$ no início da ocupação européia. Hoje, estima-se que mais de $50 \%$ desta área já tenha sido alterada (Carvalho et al., 2009). A ocupação humana dos últimos remanescentes tem se intensificado recentemente devido à expansão da agricultura mecanizada de monoculturas (Frederico, 2010, Spera et al. 2016). O Cerrado possui uma maior heterogeneidade de ambientes em escala da paisagem que os biomas mais ricos em biodiversidade que ocorrem no Brasil (Mata Atlântica e Floresta Amazônica). Esta heterogeneidade acontece por que o Cerrado é formado por um mosaico de vários tipos de vegetação ou de fitofisionomias (p. ex. campos, savanas, florestas estacionais e formações ripárias e/ou associadas a corpos d'água). Esta heterogeneidade ambiental influencia tanto a diversidade quanto a estrutura e dinâmica das comunidades de organismos que ali vivem (Nogueira et al. 2011; da Silva and Bates, 2002). Apesar da importância e relevância da diversidade de plantas (Simon et al. 2009) e de animais do Cerrado em nível global (Myers et al., 2000), a conservação do Cerrado ainda é negligenciada em relação aos outros biomas brasileiros (Klink and MAchado, 2005). Trabalhos biológicos e ecológicos têm aumentado significativamente nos últimos anos, porém a maioria dos trabalhos no Cerrado ainda é focado nas características da flora e também na produção agrícola na área de ocorrência do bioma (Borges et al. 
2015).

\subsection{Objetivo desta tese}

Assim, vista a importância da estrutura da vegetação para a determinação da diversidade de comunidades de aves e o recente desenvolvimento de ferramentas analíticas robustas capazes de representar adequadamente os parâmetros desta relação, o objetivo do presente trabalho é avaliar a relação entre diversidade de aves e estrutura da vegetação no Cerrado. Nossa abordagem consistiu de duas análises distintas, que irão gerar manuscritos a serem submetidos e que juntos pretendem prover um panorama inédito do efeito da estrutura da vegetação sobre a riqueza de espécies de aves no Cerrado. Inicialmente, será feita uma análise de estudos publicados na literatura sobre a diversidade de aves em tipos fisionômicos do bioma Cerrado. Posteriormente também será feita a análise dos resultados de um estudo observacional que considerou os efeitos da detectabilidade imperfeita sobre as estimativas da diversidade de aves em um mosaico vegetacional no Cerrado. Espera-se que, assim como em outros biomas e formações florestais ao redor do globo, a diversidade de aves seja maior em áreas com maior complexidade de estrutura da vegetação. Espera-se também que a estrutura da vegetação irá afetar a detectabilidade das espécies e portanto, as estimativas de diversidade tomadas das comunidades. 
Capítulo 2

Bird diversity and vegetation structure relationship in Cerrado hotspot, Brazil: Can different sampling methods affect our view of ecological patterns? 


\section{ABSTRACT}

Aim: Analyse the relation of bird species diversity and vegetation physiognomy considering the influence of different sampling methods in describe this relation.

Location: Main region of Brazilian Cerrado savanna hot spot. We search secondary data in scientific literature of the world and in Brazil, including scientific papers, Master thesis and Ph.D dissertations and regionally important biological publications.

Methods: We compiled data about bird species richness surveyed in a gradient of vegetation structure formed by different Cerrado physignomies (grasslands, savannas and forests). These studies also were performed using three different bird sampling methods: point counts, transects and capture by mist nets. As these data were collected at different localities and were published in different studies by different authors, we used a generalized linear mixed model approach (GLMM) to consider the random variation of the species richness due to these variables. We used a model selection approach and selected the best models by Akaike information criterion (AIC).

Results: The best model to predict the Cerrado bird diversity was the one that includes the vegetation physiognomy, the sampling method and interaction among them as independent variables. Also, the regions where the samples were taken and the publication where the data were obtained influenced the variance of bird species richness estimation for each physiognomy and sampling method.

Main conclusions: We observed that the influence of vegetation structure in methods efficiency can potentially affect the results and the conclusions of the studies. This fact could biased our view of this ecological pattern, if the sampling effort has not been sufficient to reach the assymptote of bird richness accumulation curve of each vegetation type. We suggest that future studies focused in understand ecological patterns and/or in survey bird diversity to conservation and monitoring programs, consider the effects of detection probabilities to generate reliable estimations about 
highly diverse and threatened tropical areas.

Keywords: aves, savanna, species richness, habitat structure, conservation, detectability 


\subsection{INTRODUCTION}

Vegetation structural heterogeneity is one of the most important environmental drivers of birds diversity (Tews et al. 2004). This relationship between bird diversity and vegetation structure can be predicted by the "Vegetation Structure Hypothesis" (Kissling et al., 2008) and more generally by the "Resource Specialization Hypothesis" (Srivastava and Lawton, 1998; Hurlbert, 2004). The ecological mechanism behind these two hypotheses is that the greater availability and diversity of resources in more complex habitats allows more species with different niches to coexist (Srivastava and Lawton, 1998). Several studies had emphasized that vegetation structure is strongly correlated to the number of species recorded in a given habitat (Wilson, 1974; Cody, 1985). In the early 1960's, R. H. MacArthur had already observed that bird species diversity in eastern US forests was strongly related to vertical vegetation profile (MacArthur and MacArthur, 1961; MacArthur et al. 1962). This positive relationship of number of species and structural diversity of vegetation was also noted by Wiens and Rotenberry (1981) for shrubsteppe bird communities in western North American Great Basin. Recently, Hurlbert (2004) showed that number of North American bird species was greater in more complex and forested habitats than in open ones, even with both habitats presenting the same productivity. Then, this result reinforces the role of vegetation structure per se as an important factor influencing the number of bird species in temperate regions.

Unfortunately, this relation of bird diversity and vegetation structure was little explored at tropical regions. The few published studies were mainly focused in tropical rain forests. For instance, Terborgh (1977) found a positive correlation of bird diversity and foliage height profile in elevational gradients of peruvian rain forests. More recently and also in an altitudinal gradient in Peru, Jankowski et al. (2013) also observed that bird species richness increase with forest canopy height. On the other hand, other types of vegetation vastly distributed in the tropics, such as woodlands and grasslands, are rarely mentioned, specially those vegetations that occurs in Australia, Africa and South America (Tews et al. 2004). In a context of human impacts and disturbances on vegetation in Australia, Kutt 
and Martin (2010) showed a negative influence of woodland thinning and clearing on bird diversity. Also, in savannas of southern Africa, vegetation alterations due to grazing and tree removal also influenced both the bird species richness and abundance (Seymour and Dean, 2010). Using woody plant and bird distribution maps of Kenya, Kissling et al. (2008) also found evidence that the vegetation structure is positively related to the number of bird species. However, as other results in the same region presented no evidence on the bird diversity-vegetation structure relation (e.g Kissling et al. (2007), these authors suggested more studies in this topic to improve the knowledge on the role of vegetation structure for tropical woodland bird communities diversity.

Vegetation structure varies dramatically even in undisturbed areas within the woodland vegetations, notably in the neotropical savannas. "Cerrado" vegetation -the Brazilian savanna- is the most extense savanna of South America, and encompasses a wide range of phytophysiognomies, from open fields to seasonal forests. This habitat heterogeneity results in a marked gradient of vegetation structure. Even though, the few studies available that were concerned with the relationship of avifauna and vegetation structure in Cerrado are not conclusive. This happens because some of these studies provided only a qualitative description of bird diversity among phytophysiognomies (Tubelis and Cavalcanti, 2001; Pacheco and Olmos, 2006; Motta-Junior et al. 2008), while others studies showed an increase of bird diversity with vegetation structure (Pacheco and Olmos, 2006, Fieker, 2012 ) and some showed even a negative relationship among these two variables (Silva, 2004; Piratelli and Blake, 2006; Rodrigues and Faria, 2007). Nevertheless, a confounding factor among these studies is that they used different sampling methods to address the relationship of bird diversity and vegetation structure. This is a important factor to consider because different sampling methods may present biases, which can affect the detectability of species and consequently, of the diversity patterns (Blake and Loiselle, 2001). In this sense, the evaluation of bird diversity and vegetation structure relationship can be potentially problematic if the census methods are sensitive to vegetation characteristics Bonter et al., 2008). Thus, a crucial step to obtain reliable estimates and answer ecological questions is to know and understand the effectiveness and limitations of sampling methods in 
the characterization of the properties of biological assemblages (Elphick, 2008).

In bird community studies, several methods were developed and had been applied depending on the research focus, financial and technical support and even preferences of each researcher. The three most used methods to sample bird communities are transects, point counts and capture by mist nets (Bibby et al., 1992). Point counts method depends on visual and auditive contacts with birds while the observer stays in the same spot during the sampling time interval. It is indicated to sample bird communities in heterogeneous landscapes, because it is easier to spatially distribute point counts in the landscape unities and also it is easier to achieve statistical independence among samples (Bibby et al., 1992). The transect method also consists in registering bird species visually and/or auditivelly, but the records are made with the observer travelling along a path during a predetermined time and space interval. This method is broadly used because it allows the observer to cover larger sampling areas with less time effort and allows accurate estimates of bird species richness at a site or region (Verner and Ritter, 1985). Finally, mist-netting consists in capture birds in nets opened usually at 0-3 m high. This method is more expensive and time consuming than point count or transect methods, but the possibility of capture and marking individuals allows the observer to gather population and community parameters with greater accuracy (Bibby et al. 1992). Although each of these methods have their advantages, they can present some particular biases that could affect the efficiency (i.e. number of registered species by unity of temporal sampling effort) of each one and could alter the conclusions of the studies as well. For example, point counts can yield undersampled estimations of bird diversity by the presence and density of vegetation around the observation point (Bibby et al., 1992). Line transects can accumulate less records than point counts by the noise produced during the observer movement and can cause the observer distraction and evasion of birds from the transect vicinity (Roberts and Schnell 2006). In turn, mist nets rarely span from canopy to the ground and it has been criticized for undersample bird communities, by the loss of specialists of uncovered vegetation strata (Bonter et al. 2008). Therefore, it is important not just to know how sampling method influences diversity estimation, but also to consider their effects to adequately represent the 
properties of biological systems. The neglect of this sampling biases can lead to superficial and misguided interpretations of the study results, which may have serious consequences for the understanding and conservation of biodiversity. This problem could be even more important in the tropics, which includes very diverse and threatened regions that are still poorly understood.

Our aim is to analyse the relationship of bird diversity and vegetation structure across the natural gradient of vegetation structure in the Brazilian savanna. To obtain the data, we built a comprehensive dataset of studies that surveyed bird diversity in different vegetation types of Cerrado biome. As our view of this relationship could be affected by potential biases of the avian census methods, we also analyse their effects on the estimation of bird diversity-vegetation structure relationship. We expected that bird species richness would be higher in more complex and forested vegetation than in less complex ones. Also, we believe that methods that combine visual and auditive detections and effectively cover larger areas will record more bird species and diversity. We believe that the knowledge of the vegetation structure and bird diversity relationship and the possible influence of sampling methods will greatly improve the understanding of ecological patterns of bird communities and can help to develop conservation and monitoring programs to Cerrado communities as well.

\subsection{METHODS}

\section{Study region}

Cerrado domain is located in the central portion of South America, mainly in Brazil's territory and it is the second largest biome in this country. It mainly occurs on dystrophic, aluminium-rich and well drained soils. As other savannas in the world, the typical vegetation includes from open and/or dense grasslands (e.g. "campo limpo" and "campo sujo", respectively), sparse and dense savannas ("campo cerrado" e "cerrado sensu stricto" woodlands), to closed-canopy woodlands ("cerradão" woodlands and semi and/or deciduous dry forests) and evergreen forested vegetation enclaves ( "mata de galeria" and "mata 
ciliar" riverine forests). However, Cerrado sensu lato vegetation definition includes only grasslands, savannas and "cerradão" seasonal dry forests, by the major floristic similarity of floras among these phytophysyognomies (Coutinho, 1978; Oliveira-Filho and Ratter, 2002). The occurrence of these different vegetation phytophysyionomies is determined mainly by gradients of soils fertility and depth, water saturation and also by occurrence of fire (Ratter et al. 1997). The influence of these factors results in mosaics of vegetation patches, but most Cerrado vegetation (about 3/4 of total Cerrado area) consists of savanna vegetation (including open and dense grasslands) and the remainder area is covered by dry forests and intermediate types between these two (da Silva and Bates, 2002). Besides this great vegetation and habitat heterogeneity, the Cerrado biome also bears great diversity and high rates of endemisms of plants and animals da Silva and Bates, 2002, Simon et al. 2009 Nogueira et al., 2011). About 840 bird species are found in Cerrado region (Marini and Garcia, 2005), which is almost $50 \%$ of brazilian avifauna. Among those, approximately 4 $\%$ are endemic bird species (da Silva and Bates, 2002) and almost $12 \%$ are classified as globally threatened (Marini and Garcia, 2005). Despite the big extension and biological diversity in the Cerrado region, some authors estimated that between 40 and $60 \%$ of the total area of the Cerrado has already been converted by human land uses Carvalho et al. (2009), but other suggested that the loss natural cover could reach $80 \%$, putting Cerrado as one of the global hotspots of biodiversity (Myers et al. 2000).

\section{Secondary data search}

We searched for Cerrado bird community studies in four main sources of data: indexed scientific literature databases, master and $\mathrm{PhD}$ thesis databases of brazilian Universities, regional important non-indexed publications and also for governmental agencies reports (e.g. management plans of protected areas, environmental assessments). For published indexed papers, we looked at Web of Science, Scopus and Scielo databases (hereafter WoS, Sco and Sci, respectively). They are the three most used databases for biological scientific literature in Brazil and cover periods from 1900, 1985 and 2000 to present, respectively. We inspect these bases from November to December 2013, to find studies that contained 
the keywords in document fields specified by us (Table A.1, Appendix A.1). In the WoS and Sco databases, because the wide covering and quantity of studies in them, we searched for keywords related with our research subject only in study titles, abstracts and keywords fields. In Sci database, we looked for keywords in all indices and search fields, because the volume of data to trial is manageable and chances of find studies of our interest is greater than in the other two databases. During January-March 2014 we searched for master thesis and Ph.D dissertations in the Brazilian graduate studies agency (CAPES) database (http://bancodeteses.capes.gov.br/), which includes the majority of graduation studies produced in Brazil since 1985. Also, we searched in biology, zoology and/or ecology graduation courses databases of universities located inside the main Cerrado region (Table A.2. Appendix A.1), to find older documents not included in the CAPES base. In these databases, we looked for all studies that included both "aves" ("birds" in portuguese) and "cerrado" keywords in their abstracts. We reviewed all the content of editions and volumes of regional non-indexed publications in avian, ecological and/or biological research in Brazil and South America, from 1971 until today (Table A.3. Appendix A.1). We visited the available volumes in publication websites and the others not available in these online databases were consulted in the Instituto de Biociências' library collection, at University of São Paulo, Brazil. Additionally, during November 2013 and July 2014 period, we made

a non-sistematic search on internet using Google search tool site using "cerrado", "bird" and "vegetation" as keywords. We used this tool to find additional studies not included in the sistematic search and others cited in other study compilations (Accordi et al., 2003 , 2005, 005a; Borges, 2008; Morandini, 2013). Finally, during 2015 we review our findings searching for citations of other studies and also asked for recognized authors and researchers of the area for missing or additional works or compilations that could be interesting to our subject.

Database construction and inclusion criteria

After a first inspection of all study titles and abstracts found in our searches, we rejected the studies not related with Cerrado birds and/or Cerrado region. We consid- 
ered only studies performed inside the main Brazilian Cerrado region, excluding others tropical "savanna" vegetations outside Brazil (e.g., African and Australian savannas and Venezuelan Llaños), inside Pantanal wetlands or inside Amazonia region ("campinaranas" or Amazonian savanna enclaves). By great historical and geographical differences of these vegetation types in relation of the main Cerrado region vegetation, the inclusion of these studies in our analyses could introduce undesirable variation in our data set. After this first step, we created a spreadsheet to tabulate information from 175 potentially interesting studies. These studies were then screened based on four sequential criteria:

Surveys of Cerrado bird community: We classify all of the 175 studies as surveys of the entire bird community or not. We reject textbooks and study compilations that aimed to describe bird diversity of some region or place, as well as theoretical studies about conservation and distribution patterns of Cerrado birds. Additionally, we rejected reviews and studies about foraging, reproduction and diversity of a single or few taxa (usually a single family), foraging guilds (e.g. insectivores) or studies of mixed flocks of birds. By applying this criterion, we selected 123 studies that aimed to survey the entire diurnal bird community of a site, of a region or that presented data of several field surveys in main Cerrado region;

Surveys of typical Cerrado sensu lato phytophisiognomies: Among the 123 studies selected through the application of the first criterion, we exclude those studies performed in plantations of exotic or native species or in very anthropified sites (i.e. habitat patches smaller than $30 \mathrm{ha}$ ). We also rejected surveys on riparian vegetation or in areas subject to flooding or waterlogging (e.g. seasonal flooded grasslands) during the most duration of the year. Surveys in decidual or semidecidual forests, even occuring inside the main Cerrado region, were also excluded of our analyses. We considered that these sites may present great influences of adjacent habitats in birds assemblages of sampled sites and they also may have different plant species composition in relation to Cerrado sensu lato phytophysiognomies. Then, we selected a subset of 99 bird inventories that were performed in typical phytophysiognomies of 
Cerrado sensu lato, which must be clearly classified by the authors of each study.

Description of sampling method and sampling effort: We included only inventories that used point counts, transects and capture by mist nets to survey birds and contained clear informations about the sampling methods and the sampling effort employed using each one, as well as the sampling effort employed in each sampled site. As sampling methods and sampling effort have direct relation with estimation of bird diversity, both information were used in our analysis to reduce the residual error in it. We selected 70 studies after the application of this criterion.

Description of bird community diversity per site: We needed that authors must present the number of species or a list of species by each location. We define as a independent site in our analysis the sampling unities presented by the authors, with a measure of bird diversity and the methods and effort used to sampling it. The application of this criterion resulted in a subset of 55 studies.

After the application of our criteria, we inspected the remaining 55 studies to extract the information we needed. In this step, we excluded six studies that shared data with other more complete ones. Also, we rejected other 13 studies that used Rapid Ecological Assessments survey protocol(RAE)(e.g., all governmental agencies reports and some bird inventories), because we considered this methodology indicated to generate basic knowledge about the diversity of a site or region, and could not precisely represent the species versus vegetation structure relation. Finally, we did not locate 14 of the remaining 36 studies cited during our search. Then, at the end of studies inspection, we selected 22 studies, which sampled 72 sites distributed in the core and peripheral areas of Cerrado. All these sites are located at southeast, western, central and north regions of Brazil (Figure 2.1) and are described in detail in supplementary material (Table A.4. Appendix A.2. Ideally, all studies should have sampled all phytophysiognomies using the three different methods. However, we also considered studies that sampled only one phytophysiognomy and using just one method, to maximize our sample and because our statistical methods were robust enough to lead with unbalanced designs (see Statistical Analysis section below). 


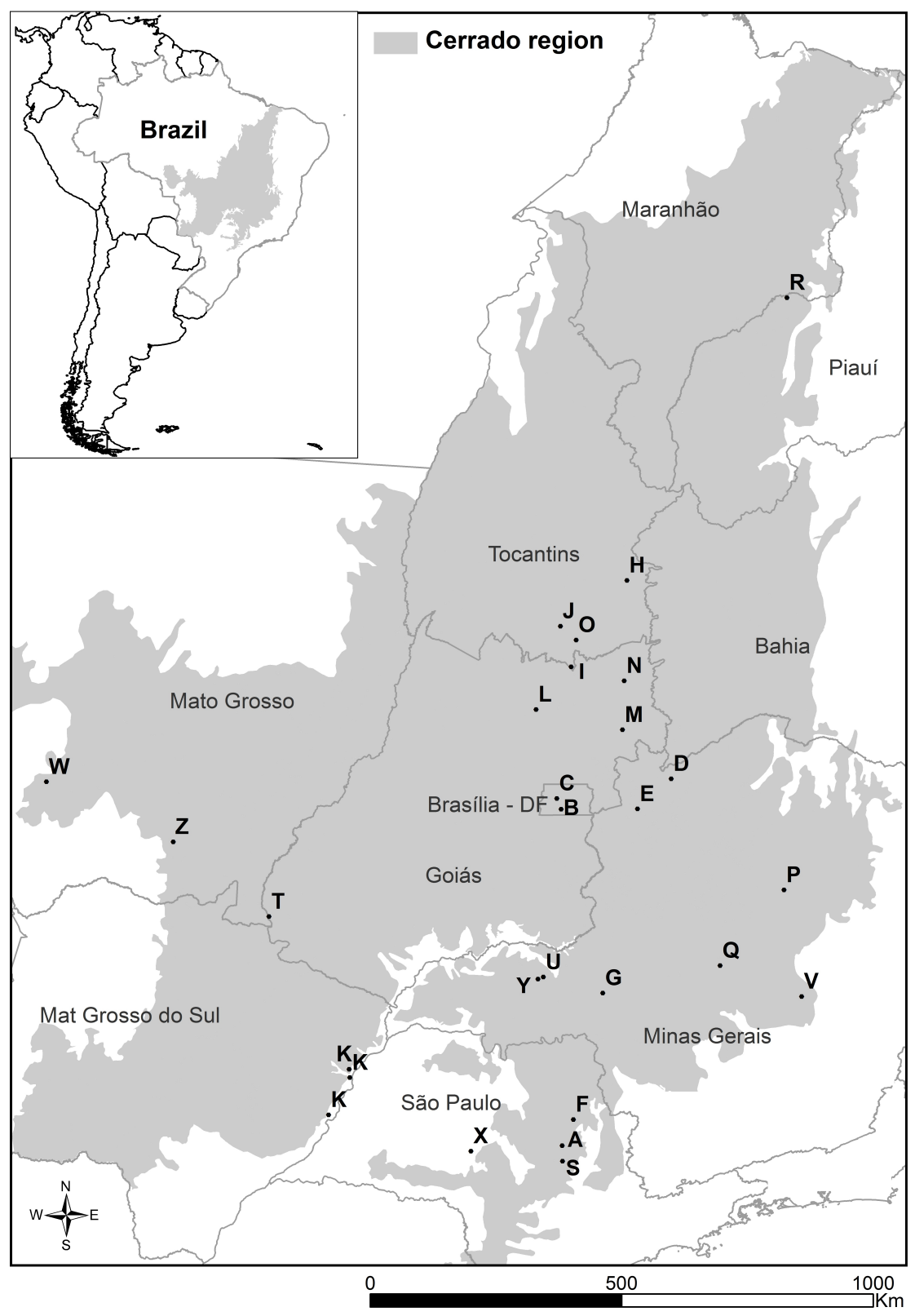

Figure 2.1: Map of South America and Brazil, showing the original spatial distribution of the Cerrado region. In the amplified view, brazilian states names are showed and letters indicates the 26 sampled regions used in our analyses. Regions and sampled sites are described in Table A.4. Appendix A.2 


\section{Response variable}

We used as response variable the species richness in each site, which is obtained by the number of species detected in the site survey. This measure was also divided by the log of sampling effort in each site, which allowed us standardize the number of species by effort unity. This resultant response variable can be interpreted as the number of species added in each log of sampling hours and have close resemblance with the increment of species at the initially steppest growth in species accumulation curves Gotelli and Colwell, 2001). In the cases where the authors presented a list of species sampled by each site (59 of 72 sites, $81 \%$ of cases), we calculated the number of species considering only diurnal species, because nocturnal species (e.g. Tytonidae, Strigidae, Nyctibidae and Caprimulgidae families) are registered almost eventually during standard diurnal bird community surveys and probably were undersampled in them. We also did not considered in the number of species unidentified taxa at the species level (e.g. Elaenia sp.) and we considered both boreal and austral migratory species as part of the species pool of the site. The sampling effort presented by the authors were obtained of each study methods by collecting the information in the text or by calculating the total hours of sampling by number of samples and number of temporal replicates. Point counts were sampled as periods of 10, 15 and 20 minutes, and varied from to 3 to 30 points in each sample site. Transects also varied in time period and in length (from 0.5 to $1.5 \mathrm{~km}$ ) and mist nets oppened by sampling session varied from two to 25 standard nets (12 m length and between 2.0 and $3.0 \mathrm{~m}$ of heigth and 36 and $61 \mathrm{~mm}$ mesh size). As the number of nets varied greatly and the number of bird species and individuals catched in one net oppened is very low, we had to rescale the net sampling effort as 10 net/hour. As both sampling effort and number of species varied greatly among sites (ranging 2-601 h and 6-201, respectively) and are non-linearly related, the use of a logarithm scale best met the assumptions of linear analysis, such as normal distribution of errors and homogeneity of variances. To assure the validity of this standardization we checked the linear relationship between the logarithm of the number of recorded species and the logarithm of effort time (Figure A.1. Appendix 


\section{Independent variables}

We summarized the types of cerrado vegetation reported by the authors in three wide classes in which all reported subtypes can be securely distinguished (Table A.5, Appendix A.2). A complete description of the main types of cerrado considered here can be found at Goodland (1971); Ribeiro and Walter (1998) and more simplified in da Silva and Bates (2002). These three wide phitophysiognomy classes were used as a categorical variable in the analysis. The first class is Grasslands, that are phytophysiognomies with greater predominance of grasses, exposed soil or exposed rocks and also few sparse shrubs and small trees. The second class is Savannas, where the shrubs, treelets and some trees of between 3 and $8 \mathrm{~m}$ forms a distinct strata, as important as the herbaceous layer. The third and last class is Forests, which include the "cerradão" dry forests. In these physiognomy there is a continuous and dense tree canopy of 8-15 m high, grasses and forbs are sparse and the density of shrubs is lower than in savanna and grasslands vegetation types.

In studies revised by us, three methods of bird sampling were used: point counts, transects and capture by mist nets. Then, we also used information about the sampling method employed to survey bird community provided by the authors in each study.

As many surveyed sites were in the same geographical region and some were visited concomitantly during the preparation of the studies, these surveys can not be considered as completely independent replicates. Then, we considered as independent random variables the regions where the data were collected, the authors that collected them and the study where the data was published, which summarizes the effects of the sampled region, the observer effect and other study's particularities. For this purpose, we considered as samples of the same sampled region all samples taken within the same continuous natural area (e.g. Brasília Natural Park), or those located closer than $2 \mathrm{~km}$ from other sampled areas. The senior author of each study was considered as the main collector of the data and the author names and publication year was used to identify each publication. 


\section{Statistical analysis and models construction}

We used generalized linear mixed models analysis (GLMM), which is an indicated tool to analyse data where part of the variation among sampling units is related to known parameters that are not related with the objectives of the study (random effects)(Bolker et al., 2009). These models uses a Poisson error distribution, that is indicated to model counting variables and we included the logarithm of sampling effort as an offset in the model, to standardize at 1 the effect of the sampling effort on species richness, as we had already mentioned. We modelled the relationship of dependent variable, recorded number of species per hour in Cerrado bird communities, with explanatory variables, phytophysiognomy and sampling method. Also, we tested if the addition and interaction of the effects of the two explanatory variables could be important to describe the variation of bird species richness in samples. The addition effects hypothesis is justified by the effects of both variables could present on species richness, but these effects are independent and the total effect is obtained by the sum of both effects. In the case of interaction among variables effects, the effect of vegetation structure on species richness will depend on the sampling method used and vice versa. Also, as cited in the independent variables section above, we also consider the effects of region, authors and publication as random variables, to modelling variance in the model predicted effects. The models construction and statistical tests followed the Zuur et al. (2009) protocol to analyse nested and hierarchical data. First, we identified the best random variable structure of the model, including all the important fixed effects in models and testing which of the random variables is/are more important to represent our data. The selection of the best random effects structure were made comparing the models fit by the AICc model selection criterion (see below). We constructed 12 GLMM models with the same fixed structure to test which of the random variables structure presented better fit of the data. We built mixed models with one or more variables acting as intercept random effects and other models with variables acting as intercept and slope random effects (Table A.6. Appendix A.3). Among those, two were chosen as best models by our model selection criterion: one that included the random intercept effects of sampling region and study author and other that had sampling region 
and publication as random intercept effects (Table A.6. Appendix A.3). We chosen the last one as the best random effects structure because we found only two studies performed by the same author. For this reason, we think our data did not present replicates enough to support an author random effect. After this step, we selected the best fixed effect variables, using the best random effect structure selected earlier. The models evaluated were a nested set that encompasses the interaction between sampling method and vegetation type, the additive effects of the these two variables and also each effect separately. We also included a null model in the model selection, to test the hypothesis that the dependent variable is constant or unrelated to the variables. In this step, models also were selected using the Akaike Information Criterion (AIC), with a correction of this index to small samples (AICc). The model with smaller AICc was considered the most plausible description of the data and any other that presented differences of model AICcs $(\Delta \mathrm{AICc})$ lesser than two were considered equally plausible. All the analyses were made in the R software, using "glmer" function of lme4 package (Bates et al., 2014). The differences among model AICcs ( $\triangle \mathrm{AICc})$ was computed by "AICctab" function, of bbmle $\mathrm{R}$ package (Bolker and Team, 2016). Best model(s) were inspected and validated by the analysis of residuals distribution for each exploratory variables and by the quantile-quantile plot, to visually check the residuals fit to a normal distribution. By these analyses, no clear evidence of non-normality and heterocedasticity associated to fixed effects was found, which support our choice for this analysis (Figure A.2, Appendix A.3). To examine our results, we used the parameter values obtained after the fit of the best model to simulate 10000 similar data sets. We fitted again the model on these data and calculated the mean predicted richness and mean confidence intervals of fixed and random effects in each combination of vegetation type and census method.

\subsection{RESULTS}

The most plausible model included the interactive effects of phytophysiognomy and sampling method variables (Table 2.1). 
Table 2.1 - Comparison of linear mixed-effects models that describe the relationship of bird species richness with phytophysiognomy and bird sampling methods. The column Model fixed effects shows the independent variable(s) that each model include, the Random effects column shows the variables included as random effects. The column AICc shows the values of model's Akaike Information Criterion, corrected for small samples. The column $\triangle A I C c$ shows the relative distance of each model to the best model ( $\mathrm{AICc}=0$ ). The last two columns, $d f$ and Weights show the degrees of freedom (number of estimated parameters) and weights (conditional probability of each model being the best one) of each of the models. Variables legend: Phy = Vegetation phytophysiognomy; Met = Sampling method, Phy:Met = interaction among Vegetation phytophysiognomy and Sampling Method effects; $1 \mid$ Reg = random intercept effect of sampled region; $1 \mid \mathrm{Pub}=$ random intercept effect of publication.

\begin{tabular}{lcccc}
\hline Model Fixed effects & Random effects & AICc & $\Delta$ AICc & df \\
\hline Phy + Met + Phy:Met & $1 \mid$ Reg $+1 \mid$ Pub & 670.63 & 0 & 11 \\
Phy + Met & $1|\operatorname{Reg}+1|$ Pub & 689.19 & 18.55 & 7 \\
Met & $1|\operatorname{Reg}+1|$ Pub & 695.8 & 25.16 & 5 \\
Phy & $1|\operatorname{Reg}+1|$ Pub & 1714.56 & 1043.92 & 5 \\
Constant & $1|\operatorname{Reg}+1|$ Pub & 1721.24 & 1050.61 & 3 \\
\hline
\end{tabular}

All other models, including the null effects model, presented $\triangle \mathrm{AICc}$ values higher than 10, which points to low predictive power of these models against the best model (Table 2.1.

The interaction between phytophysiognomy and sampling method indicates that the efficiency of different sampling methods to sample species can change among phytophysiognomies. Additionally, the random effect variables, sampled region and publication, described the variation of parameter estimations with a standard deviation of 1.33 and 2.41 species per sampling hour, respectively. This means that the value of species initially expected to occur in each physiognomy using a specific method can vary around 3.7 species per hour, only by the sum of the expected variation due to sampled regions and publications singularities.

The model fixed effects predicted that point counts records a mean of more than seven species per hour in grasslands. The model also predicted that savannas phytophysiognomies sampled by point counts records a mean of almost 11 species per effort hour, which represented an increase in the number of species per hour of around $40 \%$ in relation to grasslands. Likewise, the model predicted that point counts sample a mean of two species per hour of effort in forests, which is only $30 \%$ of the estimated for grasslands using this method (Table 2.2). The inspection of the confidence intervals of these parameters shows 
that the estimated mean number of species per effort hour in forests is strongly lower than in savanna and grasslands, but these two vegetation types could not present any differences in mean number of species sampled per hour. By the transect method, the estimated mean number of species in grasslands was of around 1.5 species per hour. Similarly, savannas sampled by the transect method accumulates a mean of 1.4 species per effort hour and forests presents a mean of around 1.5 species per hour of sample, which was the highest number of species per effort hour using transects method (Table 2.2). As the small differences among mean fixed effects suggests, confidence intervals of these parameters indicates that the three vegetation types sampled by transects can not differ in number of species sampled per hour. Finally, mist net method samples a mean of around of 0.7 species per hour in grasslands, while the mean number of species by effort hour in savannas and forests are about 0.6 and 0.4 , respectively. Again, by the inspection of coefficients confidence intervals, we also could not expect any differences in sampled species richness on these three vegetation physiognomies using the mist net method.

The predicted species richness by point count census method is greater for all phytophysiognomies, in comparison with the other two methods. However, this method predicted lower species richness in forests than in savannas and grasslands (Figure 2.2). On the other hand, transect method presented intermediate predicted values of species richness in relation to other two methods, but was the unique census method that showed a trend of increasing predicted species richness with the increase of vegetation structure (Figure 2.2). Mist nets presented the lowest predicted species richness per hour for all phytophysiognomies and also presented a slightly trend of decrease in species richness estimations with the increase of vegetation structure (Figure 2.2).

\subsection{DISCUSSION}

Our analyses showed that bird species richness in Cerrado are related to phytophysignomies, to sampling methods and by interactive effects between these two variables. Also, the number of species recorded varied depending on the region where the sample was taken 
Table 2.2 - Summary of best statistical GLMM model fitted to our data. Table shows model coefficients with their confidence intervals, number of total observations, number of levels and estimated variance for each of the random variables included in the model.

\begin{tabular}{lc}
\hline Model coefficients & Values [IC's] \\
\hline Intercept & $2.00^{*}$ \\
Method.mist net & $1.53 ; 2.48]$ \\
& $-2.32^{*}$ \\
Method.transect & $-2.76 ;-1.90]$ \\
& $-1.62^{*}$ \\
Phyto.forest & {$[-1.98 ;-1.27]$} \\
& -1.22 \\
Phyto.savanna & {$[-3.21 ; 0.76]$} \\
& $0.36^{*}$ \\
Method.mist net:Phyto.forest & {$[0.22 ; 0.50]$} \\
& 0.62 \\
Method.transect:Phyto.forest & {$[-1.41 ; 2.65]$} \\
& 1.28 \\
Method.mist net:Phyto.savanna & $-0.71 ; 3.28]$ \\
& {$[-0.96 ;-0.19]$} \\
Method.transect:Phyto.savanna & $-0.37^{*}$ \\
& {$[-0.61 ;-0.14]$} \\
\hline Num. obs. & 72 \\
Num. groups: region & 26 \\
Num. groups: publication & 22 \\
Variance: regiao.(Intercept) & 0.08 \\
Variance: autor.ano.(Intercept) & 0.79 \\
\hline
\end{tabular}

* 0 outside the confidence interval 


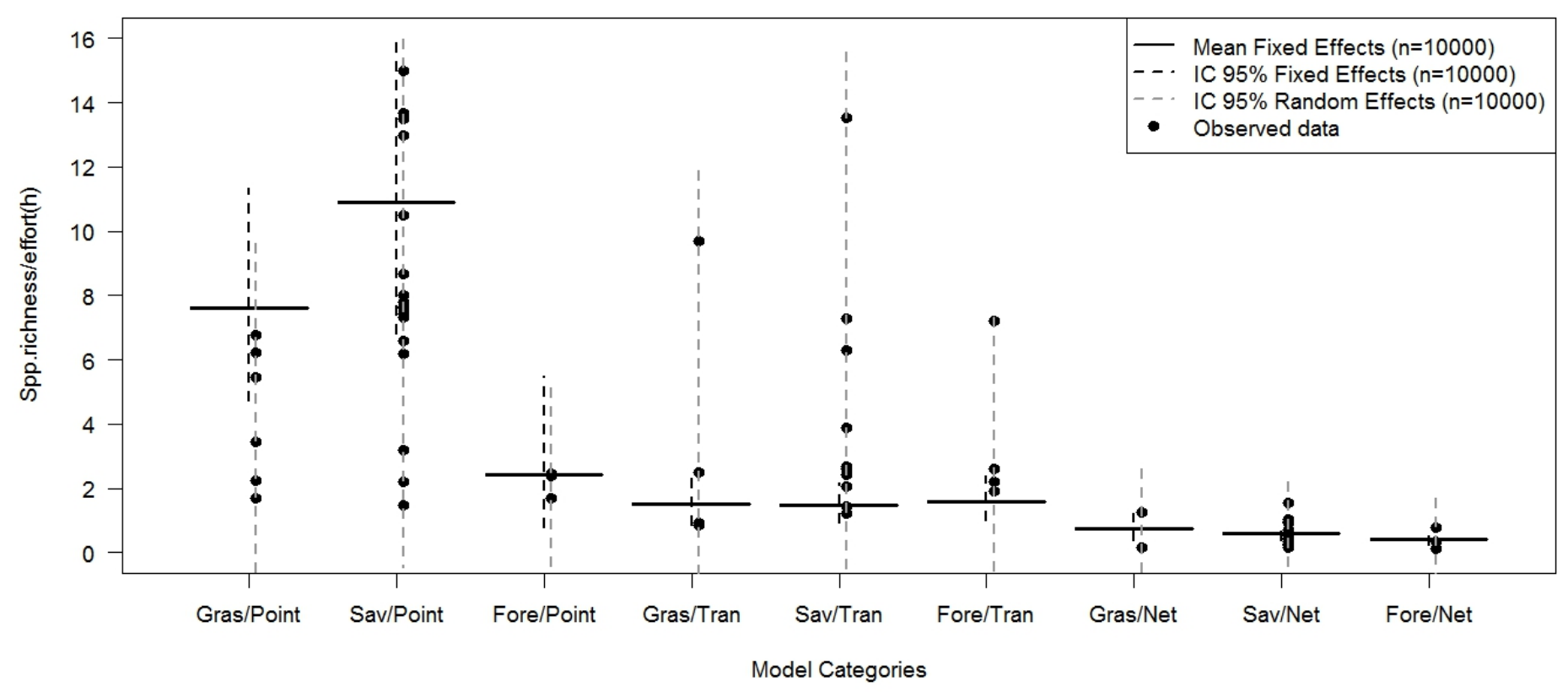

Figure 2.2: Predicted number of species per unity of effort for combinations of each independent variable levels. Solid lines are predicted number of species by fixed effects, dashed lines are the standard deviation around fixed effects predictions, estimated to sampled regions and publication random effects and points are the observed values of Cerrado bird diversity for each combination of vegetation physiognomies and census methods.

and also varied by influences of the particularities of each study design, accounted as random effects. These results predicted by the fixed effects are not conclusive to reveal the well known positive relationship between bird diversity and vegetation structure Wiens and Rotenberry, 1981, Cody, 1985, Hurlbert, 2004, Kissling et al., 2008). However, they pointed to the influence of census methods on quantifying the bird diversity (Bibby et al. 1992; Blake and Loiselle, 2001; Bonter et al., 2008). The interaction among census methods and vegetation structure effects suggests different effects of phytophysiognomy in the sampling efficiency of each method to register species. Hence, we can expect that census methods can influence our view of the relationship between bird species richness and vegetation structure (Mackenzie et al. 2006).

The main part of studies about Cerrado bird communities that we found did not address the relationship between bird diversity and vegetation structure and physiognomy directly (Motta Jr. 1990; Lins, 1994, Antas, 1999; Abreu, 2000, Curcino et al., 2007, Braz, 2008, Sendoda, 2009, Tolesano-Pascoli et al., 2010; Cavarzere, 2013; Pascoal et al., 2013). Other 
studies were focused in descriptions of bird diversity in diverse and undersampled regions Almeida, 2002, Pacheco and Olmos, 2006; Martins, 2007; Costa and Rodrigues, 2012, Olmos and Brito, 2007) and few ones had investigated quantitatively the relation of bird diversity with physiognomy in a local scale. (Tubelis and Cavalcanti, 2001; Silva, 2004, Piratelli and Blake, 2006; Rodrigues and Faria, 2007; Motta-Junior et al., 2008; Valadão, 2012; Posso et al., 2013, Fieker, 2012). Our study presented a view of this question for the entire biome and also showed how the choice and use of different methods could affect the conclusions of studies on the bird diversity-vegetation structure relationship.

One advantage of the use of mixed effects models is to separately quantify different sources of heterogeneity in the data. In our study, the use of sampled region and publication as random effect variables allow us to incorpore very different studies in our analysis and measure the variance included in data by these two variables. The heterogeneity between studies was evident by the comparison of the variance due to publication with the estimated variance among sampled regions. The estimated variance among papers was almost two times higher than the estimated variance among regions, which we think will strongly influence our results due to climatic, geographical and ecological singularities of each region. We believe that some of this great variance found among studies could be due to factors as number of observers and their survey experience, number of points, number and size of nets oppened, number and extension of transects, radius census definition and another factors that could introduce heterogeneity in our samples. All these factors, besides basic information about the diversity surveyed per site and per sampling method, sampling effort and sampling geographical location, were not always clearly described in the studies we compiled. For these reasons, we recommended that future studies that aimed to survey bird communities in Cerrado and in other unknown and threatened regions should include these information of study design in the publications whenever as possible, to also allow the use of these data in future studies.

Since the beginning of bird ecology studies, the structure of vegetation has been viewed as one of the most important factors affecting bird community diversity (MacArthur and MacArthur, 1961; MacArthur et al., 1962, Wiens and Rotenberry, 1981). This positive 
relationship is explained by the effect of the vegetation on the number of spots and microhabitats to nest, sing, shelter and feed, decreasing the competition and promoting coexistence of more species (Wiens and Rotenberry, 1981). This hypothesis, called as "Resource Specialization Hypothesis", is invoked as one of the explanations of why the number of species is greater in tropical forests than in temperate ones (Orians, 1969). More specifically, the derived "Vegetation Structure Hypothesis" has been considered as a explanation by the increase of bird diversity with increase of structural complexity of vegetation (Hurlbert, 2004; Kissling et al., 2008). This relationship of vegetation structure and bird diversity was also tested and corroborated in Australia (Price et al. 2013) and Africa (Skowno and Bond, 2003) tropical savannas. However, the evidences for South American savannas are still inconclusive, mainly by the confounding effects introduced by the use of different census methods.

In a local scale, Tubelis and Cavalcanti (2001) and Fieker (2012) found more bird species in more complex vegetations than in simpler ones, but they did evaluated only grasslands and savannas Cerrado vegetation types. These authors attributed the great diversity found in more complex areas to great opportunities to species colonization. Motta-Junior et al. (2008) did not statistically analyse the difference among number of species in savanna and grassland vegetations, but found more species in savanna vegetation than in grasslands, even using in savanna half of sampling effort used in grasslands. In turn, Valadão (2012) and Posso et al. (2013) did not found statistical differences in bird diversity among cerradão forest and cerrado savanna, but found greater bird richness in riverine forests. They concluded that only riverine forests may provide more resources to species than other Cerrado sensu lato physiognomies. Alternatively, Silva (2004); Rodrigues and Faria (2007); Piratelli and Blake (2006) found an opposite trend of lower bird species in forests than in savannas and fields. Silva (2004) sampled savanna patches surrounded by forests and observed some species not exclusively dependent of forest foraging in savannas. He pointed that savanna bird diversity could be enriched by the influence of forests in the nearby. Finally, Piratelli and Blake (2006) found more species in cerrado than in cerradão and argued that this pattern could be generated to the major disturbance level in cerradão forest 
than in savanna or even by the influence of the mist net method, that could undersampled species of mid and upper canopy in cerradão. This latter study was the only among these studies that mentioned the influence of census method in the bird diversity as one of the possible explanation for the unexpected pattern of decreasing diversity with increase of vegetation structure. Before him, Macedo (2002) suggested that greater diversity in savanna than in forest found by Fry (1970) could be due to point counts detection biases occurring more strongly in forests than in savannas, which is one of the effects found in our results.

Indeed, although many of the ecological mechanisms proposed can be in play, the above case studies also differ markedly in their census methods and sampling designs, which can affect the recorded number of species. Our study shows that the three most used methods can present biases in the number of species recorded per hour in each vegetation type. This effect of different method detectabilities can alter the total number of species recorded in a site, if the sampling effort will not sufficient to reach the assymptote of species accumulation curve (Gotelli and Colwell, 2001). The issue of detection heterogeneity is know since the half of last century (e.g. Burnham and Overton (1979)) and in the recent years several studies in temperate regions have proven its importance and proposed different methods to lead with this potential problem (Boulinier et al., 1998; MacKenzie et al., 2003; Mackenzie et al. 2002 Dorazio and Royle, 2005). However, this topic deserves more attention because there is no consensus about the real advantage of it, mainly in very diverse systems. For example, Banks-Leite et al. (2014) evaluated the conclusions of three case studies that measure occupancy rates and population size in mammals and birds in tropical region of Brazil. They found that the results did not change qualitatively if detectability was considered or not. These authors also argued that the effort necessary to estimate detectability in community surveys at large scales is hardly feasible. This controversy points to the need for a deeper exploration on the relative gain of using methods that consider differences in detection among species, locations and methods, especially in rich and unexplored regions, such as the tropics. Alternatively, our study seems to be different because the variable of interest (bird diversity) can be positively influenced by vegetation struc- 
ture while the vegetation structure itself may negatively influence the detectability of the species. Therefore, we think that studies designed to account for detection heterogeneity using multi-species occupancy models could help to clarify the importance of detectability in community ecology studies.

By our results, the effect of phytophysiognomy on observed bird diversity depends on the census method used, which prevents us to make general conclusions about bird diversity among phytophysiognomies if census method is not accounted for. According to da Silva (1995, 1997); da Silva and Bates (2002), $80 \%$ of bird species of Cerrado are dependent of forests in some degree, and the remaining $20 \%$ are almost exclusively dependent on open areas. Also, Blamires et al. (2008) found that the bird diversity in the Cerrado biome is strongly related to temperature and actual evapotranspiration. These climatic variables are proxies of vegetation production (Kissling et al., 2008), suggesting a correlation between plant biomass and bird species richness. As the complexity of vegetation in Cerrado is strongly linked to the increase of plant biomass from the grasslands to forests, these results suggests that number of species would be greater in forests than in savannas and grasslands. We observed that only the transect method showed a trend of positive relation of bird diversity and vegetation structure. Point counts predicted more species in grassland and savanna vegetations than transects, but was strongly affected by increased vegetation structure in forests, probably by the increase of structures surrounding the observer. Transect method allows sampling in larger areas and can be more efficient than point counts to register more sedentary and territorial species. The presence of these species can be more important specially in forested vegetations, where the home ranges of species can be smaller, by the higher density of food items in more complex vegetations (Schoener, 1968). Alternatively, bird species can be warned and could be not detected by the distraction and noise production while the observer moves on vegetation, which in point count method is less probable to happen, since the observer remains at the same place during censusing. These facts could explain why the number of predicted species per hour using point counts was greater in all phytophisiognomies than the predicted by transects, and also why the predicted bird richness decreased strongly in forests sampled 
with point counts. Moreover, we observed that the best model in our analysis predicted a similar number of species for all the three vegetation types by the mist net method, with a slightly decrease in estimated bird diversity with increasing vegetation structure. Mist nets capture more frequently birds that use understory and midstory habitats. By this, it is possible that the use of mist nets in open habitats will provide a better representation of the entire community, while in higher vegetation types, the proportion of habitat sampled will be smaller and captures will possibly reflect just the diversity where the nets are opened (Bonter et al., 2008). Then, by all these effects, we believe that detectability should also be considered to evaluate the efficiency of these different census methods.

Our conclusion is that a positive relationship between bird diversity and vegetation structure in the Cerrado is not so obvious as we initially expected because the estimates of diversity in phytophysiognomies varied widely depending on the census methods used. We believe that sampling designs that allowed the comparison of species richness considering the detection heterogeneity among environments and among census methods, are essential to better understand the relationship of bird diversity and vegetation structure in Cerrado. Based on these informations, we can build reliable conservation plans for this and other rich and threatened tropical biomes, avoiding misinterpretations of the results and mistaken conclusions as well (Gimenez et al. 2008).

\section{Acknowledgements}

We thank Camila T. Castanho, Sara R. Mortara and Renato A. F. Lima for the important suggestions on the initial version of the manuscript and also to Karlla V. C. Barbosa for the great help in compiling data and building the map of the sampled regions. We also thank Capes Federal Government Agency and Departamento de Ecologia of Universidade de São Paulo by the financial and institutional support. 
Capítulo 3

Bird diversity and vegetation structure relationship:

Effects of vegetation gradients on species richness and detectability in Cerrado savanna, Brazil 


\section{ABSTRACT}

Vertical vegetation structure and heterogeneity are among the most important variables in the determination of bird species diversity. Several studies had related different measures of vegetation structure with diversity and number of bird species around the world. Habitat Heterogeneity Hypothesis proposes that the more heterogeneity and structure of the vegetation, the greater the resource diversity and resource availability in the environment, allowing a greater coexistence of the species. We analysed this relationship using data on the bird species richness and vegetation structure in the Cerrado savanna biome, that is characterized by a heterogeneous mosaic of habitats that greatly vary in vegetation structure. Species richness was calculated using bayesian multi-species occupancy-detection models, which estimate the richness based on the probability of occurrence and detection of species. In turn, vegetation structure was measured by vegetation presence in 16 height intervals equally distributed between 0 and $4 \mathrm{~m}$. The vegetation data were summarized using principal component analysis, which resulted in two orthogonal axes that represented $72 \%$ of the variation of data. These two vegetation covariates were related to species occurrence and also to species detection, since vegetation can influence positively the occurrence and richness but could interfere negatively in the species detections. Other variables, such as the period of the year and of the day were also used as covariates of detection. Species richness in each site was estimated by this multi-species occupancydetection models and was related to vegetation covariates using a bayesian metanalysis model. We used a quadratic function to describe the relationship of estimated species richness with vegetation structure and we also fitted a quadratic GLM model to the observed species richness data, in order to compare the results of both models. Using data of the 38 most detected species, we noted that estimated and observed species richness provided qualitatively similar explanations about the relationship of bird species richness and vegetation structure gradients. Both models predicted higher species richness at the middle of vegetation height gradient and slightly higher species richness where vegetation presence below $2 \mathrm{~m}$ was high. However, estimated species richness showed less markedly trends than those of obtained from observed species richness, which pointed to greater in- 
fluence of imperfect detection at sites where vegetation is characterized by grasslands and more arboreal savannas, and also where vegetation below $2 \mathrm{~m}$ is scarcer. By these results, we concluded that diversity of most detected bird species weakly responded to vegetation gradients in our study area in Cerrado and the effects of vegetation on species detection can increase the intensity of the relationship among bird diversity and vegetation. Future studies focused on include information of the most rare species, as well as other focused on analyse species dynamics and composition in Cerrado vegetation gradients will generate valuable information to the ecology and conservation of bird species in this rich and threatened biome.

Keywords: avifauna, habitat heterogeneity, hot spots, multi-species models, detectability 


\subsection{INTRODUCTION}

Vertical vegetation structure and heterogeneity are among the most important drivers of bird species diversity (MacArthur and MacArthur, 1961; Wiens and Rotenberry, 1981; Cueto and de Casenave, 1999, Tews et al., 2004, Ferger et al., 2014). For instance, a positive effect of foliage height diversity on the diversity of bird communities was noted in the pioneering bird ecological studies of Robert H. MacArthur (MacArthur and MacArthur, 1961; MacArthur et al. 1962). This measurement of vegetation structure was taken by calculating the diversity of foliage density in horizontal layers at different heights above the ground, being the most structurally diverse the sites where foliage density varied the most among the layers. Since then, other studies had related the increase of bird species richness and diversity with the increase of vegetation height and vegetation strata Wiens and Rotenberry, 1981; Cueto and de Casenave, 1999; Jankowski et al., 2013; Azpiroz and Blake, 2016) and also with the increase of vegetation heterogeneity (i.e. diversity of plant forms or phytophysiognomies) at local (Poulsen, 2002, Díaz, 2006, Ferger et al., 2014) and landscape scales (Bohning-Gaese, 1997, Kissling et al., 2008). These studies reinforced the central role of vegetation structure and heterogeneity for the distribution of bird diversity in the world. This pattern can be explained by the "Habitat Heterogeneity Hypothesis" (Tews et al., 2004), or even "Vegetation Structure Hypothesis" as used by Kissling et al. (2008). These two are mechanistically based on the "Resource Specialization Hypothesis", which suggests that the increase of habitat heterogeneity (and/or structure) could affect positively the diversity and availability of potential resources in the environment (e.g. food, perches, shelter and nest sites), promoting specialists occurrence and also the coexistence of more species (Wilson, 1974, Hurlbert, 2004). Savanna biomes are amenable systems to test this hypothesis, since it covers around $20 \%$ of Earth's land surface (Field et al., 1998) and presents great vegetation heterogeneity at local and regional spatial scales. Vegetation types in savanna ranges from open grasslands to forests, often arranged in complex mosaics. This heterogeneity is maintained by some kinds of disturbances, such as grazing, browsing and fire occurrence (Doughty et al., 2016). Cerrado Brazilian savanna is the sec- 
ond largest and the second most threatened biome in Brazil. Cerrado vegetation can vary from grasslands, woodlands and forests (Figure 3.1), which results in a marked vegetation structure gradient and is the most evident environmental gradient in this biome. Previous studies had already found evidences of a positive relationship of Cerrado vegetation structure with species richness of mammals and birds (Redford and Fonseca, 1986, Johnson et al., 1999; Tubelis and Cavalcanti, 2001; Motta-Junior et al., 2008; Fieker, 2012). However, studies on the relationship between bird diversity and vegetation structure in Cerrado still are inconclusive, mainly by effects of vegetation structure on efficacy of bird sampling methods and possibly by detectability heterogeneity among species and along the vegetation gradient (Rodrigues and Prado in prep.). These facts can affect the conclusion of studies if vegetation also influence the detectability of species (Gu and Swihart, 2004) and none of these studies performed in Cerrado had considered imperfect detectability in their analyses.

Despite the ubiquity of a positive relationship among vegetation structure and heterogeneity with species diversity in the ecological literature, vegetation structure can also act as barriers for visual contact and for sound propagation, which could decrease bird detections (Bibby et al., 1992). In a field study proposed to analyse the effect of shrubbiness on occupancy, detection and richness of bird species in Alaska, McNew and Handel (2015) found that the detection of $90 \%$ of species sampled were negatively related to their shrubbiness index. This metric was calculated by the percent cover and height of the main two shrub types and also by a measure of visual obstruction, that was based on height and density of shrubs occurring in the sampled areas. Besides this, occupancy of most species and community species richness estimates showed positive relationship with shrubbiness when detectability effect was accounted for. They also found that raw observed species richness did not presented any relationship with shrubbiness, probably due to the harmful effect of vegetation on species detection. In a simulation based study, Gu and Swihart (2004) proposed to evaluate the influence of imperfect detection on species occurrence in a environmental gradient. They noted that the imperfect detection could generate biases in occupancy estimates, and these biases can be greater when detection was related with 
the habitat covariates. In this case, biases can also be more or less pronounced depending if detection and occupancy are positively or negatively related with habitat variables (MacKenzie et al., 2006). Other studies also pointed to a potential influence of vegetation structure, as well as other variables such as season, weather and noise, on species detectability (Stauffer et al., 2002, Zipkin et al., 2010), despite the effects of some of these variables have not yet been tested. Occupancy-detection models include an important theoretical refinement for many biological and ecological studies, that is the consideration of species detection and species occurrence as two different, but linked, processes. These models had been used from population to metacommunity studies and they had pointed to the importance of considering detectability heterogeneity to determine accurately occupancy and also species richness patterns (Zipkin et al., 2010; Ruiz-Gutiérrez and Zipkin, 2011 Mihaljevic and Johnson, 2015). These studies argues that detection heterogeneity should be included in studies to avoid misunderstanding of ecological patterns and processes and consequently to misleading conservation and management actions as well. However, these models presents a cost in relation to traditional methods due to the higher sampling effort needed to achieve accurate parameter estimates. Detection probabilities are calculated based on repeated surveys of the same site in a short period of time and very rare and cryptic species hardly will provide sufficient data to permit these estimates, even with unrealistic high sampling effort (Banks-Leite et al., 2014). Even though, these models that consider detection heterogeneity can be specially important to better inform policy makers in situations of species and ecosystems management and also in the development of ecological studies focused on determine species responses to environmental gradients, such as those found in the in Cerrado savanna and other heterogeneous vegetation mosaics.

Therefore, our study aimed to analyze the relationship between bird species richness and occupancy and vegetation structure in the Cerrado savanna vegetation mosaic. We proposed to do this considering also the potential effects of imperfect detection on species, different habitats and sampling occasions, which we believe will provide a more accurate view of the species-habitat relationship in the Cerrado biome. To do this, we used a multi-species occupancy model approach to investigate how species species richness and 
occupancy were related with habitat covariates. At the same time, we quantified the effects of these habitat covariates and other sampling covariates on detection of species during our surveys. We expect that bird species richness will increase with vegetation structure gradient in a Cerrado vegetation mosaic, as proposed by the "Habitat Heterogeneity Hypothesis". However, we also expect that vegetation can also negatively affect our perception of this relationship, through biases caused by imperfect detection.

\subsection{METHODS}

\section{Study area}

We collected data of species occupancy and detection in sites at the Grande Sertão Veredas National Park (PARNA-GSV), Central Brazil (Figure 3.1). The climate of the region can be defined as "Aw", by Köppen classification, or tropical with a marked dry season during winter (April-October period). The rainy season extends from November to March and almost all rainfall (1200 mm annual average) occurs in this period. The park has an area of 223,000 ha of well preserved Cerrado, however, north Minas Gerais and south Bahia, as well as other big Cerrado remnant areas, are being fastly occupied by monocultural plantations (Spera et al. 2016). The vegetation of the region is characterized by different Cerrado vegetation types, from grasslands to woodlands and forests. Some vegetation types are strictly associated with presence of water bodies, such as seasonal humid grasslands, riparian and gallery forests and also "Veredas" palm swamps. As we are interested in vegetation structure effect on bird communities, our study focused only in the Cerrado lato sensu gradient, that include grasslands, savannas and dry forests. These vegetation types occurs in more elevated areas and frequently in vegetation mosaics. The spatial distribution of these patches are determined mainly by gradients of soil depth and fertility, and also by fire occurrence (Ratter et al., 1997, IBAMA, 2003). We searched for homogeneous patches of vegetation of at least $400 \mathrm{~m}$ of radius, where we centrally located our sampling sites. However, some of patches were less wide but longer (e.g. some grasslands adjacent to Veredas swamps presented $50 \mathrm{~m}$ wide, but more than $1 \mathrm{~km}$ long), 
which we believe to be patches larger enough to house bird communities that are related to habitat features.

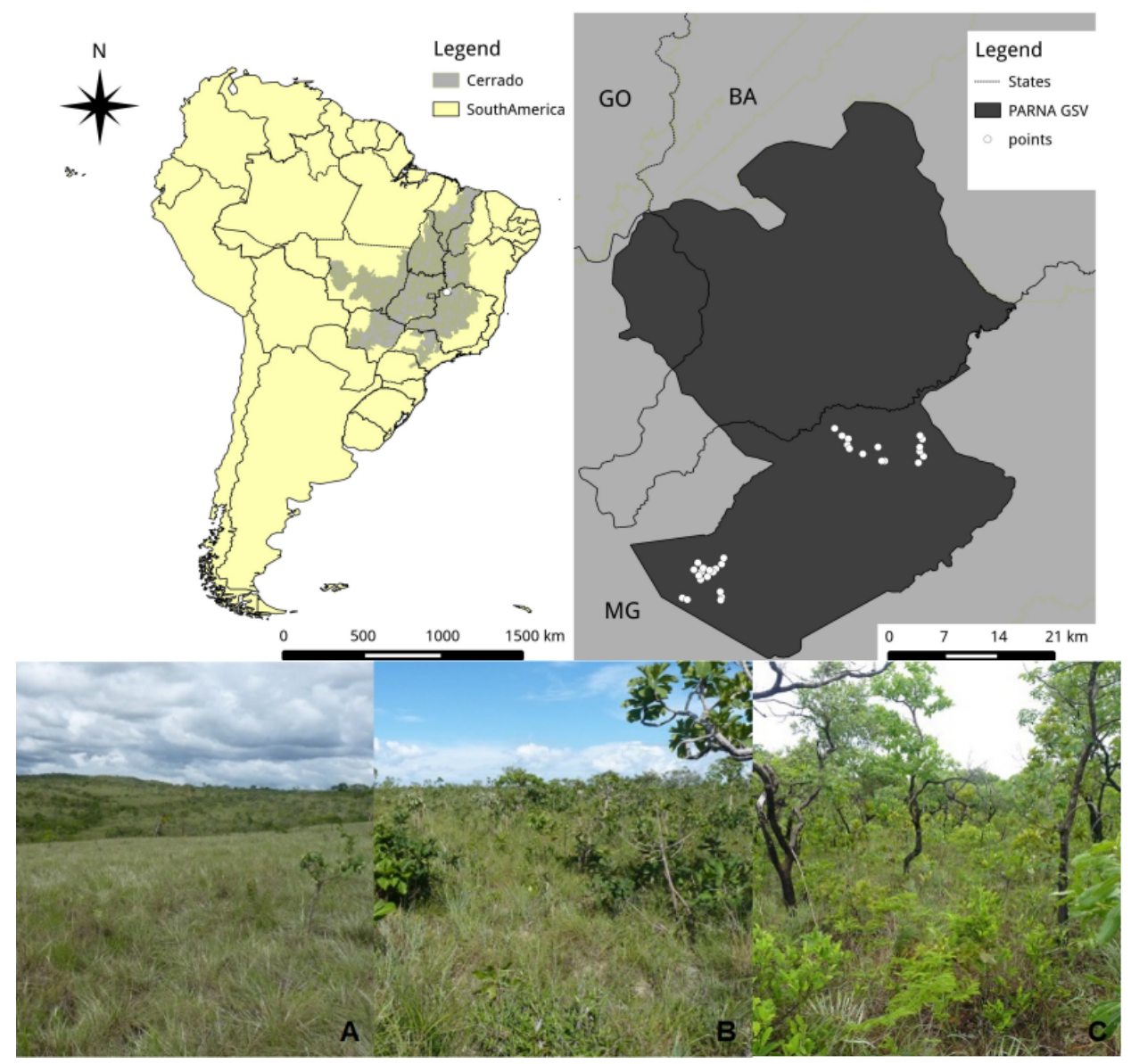

Figure 3.1: Cerrado vegetation distribution map in Brazil and detailed view of sampling points location inside Grande Sertão Veredas National Park area. Pictures at the bottom shows examples of sampled sites in the vegetation gradient. A: grasslands; B: open savanna; $\mathbf{C}$ : savanna

\section{Bird sampling}

We distributed 32 sampling sites (at least 400m distant from each other) in a gradient of Cerrado lato sensu vegetation structure, including patches of grasslands, open and more dense and arboreal types of savanna; Figure 3.1). We distributed our sites in two main areas of the park, which was done to represent a larger area and to reduce the travel time and distance to visit the sites. We avoided areas with history of human occupation or disturbance. These areas are concentrated around the houses of former residents of the park area and were identified by the report of park rangers. The fieldwork was carried out in two sampling seasons of 20 days each, during November-December 2014 and march 
2015. These sampling periods were planned to sample bird community during the rainy season, which is the main reproductive period of Cerrado birds and when species present greater activity. Bird samplings were done from sunrise to the next four hours, which is the period of highest activity of most Cerrado birds.

\section{Study design}

We set two transects of $200 \mathrm{~m}$ length in each of the 32 sites. The transects ran perpendicular of roads and were at least $50 \mathrm{~m}$ apart. Surveys in these transects were made using the transect method of bird census, which consists to register birds while the observer travels by a path with constant speed (Bibby et al. 1992). Each sample period lasted 20 minutes and were made by two doubles of observers (one observer and one field assistant), which allowed us to survey the two transects of each site simultaneously. During the sampling, the observer and the assistant walked in the transect with constant speed $(1 \mathrm{~km} / \mathrm{h})$ and recorded and identified all birds seen or heard inside a buffer of $100 \mathrm{~m}$ around the transect. After the first period of sample in each site, observer doubles alternated transects and both observers initiated another sample period at the same site. Then, we collapsed data of these four sampling periods (two samples of 20 minutes of each observer), which resulted in sampling occasions of 80 minutes. Also, half of the 32 sites were surveyed once and the other half two or three times during each sampling season. We assumed that each sampling season is closed to non random species migration, then, this temporal replicates in each season of sampling allowed us calculate detection probabilities of species (MacKenzie et al. 2006).

\section{Covariates of habitat and detection}

We measured the vegetation structure in each sampling site by using an adaptation of Wiens and Rotenberry (1981) method to characterize shrubsteppe vegetation in US. This measurement consisted of counting the presence of vegetation in 16 height intervals (approx. $22.5 \mathrm{~cm}$ each) in 20 vegetation sampling points in each transect. Each measure of vegetation structure had been taken every ten meters, alternating the two sides of each 
transect. To help in this task, we used a $4 \mathrm{~m}$ long bamboo rod with marks delimiting each height interval. We recorded the intervals where any live vegetation (grass, herbs, shrubs, trees) was in contact with the rod. We used a PCA analysis to summarize the count data of vegetation presence by height intervals. This analysis was made using "prcomp" function of stats $\mathrm{R}$ package and we scaled and centered at zero our variables to reduce skewness and standardize the variances (Venables and Ripley, 2002). We used the first two axes of PCA analysis (hereafter PC1 and PC2) as our vegetation structure covariates. The total percentage of variation presented by these two PCA axes was $72.1 \%$ (53.8 and $18.3 \%$ for PC1 and PC2, respectively). PC1 ordered the sampled sites by the increase of presence of vegetation by height (Figure 3.2). Grasslands sampling sites, which have predominance of vegetation presence in the first height interval presented PC1 values lesser than -2 , while open savanna sampling sites presented PC1 values from -2 to 1 and arboreal savanna sites presented PC1 values from 1 to 6 (Figure 3.2). On the other hand, PC2 axis presented negative values for points with greater presence of vegetation in the lower $1.5 \mathrm{~m}$ (from 1 to 7 height intervals, mainly open savanna sampling sites) and positive values for sampling sites that presented greater presence of vegetation in the first height interval and above $1.5 \mathrm{~m}$ height (grasslands and savanna sampling sites) (Figure 3.2).

In the same way we believe that vegetation structure could affect positively the bird species richness, we think that vegetation structure could affect negatively bird detection. Then, as we sampled sites disposed in a vegetation gradient, we thought we also need to include the two vegetation structure variables (PC1 and PC2) as covariates of detection. Additionally of these two covariates of detection, we also included the date of each sample (converted to count data, being first season receiving values from 1 to 20 and second season values from 21 to 38 ) and the mean temperature during the sample as covariates of detection. As our samples were taken during the rainy season (and after the incoming of migrant species in communities), we did not expect non-random changes in species occupancy between the two sampling periods. However, we decided to model detectability effects between sampling periods, to reduce detection heterogeneity among samples. In the same way, as temperature can present a negative effect on bird detections and it increases 


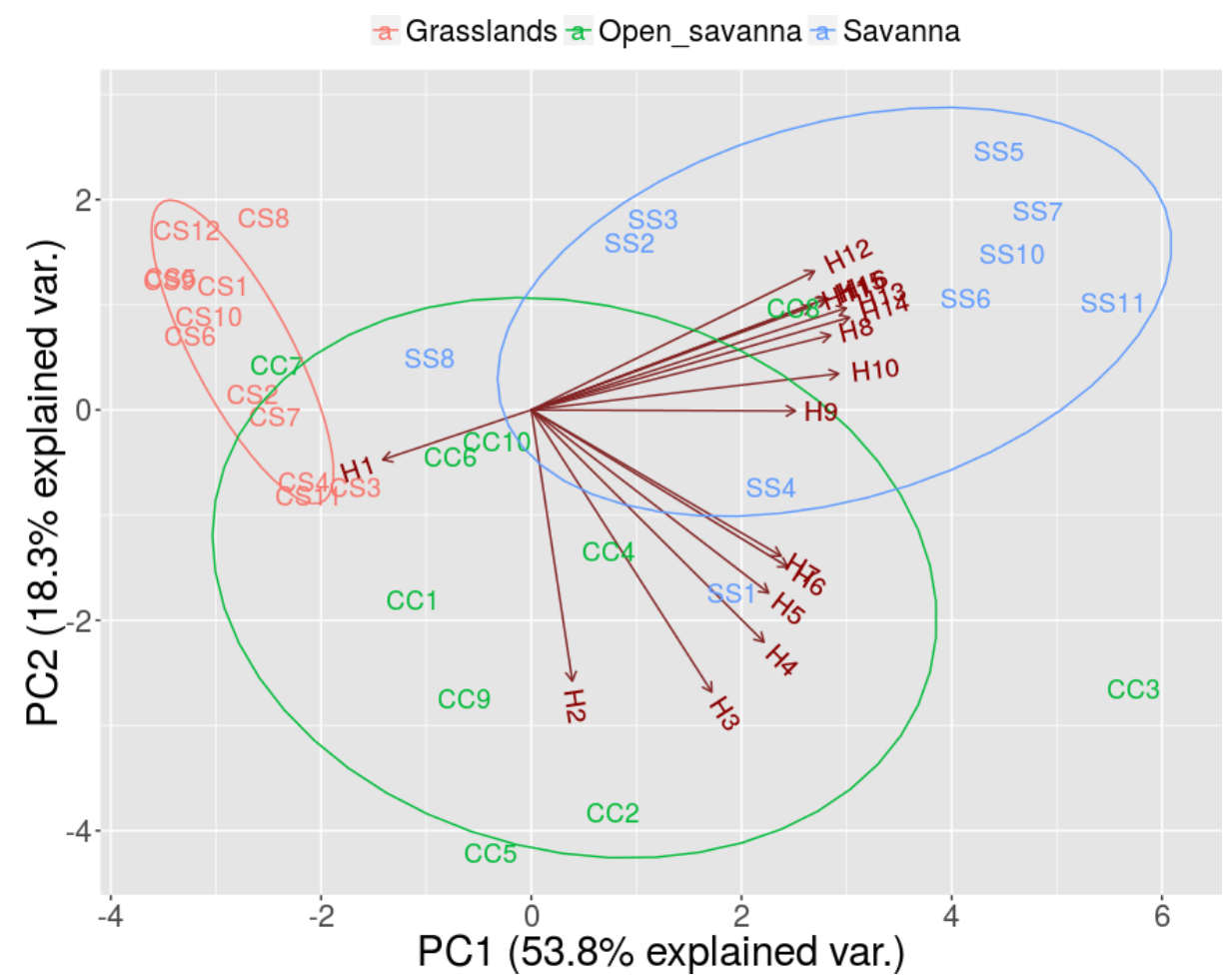

Figure 3.2: Ordination plot of Principal Component Analysis (PCA) for vegetation structure of sampled points.

fastly during the day specially in more open vegetation types of Cerrado, we also modelled the potential effects of mean temperature during the samples in bird detections. Both count dates and temperature variables were standardized to improve parameters convergence.

\section{Response variables}

As explained above, we sample all birds seen or heard inside a buffer of $100 \mathrm{~m}$ wide around the transects, excluding species observed flying over the transects and also species inside the buffer but using another vegetation type (e.g. species detected inside Veredas swamps was not considered in samples of adjacent grasslands). We just recorded the presence of each species per sampling occasion. Then, we estimated the number of species in each site using a multi-species occupancy models approach. The idea behind this approach is to calculate the occupancy of each species at each point, considering also the probability of detection of each species in each site and in each sampling occasion (see details below). After that, occupancy probability is translated in presences or absences of species given our occupancy-detection model and the number of species is estimated by summing the 
number of species that was estimated to occur in each site (Kéry and Royle, 2016). Alternatively, total number of species recorded during all sampling occasions was used as our naive estimation of species richness in each site. To access the occupancy patterns of species in the vegetation gradient, we analysed occupancy estimates for each species and for each site. This procedure allowed us to evaluate if some regions of the gradient are more densely occupied than others, which can give us an additional view of the use of vegetation gradient by bird species.

\section{Statistical models and analyses}

Despite the idea of detectability heterogeneity affecting the estimates of population size dates back the 1970's (Otis et al. 1978), the hierarchical model of occupancy used by us was recently developed by Mackenzie et al. (2002) and nowadays had gained much more attention. These occupancy models are considered hierarchical because they represent two different, but linked processes: the first is the underlying ecological pattern of occupancy, which we are more frequently interested to, and the second is the sampling process itself, which is directly affected by detection heterogeneities among species, sites, sampling periods and/or other variables as well. By expanding this first development, other models and protocols are being proposed to analyze and estimate occupancy and detection of multiple species simultaneously (Kéry and Royle, 2016), or even to estimate parameters for community and metacommunities (Sutherland et al., 2016). We used the two-step multi-species analysis, which is the most simplest protocol for estimate species richness and relate it with habitat variables (Kéry and Royle, 2016). In this approach, the first step consists of estimating species richness from species occupancy in each site, by using a occupancy-detection bayesian hierarchical model (BUGS code in Appendix B.1). We used Bernoulli distributions to model the occurrence and detection of species in each site and sampling occasion. Then, the occurrence of each species in each site can be represented by $z[i, k] \sim \operatorname{Bernoulli}(\psi[i, k])$, where $\mathrm{z}$ is a latent variable of the presence or absence of each species per site given our model and species-site $\psi, \mathrm{i}$ is the indexation for sites, $\mathrm{k}$ is the indexation for each species and $\psi$ is the probability of occurrence. The detection probability 
of each species, however, is calculated by each sampling occasion, and the detection of each species can be represent as $d[i, j, k] \sim \operatorname{Bernoulli}(z[i, k] p[i, j, k])$, where $\mathrm{d}$ is the detection or non detection of species during that survey (given the species is present in that site i.e. $z[i, k]=1), \mathrm{j}$ is the indexation for the sampling occasions and $\mathrm{p}$ is the probability of detection for each species per site and sampling occasion. These probabilities $(\psi$ and $\mathrm{p})$ were related with covariates by imposing that mean logit of these probabilities are linearly related with covariates. Then, these relationships are described by $\operatorname{logit}(\psi)=\beta_{0}+\beta_{1} x$ $\operatorname{logit}(p)=\alpha_{0}+\alpha_{1} x$, where $\beta_{0}$ and $\beta_{1}$ are the intercept and slope of the linear relationship of occupancy and the covariate, $\alpha_{0}$ and $\alpha_{1}$ are the intercept and slope of the linear relationship of detection and the covariate and $\mathrm{x}$ is the covariate of occupancy/detection itself. The number of species per site was calculated by the sum of species occurring in that site given our model (i.e. $\left.\sum z[i],\right)$ and the mean number of species and uncertainty around these estimates per site were calculated by the estimated species richness obtained in each model iteration.

The second step consists of relate mean number of species and uncertainty around the estimates with habitat variables, using a bayesian metanalysis model (BUGS code in Appendix B.1. In this model, the species richness of each site was modelled by using a Normal probability distribution function, with mean number of species varying quadratically with habitat covariates, namely, $N[i] \sim a+b x+c x^{2}+e[i]$, where $\mathrm{i}$ is the index for each site, $\mathrm{a}, \mathrm{b}$ and $\mathrm{x}$ are the intercept, slope and covariate of interest, respectively, and e[i] is the uncertainty associated to the previous estimate of species richness. We ran the occupancydetection and metanalysis models using jags software and rjags $\mathrm{R}$ package, being the first used to implement MCMC algorithm for estimate parameters and the latter was used to allow connection of R software with jags. For the occupancy-detection hierarchical model, we estimated the parameters using three MCMC chains and 30000 iterations. The 5000 initial values were discarded (burn-in) and one within 25 estimates (thinning rate) was stored as sample of parameters posterior distributions. In the case of metanalysis models, we also used three MCMC chains but 12000 iterations each and 2000 burn-in iterations and also $1 / 10$ of thinning rate. In all models trails, we used uninformative priors for all 
parameters $(\psi$ and $p$ Uniform $(0,1)$ and other model coefficients and species richness $\mathrm{N}$ Normal (mean $=0$, sd $=0.001)$. we used 0.4 as initial values of $\psi$ and p probabilities for all species and initial values of other parameters were sampled from random Normal distributions ( norm function on $\mathrm{R}$, with mean $=0, \mathrm{sd}=0.001$ ).

\section{Model inference and evaluation}

We constructed two sets of models, one where occupancy, detection and species richness were related to PC1 and other where these quantities are related to PC2. Both sets of models include dates and mean temperature as covariates of detection. We opted to make inferences only on these models, because multiple comparison of multi-species hierarchical models (using some model selection and comparison criterion, such as DIC) can become inconclusive due to possible different species responses to environmental gradients (CarrilloRubio et al. 2014). In our case, this separation of models with different habitat covariates also prevent for non convergence during model parameters estimations, since with our data with were not able to estimate both covariates effects in the same model. Therefore, our models of occupancy, detection and species richness can be described as

$$
\begin{gathered}
z[i, k] \sim \operatorname{Bernoulli}(p s i[i, k]), \operatorname{logit}(\mathrm{psi})=a+b P C \\
d[i, j, k] \sim \operatorname{Bernoulli}(z[i, k] p[i, j, k]), \operatorname{logit}(\mathrm{p})=a+b P C+c J D+d M T \\
N[i] \sim \operatorname{Normal}(N[i], \operatorname{tau}[i]), N[i]=a+b P C+c P C^{2}+e[i]
\end{gathered}
$$

, where $P C$ stands for PC1 or PC2, in each model and JD and MT are dates and mean temperature covariates, respectively. All parameter estimates were checked for convergence by calculating the R-hat convergence metric (R-hat $<1.1$ means convergence of chains parameter estimates) and by visual inspection of chains convergence using the function "traceplot" of coda R package. Model fit assessments were made using bayesian p-value and posterior predictive checks (Gelman, 2003), which were calculated by using chi square statistic as discrepancy measure and implemented by the "ppcheck" function of jagsUI $\mathrm{R}$ 
package (Kellner, 2016) (Figure B.1, Appendix B.2)

\subsection{RESULTS}

We recorded 140 bird species from 14 orders and 36 different families (Table B.1. Appendix B.3). However, model parameters of rare species (less than 20 records) presented greater chances of non convergence in MCMC chains, which seemed to bias our view of species richness-vegetation structure relationship (Figure B.2, Appendix B.4, see also Discussion). Then, we repeated our analyses using just the 38 most detected species (those with more than 20 records) and we presented these results below. The mean estimated number of species per site after correcting for imperfect detection was 26.47 (sd $=2.96$ ) if we use PC1 as a covariate in the model and $25.61(\mathrm{sd}=3.63)$ for $\mathrm{PC} 2$, while the mean number of observed species was $18.96(\mathrm{sd}=6.93)$, which is lower that estimated species richness and presented standard deviation almost two times higher than we observed for estimated species richness. The inspection of both GLM and Bayesian multi-species models coefficients did not show relevant differences among them (Table 3.1). Also, both models presented the same relationship for PC1 and PC2 covariates, but credible intervals of Bayesian models were slightly narrow than confidence intervals of GLM model coefficients (Table 3.1).

The relationships of estimated species richness with PC1 habitat covariates showed that estimated species richness are slightly greater at lower and intermediate values of PC1, while observed species richness was higher at intermediate values of PC1 (Figure 3.3). In turn, the relationship of estimated species richness with $\mathrm{PC} 2$ vegetation structure covariate was weak but negative, while the observed species richness was negatively related with $\mathrm{PC} 2$ vegetation covariate (Figure 3.3).

The analysis of species occupancy showed that the mean occupancy in the model with PC1 as covariate was 0.68 and varied from 0.001 to 0.998 and was 0.66 , but varied between 0.0003 and 0.999 in the model with PC2 as covariate. Species occupancy values seemed to be higher at intermediate and high positive PC1 values, which represented the sites with 
Table 3.1 - Comparison between Bayesian multi-species (estimated species richness considering species occupancy and detection) and GLM (naive observed species richness) models coefficients. We also show the Bayesian Credible Intervals of $2.5 \%$ and $97.5 \%$ of Bayesian model coefficients and Confidence Intervals of $2.5 \%$ and $97.5 \%$ for GLM coefficients estimates. $a, b$ and $c$ model coefficients are the intercept, linear and quadratic effects of the covariate on response variable, respectively. The asterisks highlight the coefficients where BCI and CI intervals did not include 0.

\begin{tabular}{lccccc}
\hline Model & Covariate & Coefficient & Value & $\mathrm{IC}(2.5 \%)$ & $\mathrm{IC}(97.5 \%)$ \\
\hline Bayesian & PC1 & $a$ & 28.37 & 26.69 & 29.97 \\
& & $b$ & 0.42 & -0.05 & 0.88 \\
\multirow{3}{*}{ GLM } & \multirow{2}{*}{ PC1 } & $c$ & -0.18 & -0.34 & $-0.02^{*}$ \\
& & $a$ & 22.70 & 19.31 & 26.09 \\
& & $b$ & 0.67 & -0.25 & 1.61 \\
Bayesian & PC2 & $a$ & -0.44 & -0.75 & $-0.13^{*}$ \\
& & $b$ & 26.9 & 25.45 & 29.97 \\
\multirow{4}{*}{ GLM } & \multirow{2}{*}{ PC2 } & $c$ & -1.80 & -2.61 & $-1.03^{*}$ \\
& & $a$ & 19.01 & -0.67 & 0.01 \\
& & $b$ & -2.08 & -3.67 & $-0.48^{*}$ \\
& & $c$ & -0.01 & -0.69 & 0.66 \\
\hline
\end{tabular}

Psi PC1,p PC1+Dates+Temp

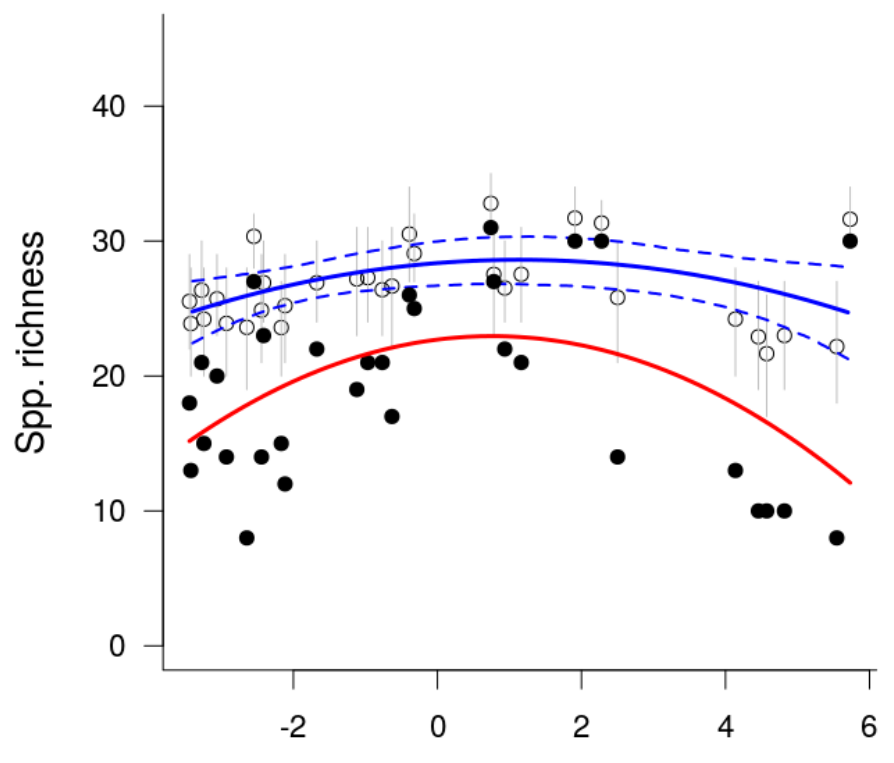

PC1 Veg. Index
Psi PC2,p PC2+Dates+Temp

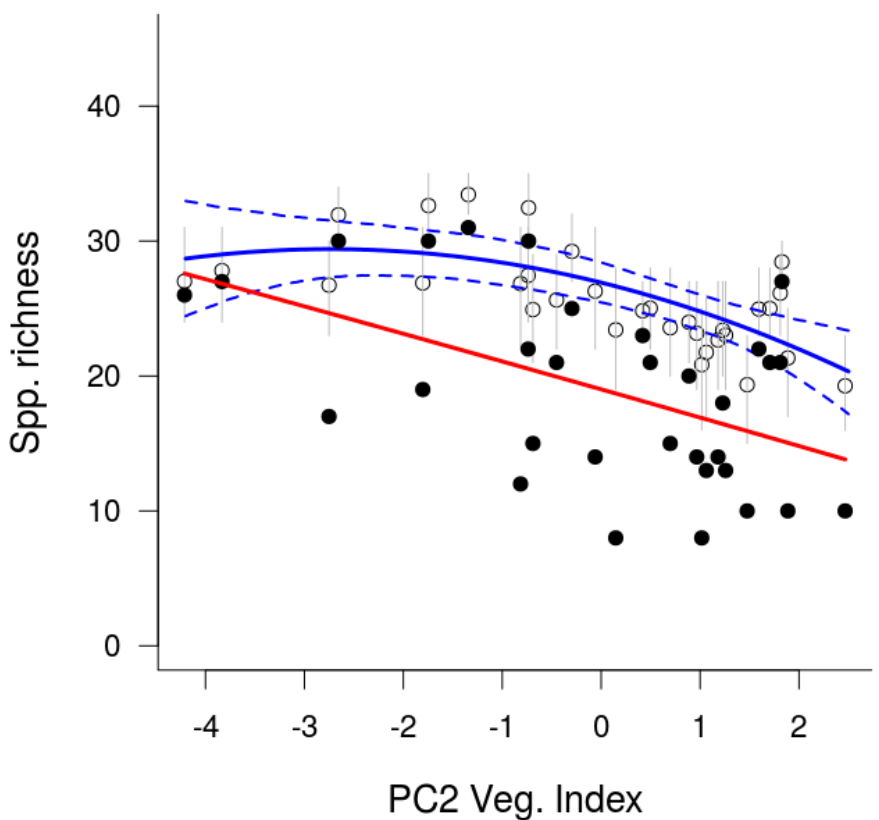

Figure 3.3: Relationship of estimated and observed (naive) species richness with vegetation structure covariates. White points and gray lines are the estimated species richness and $95 \%$ credibility intervals around the estimates. Solid blue lines are the species richness-vegetation structure model predictions and dashed blue lines are the $95 \%$ lower and upper credibility intervals. Solid black circles are the observed (naive) species richness for each site and solid red line is the prediction of a quadratic glm Normal-error model fitted to naive data. 
greater vegetation presence at intermediate and high height intervals, respectively (Figure 3.4). The sites that presented lower PC1 values and represented grasslands sites presented lower occupancy values for the majority of species (Figure 3.4). For the PC2 covariate, species occupancy was higher for lower values of this covariate and the majority of species also presented higher occupancy values near the middle of the gradient (between -1 and 0 PC2 values) (Figure 3.4. Negative values of PC2 covariate represented the sites with greater presence of vegetation below $2 \mathrm{~m}$ and intermediate and positive values of PC2 represented the sites with less vegetation presence in intermediate height intervals.
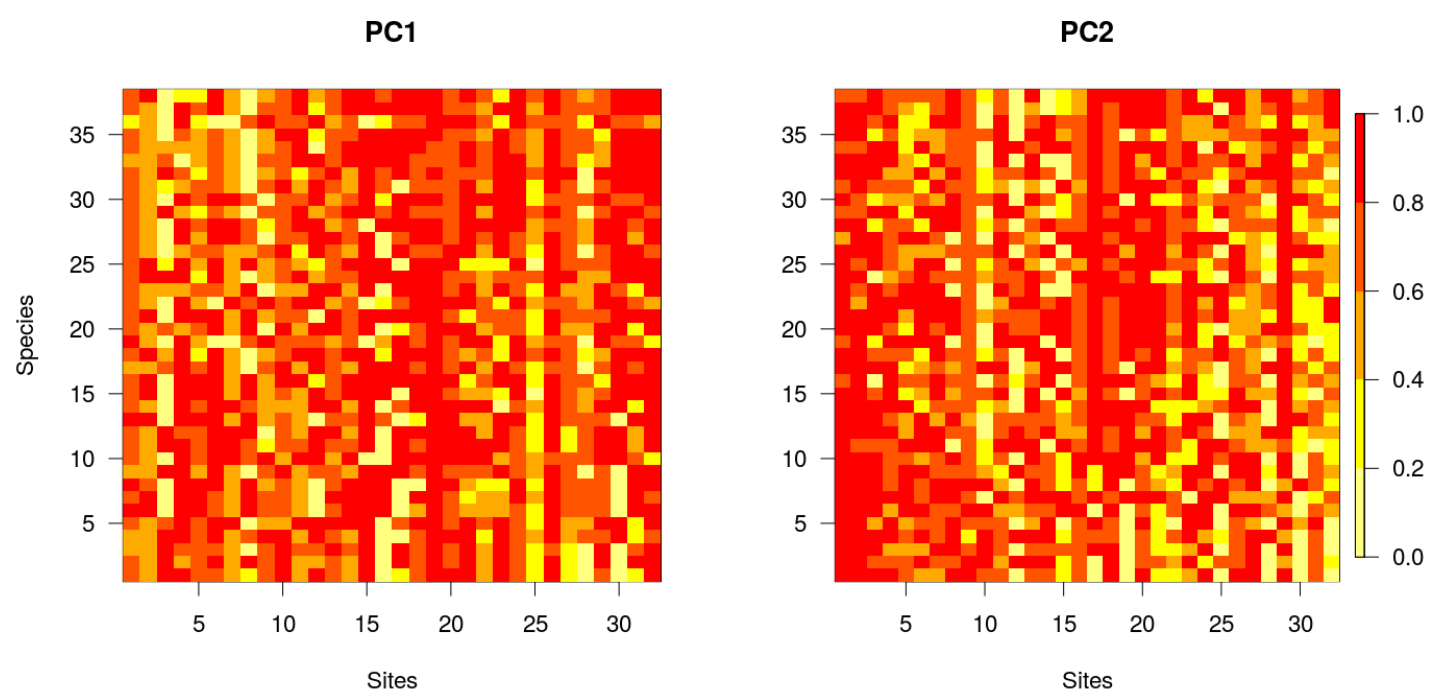

Figure 3.4: Occupancy patterns of species for the two vegetation gradient covariates. Cells colors are "warmer" where species presented higher occupancy values at each site. Species were ordered in rows by the mean of PC1 (or PC2) score divided by species occupancy at that site. In turn, the columns were ordered by increasing values of each habitat covariate.

Additionally, mean detection probabilities in the PC1 model covariate was 0.32 and varied from 0.007 to 0.90 , while in the $\mathrm{PC} 2$ model covariate mean detection was 0.33 and varied from 0.003 to 0.95 . Inspection of model's detection coefficients showed that the effect of PC1 habitat covariate on detectability depended on the species, being approximately half of species responding negatively and the other half positively related to this PC1 covariate. (Figure 3.5). PC2 habitat covariate also presented a negative relationship with detection for almost half of species, while the other half of species presented their detection positively related with PC2 habitat covariate (Figure 3.5). The other covariates of detection, dates count and mean temperature during the samples, also presented positive 
and negative effects on detectability of some species for both set of models (Figures 3.5). These parameter estimates showed that the effects of these variables on detection seemed to be quite variable among species.
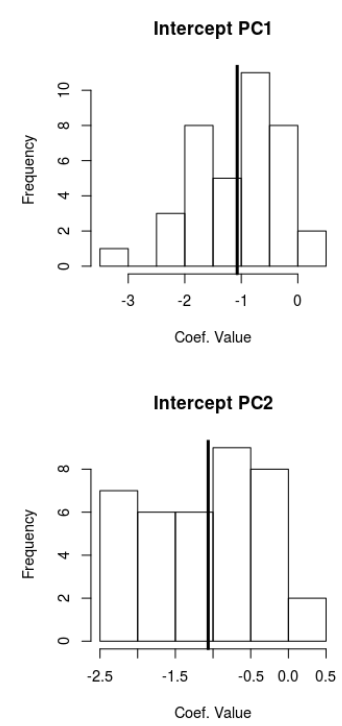

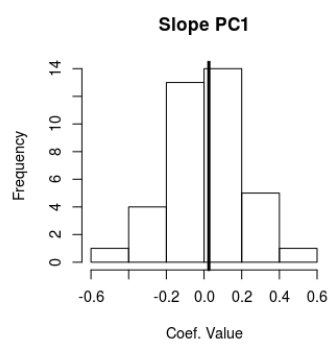

Slope PC2

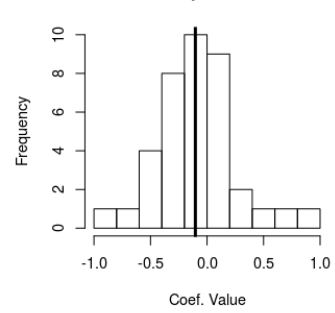

Slope Dates PC1

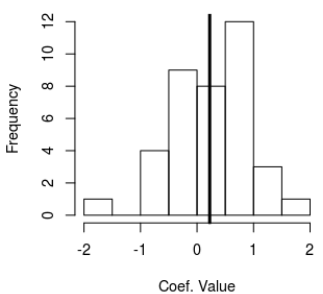

Dates PC2

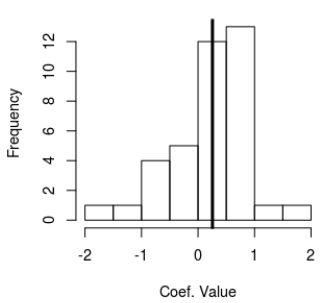

Slope Temp PC1

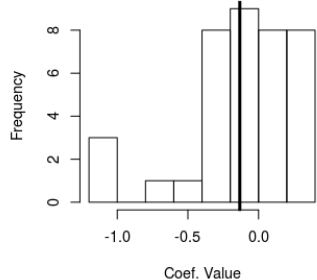

Slope Temp PC2

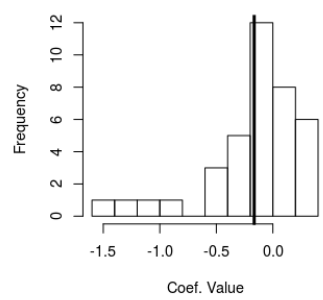

Figure 3.5: Histograms of detectability parameter values for each model. Top graphs are parameter values for that model where detectability and occurrence were related to $\mathrm{PC} 1$ covariate. Bottom graphs are the same parameters but for the model that include the effects of PC2 covariate on detectability and occurrence. From left to right: values of intercept coefficient, slope values for detection and habitat covariate relationship, slope values for detection and count dates sample covariate relationship and finally, slope values for detection and mean temperature sample covariate relationship. Black vertical lines represent the mean value of the coefficients for all the 38 species analysed.

\subsection{DISCUSSION}

Our work is the first study on the relationship of bird species richness and vegetation structure in Cerrado savanna that consider potential effects of vegetation on detectability. The models that considered vegetation effects on species detectability pointed to slightly greater number of species at sites with vegetation at the intermediate height values and at sites with more presence of vegetation below $2 \mathrm{~m}$. These relationships of species richness and vegetation gradients were also found when we considered the number of observed species (naive estimate of species richness) as our diversity measure, but in this case the relationships seemed to be more pronounced than those presented for estimated species richness. These results were contrary to our initial expectations, since most supported hypothesis in the literature proposes monotonic increase of species richness with increase 
of vertical vegetation structure, which in our study was represented by the PC1 covariate. On the other hand, the positive relationship of species richness with PC2 covariate showed that vegetation presence below $2 \mathrm{~m}$ indicated that species can be responding to the shrub component of vegetation, which are more abundant in open savanna sites and which are those sites with lower values of PC2 covariate. Since occupancy values we used to calculate species richness in our approach, species occupancy also was slightly higher at the middle of the $\mathrm{PC} 1$ vegetation gradient. In turn, $\mathrm{PC} 2$ vegetation gradient presented higher occupancy values at the lower limit and also at the middle of this vegetation gradient. Detectability effects varied greatly among species and we did not observe a general pattern of species detection responses to the covariates. However, the effects of imperfect detection during all samples was highlighted by the higher mean and lower variance of estimated species richness in relation to observed species richness and also by the less pronounced relationships of species richness and vegetation gradients when we consider detectability heterogeneity in species richness estimates. Then, if we use the observed species richness we could underestimate the presence of species and overestimate the importance of vegetation gradient to them, even we considering just the most detected species that are supposed to be less affected by problems related to imperfect detection.

The faster decrease of observed in relation to estimated species richness at both ends of vegetation height gradient and also in the areas with less presence of vegetation below $2 \mathrm{~m}$ suggests that detection can be influenced by vegetation characteristics. Canopy species can be less detected by the observer if they uses the upper part of the canopy, which is farther from the observer and darker, depending on the height and density of this vegetation layer. In a similar way, grass density is greater and the presence of perches is lower in pure grasslands than in open and arboreal savannas physiognomies. This habitat characteristics lead species that uses grasslands to forage on the ground and inside grass thickets, which could contribute to lower detection rates of species by the observer in the lower end of the vegetation height gradient. Consequently, species would be more detected in that sites where vegetation presented more shrubs and other vegetation forms in heights near to the observer's height of view. Macedo (2002) had already pointed that bird species probably 
presented lower detection probabilities in forests than in savannas, which could explain the greater species richness in the latter in relation to the former physiognomy, that was the result found by Fry (1970). On the other hand, McNew and Handel (2015) found that the shrubbiness of vegetation (a measure of visual obstruction of vegetation at a height of $0.5 \mathrm{~m}$ and the percentage and height of the two main types of shrubs in their study area) affected negatively the detection of $90 \%$ of the bird species in an Alaskan tundra. They also found that ignoring this negative effect of vegetation on detectability could alter the view of bird species richness-vegetation relationship. Then, the results of these two latter studies supports our findings that vegetation height and also density could affect bird species records and possibly may affect the conclusions of ecological studies as well.

In our study, the weaker relationship for estimated species richness in relation to observed species may signalize that the species does not have preferences for certain parts of the vegetation gradients in this Cerrado area. This result can be expected if we remember that in our analyses we restricted the species pool to the most detected species, that were also the most common bird species and probably those with less environmental requirements. However, Zipkin et al. (2010) used other approach to calculate species richness and they found that relationship of understorey foliage and tree basal area with bird diversity became more evident when they calculated bird community richness using occupancydetection approach rather than using only the observed species richness. McNew and Handel (2015) also found that the use of multi-species models revealed a positive relationship of bird species richness and vegetation structure, while the naive species richness did not show any relationship with their vegetation structure measurement. The approach used in these studies include all species recorded and the estimates of rare species parameter is feasible by assigning a common distribution for species parameters. Then, species are considered as random effects into the model and abundant species provide information about the distribution of parameters and consequently, for the parameters of rare and cryptic species as well. We opted by the two-step approach for two main reasons: the first is that we can calculate and incorporate uncertainty of species richness estimation in our metanalysis model, which we believe to be important to consider to a better interpretation 
of the relationship between psecies richness and the vegetation gradient; the second is that this model was tested via simulations by McNew and Handel (2015) and it presented some biases in represent the true relationship of species richness and an environmental gradient. These biases arised by the dependence of all species to a common distribution, which could force the species responses in the same direction. This assumption seems to be unreal in our situation, since some species presented opposite relationships to the same gradient. Thus, besides our approach is more conservative, our results provide a more accurate and informative view of the bird community diversity and vegetation structure relationship than other studies that focused their inferences in models fitted to individual species or those that uses naive data without considering detectability heterogeneity among samples.

We also model the relationship of total number of species, irrespective to the quantity of data, with our vegetation structure metrics and the results of these relationships are quite different to those observed for the naive data (Figures B.2 and B.3, Appendix B.4). In this case, species richness are greater in the both ends of the two vegetation gradients, while naive species richness presented the same observed pattern (but weaker) than those observed for the smaller data set. Besides the different patterns assigned by the two diversity metrics, the differences between values of estimated and observed species richness greatly increased, which pointed to bigger loss of using observed rather estimated richness values. According to Banks-Leite et al. (2014), one of the disadvantages of using species with insufficient data is that occupancy-detection model tends to attribute occupancy values close to 1 , but uncertainty around this parameter and in detection probability will be huge. This fact would increase the number of species occurring in sites where many rare species occurs, which will change dramatically the shape of species richness-vegetation relationship. Besides the risk of inflate species richness by the inclusion of rare species, the uncertainty around estimates of species richness remained quite low in relation to the observed species richness. Overall, we think that the treatment for rare species in these models need to be improved to a better representation of species-rich communities. As the increase of the number of records for these species in the field is not easy, other possibility provided by bayesian models is the inclusion of additional information on prior 
parameter distributions. This information can be gathered through expert interviews, that would assign probabilities to the occurrence of species which would allow us to build more realistic distributions for the occurrence probabilities of species. If the rarity status of species could be manipulated by imposing these different prior parameter distribution, may be the occurrence of rare species would not appear so widespread and the species richness in the community should not be overestimated. This solution was not tested already for the occupancy-detection models, since all studies to date provided non informative priors to the species occupancy and detection parameters. Nonetheless, if more knowledge about the system are included by using informative priors in our analysis, parameter estimates tend to be more precise (Kinas and Andrade, 2010).

The relationships of estimated species richness and vegetation structure gradients pointed to a slightly greater importance of intermediate height vegetation presence and also of vegetation presence below $2 \mathrm{~m}$. Other studies performed to analyse the relationship of vegetation structure and heterogeneity with bird diversity in Cerrado are not totally conclusive, mainly by some particularities of each one and also by lack of statistical treatment of these data. For instance, Fieker $(2012)$ found a positive correlation among bird diversity (calculated by Shannon Diversity Index) and total species richness with habitat complexity, measured using Shannon diversity index using 18 classes of vegetation and other structures and soil features in 50 plots of $2 \times 2 \mathrm{~m}$ in each sample site(e.g. percentage of grasses, four height classes of shrubs and trees, epyphites, percentage of area occupied by termites nests, soil burrows, bare and soaked soil). However, she also included flooded areas in her census (some that also presented greater habitat complexity) and her work was not totally clear about why correlation analysis was used instead of regression, that would be a more adequate analysis to stablish cause-effects relationships. Additionally, other two studies found a increase of bird diversity from grasslands to savannas, but they did not statistically test their results and did not standardized sampling effort among different habitats (Tubelis and Cavalcanti, 2001; Motta-Junior et al., 2008). Other studies did not found a increase of bird species from savannas to forests (Valadão, 2012; Posso et al., 2013) and others found that savannas presented greater species richness than forests and grasslands, but 
they also did not provide statistical treatment to their data Silva, 2004, Rodrigues and Faria, 2007; Piratelli and Blake, 2006), which can weaken the inference and generalization power of these data. In a recent compilation and secondary analysis of data published about species richness-vegetation structure gradient in Cerrado, Rodrigues and Prado in prep. also were not able to conclude about this relationship mainly by greater variability in the bird estimates due to the different sampling methods used in each study, which we know to be severely influenced by habitat characteristics variation inside the vegetation gradient.

Our study used a multi-species bayesian approach that explicitly lead with detectability heterogeneity among species, sample sites and occasions, at the same time we estimate occupancy probabilities and species richness relationships with habitat covariates. These analyses showed that the most detected species presented higher occurrences at the middle of the vegetation height gradient and also where vegetation is characterized by great vegetation presence below $2 \mathrm{~m}$. These species occurrence patterns resulted in slightly higher species richness at sites where vegetation is not exclusively formed by grasses or trees, but specially where small trees and shrubs (that represent the intermediate vegetation strata) are more abundant. Cerrado vegetation is majorly represented by savannas and its intermediate forms, while both grasslands and forests represent only $25 \%$ of total Cerrado area. Among species more often sampled by us, we noted that majority of them or are considered quasi endemic Cerrado species (e.g. Saltatriculla atricollis, Heliactin bilophus, Cyanocorax critatelus, Suiriri affinis, Schistochlamys ruficapillus, Thmanophilus torquatus, Neothraupis fasciata, Melanopareia torquata, Cypsnagra hirundinacea, Euscarthmus rufomarginatus or they are typical of more open vegetation types (Zonotrichia capensis, Elaenia chriquensis, Eupsitulla aurea, Sporophila plumbea, Ammodramus humeralis, Mimus saturninus, Eupetomena macroura, Synallaxis albescens, Elaenia cristata, Emberizoides herbicola, Gnorimopsar chopi, Tachornis squamatta, Rynchotus rufescens, Cariama cristata, Xolmis cinereus, Chlorostilbon lucidus, Phacellodomus rufifrons, Myiophobus fasciatus. In general, Cerrado bird species are less dependent of forests than other species from Atlantic and Amazonian rain forests, for example (Stotz et al. 1996). However, 
da Silva (1995) argued that near to $75 \%$ of species found in Cerrado are dependent of forest in some degree, but his analysis include common species in perypheral areas of Cerrado and ca have their origin in Amazonian and Atlantic Forests domains. We did not sample strictly Cerrado forested habitats during our study (e.g. Cerradão dry forests and riverine forests), but our samples included typical Cerrado species that are locally abundant in other Cerrado savanna remnants and natural areas. Then, our results can be viewed as the main response of most common Cerrado avifauna to vegetation, that seems to be positively affected by intermediate types of vegetation and also to shrub component of vegetation. Nevertheless, Cerrado also presents important areas of endemism that may be associated with the generation of both forest and grassland species and today these species inhabits enclaves of these types of vegetation scattered throughout the biome da Silva and Bates, 2002). Therefore, to achieve a better understand about the structure and distribution of the entire Cerrado bird diversity, it is imperative to consider how changes in community composition happens and whether there is a dynamic process of species occupancy-extinction along these vegetation gradients. Some studies had already analysed the composition of bird community and found that grassland formed separate clusters of species from those of savanna communities (Tubelis and Cavalcanti, 2001; Fieker, 2012) and other evidences pointed to the use of forests by Cerrado bird species (Tubelis et al. 2004) and also to the use of savanna by forest species (Silva, 2004). Novel studies in these fields are needed to expand our knowledge and incorporation of the occupancy-detection framework in those can yield more reliable data, and hence better implementation and greater effectiveness of conservation and management plans.

In relation of Cerrado birds conservation, our study have important implications. We found a weak relationship of bird species richness and occupancy with intermediate height vegetation and also with the presence of vegetation below $2 \mathrm{~m}$ height. This response of Cerrado bird species to vegetation gradient can point to the importance of shrub component of vegetation, that is more abundant in open areas of Cerrado. However, the lower magnitude of response shows that probably the entire gradient can be used by most bird species and grasslands could harbour as many species more forested habitats. Even though, 
some endemic and rare species are restricted to grasslands or forests da Silva and Bates, 2002 ) and the investigation of occupancy patterns of these species should be prioritized to measure beta diversity among the different physiognomies. Then, future studies in this topic that also consider the detection heterogeneity among habitats will greatly contribute to the regional maintenance of species diversity in this rich and complex biome.

\section{Acknowledgements}

We would like to acknowledge all field assistants, specially Gregório R. Menezes, Antonio C. da Silva, Karlla V. C. Barbosa, Thiago V. Costa, Hugo S. Pereira and Mário Sacramento, for the help during the fieldwork. Also, we would to thanks Gregório R.Menezes, Leonardo L. Wedekin, Marcelo Awade and members of LET laboratory by fruitful intellectual discussions during the elaboration of the study and of the manuscript. Finally, to the CAPES institutional scholarship program and FAPESP governamental agency, by the financial support of 2013/19250-7 research project. 
Capítulo 4

\section{Conclusões}

Nesta tese, a análise da "Hipótese de Heterogeneidade de Habitats" se deu a partir de duas abordagens distintas, que contrastaram principalmente na metodologia e delineamento da coleta dos dados e, consequentemente nas análises estatísticas utilizadas e nos resultados obtidos. No primeiro capítulo, realizamos uma busca extensiva de trabalhos publicados a fim de obter dados de riqueza de espécies em comunidades de aves de diferentes formações vegetais de ocorrência no bioma Cerrado. Estes dados foram levantados na literatura científica nacional e internacional, incluindo períodicos, teses e dissertações produzidas em diversas regiões do Brasil, além de relatórios científicos que visavam o conhecimento e investigação da diversidade em áreas de interesse público, como parques nacionais e estaduais. Todos os relatórios científicos e planos de manejo, assim como a grande parte dos estudos compilados por nós não apresentaram informações suficientes sobre o delineamento amostral e também sobre os metodologia desenvolvida durante o trabalho, o que reduziu ainda mais a quantidade de dados que poderiam ser analisados e replicados em trabalhos posteriores. Ainda assim, mostramos que a riqueza observada de espécies de aves em comunidades de Cerrado é determinada por uma interação entre a fisionomia vegetal amostrada e o método amostral utilizado. Isto significa que o número de espécies registradas em cada fisionomia vegetal depende do método amostral escolhido, sendo que cada um dos métodos mostrou uma relação diferente da riqueza de espécies com a estrutura da vegetação. Além disso, a variação estimada para os efeitos aleatórios mostrou que a variação nos valores dos efeitos fixos foi duas vezes maior devido à características dos estudos do que devido à variação nas localidades amostradas. Estes resultados reforçaram 
a influência de diferentes métodos de amostragem na quantificação da diversidade de aves e também a grande variação entre os estudos devido a fatores metodológicos, o que nos impossibilitou de determinar a relação da riqueza de aves com a estrutura da vegetação no Cerrado. Assim, além de um maior planejamento do delineamento amostral e uma maior clareza na definição e elaboração dos estudos, nós sugerimos que deveriam ser usados delineamentos e métodos mais robustos para lidar com efeitos da possível heterogeneidade de detecção entre amostras, entre espécies e também entre métodos amostrais. Estes métodos vêm sendo desenvolvidos com grande rapidez nas últimas décadas e apresentam um avanço teórico e aplicado muito grande, visto que a detecção imperfeita das espécies animais, e mesmo vegetais, está longe de ser uma exceção em estudos biológicos e ecológicos.

No segundo capítulo, analisamos a relação entre estrutura da vegetação e diversidade de aves utilizando dados de riqueza de aves coletados em um gradiente estrutural de vegetação. Nesta etapa, utilizamos um delineamento amostral que também nos permitiu considerar potenciais efeitos da estrutura da vegetação sobre a detectabilidade das espécies, assim como também calcular as probabilidades de ocupação e detecção para cada espécie separadamente. Os resultados obtidos neste capítulo, para as 38 espécies mais detectadas, mostraram que a riqueza das comunidades e a detecção das espécies de aves podem ser influenciados pela estrutura da vegetação. Apesar da relação entre riqueza de aves e estrutura da vegetação não ter sido positiva e monotônica, como esperávamos inicialmente, houve um discreto aumento do número de espécies de aves nos sítios onde a estrutura vertical da vegetação foi intermediária e também nos sítios onde houve maior presença de vegetação abaixo de $2 \mathrm{~m}$. Quando comparadas as relações da riqueza estimada de espécies (que considera a heterogeneidade de detecção) e as relações que consideraram apenas a riqueza observada (naive), esta última apresentou padrões mais acentuados. Apesar disto, ambas as medidas de diversidade apresentarem resultados qualitativamente semelhantes. Esta diferença nas relações entre estrutura da vegetação e riqueza estimada e observada foi maior principalmente nos dois extremos do gradiente de estrutura vertical da vegetação e também nas áreas com menor presença (ou densidade) de vegetação abaixo de 2 m. Esta comparação, portanto, mostra que nestes extremos dos gradientes de vegetação a detecção 
das espécies pode ser mais baixa, o que poderia refletir diretamente na intensidade dos padrões observados. É importante salientar que estas diferenças foram observadas para o conjunto de espécies mais representadas durante as amostragens, as quais provavelmente são as mais comuns e que apresentam maiores probabilidades de detecção. Se considerarmos todo o conjunto de 140 espécies amostradas durante o estudo, as relações entre estrutura da vegetação e riqueza estimada e observada se inverteriam, sendo a riqueza estimada de espécies bem maior nos extremos dos gradientes e a riqueza observada manteria o mesmo padrão observado para as espécies mais detectadas. Os resultados obtidos nesta análise que inclui todas as espécies necessitam ser confirmados, já que a análise dos dados de espécies com poucos registros nestes modelos de ocupação e e detecção pode ser problemática. Um dos potenciais problemas seria a não convergência das estimativas dos parâmetros de ocupação, o que resulta em uma maior chance de prevermos falsas presenças das espécies mais raras. Uma forma de contornar este problema seria utilizarmos diferentes distribuições a priori para os parâmetros de ocorrência das espécies. Por meio de informações adicionais de diferentes fontes, poderíamos diminuir as incertezas sobre os valores dos parâmetros destas espécies, e isto ajudaria a reduzir os potenciais vieses nestas situações. Além disto, outros estudos que busquem avaliar a composição e dinâmica das comunidades nestes mosaicos vegetacionais também são necessários para um maior entendimento do papel da estrutura da vegetação para a manutenção da diversidade de aves no Cerrado. 


\section{Referências}

Abreu, T. L. S. (2000). Efeito de queimadas sobre a comunidade de aves de Cerrado. PhD thesis, Dissertação de Mestrado - Universidade de Brasília, Brasília, BR.

Accordi, I. A., Barcellos-silveira, A., and Pacheco, J. F. (2003). Bibliografia Digital da Ornitologia Brasileira - I. October, 11(2):245-262.

Accordi, I. A., Barcellos-silveira, A., and Pacheco, J. F. (2005). Bibliografia Digital da Ornitologia Brasileira - IV. October, 11(2):245-262.

Accordi, I. A., Barcellos-silveira, A., and Pacheco, J. F. (2005a). Bibliografia Digital da Ornitologia Brasileira - V. October, 11(2):245-262.

Almeida, M. E. d. C. (2002). Estrutura De Comunidades De Aves Em Áreas De Cerrado Da Região Nordeste Do Estado De São Paulo. PhD thesis, Tese de Doutorado - Universidade Federal de São Carlos, São Carlos, BR.

Antas, P. d. T. Z. (1999). Comunidade De Aves Dos Cerrados Do Planalto Central E Porção Ocidental Do Médio Rio São Francisco. PhD thesis, Tese de Doutorado - Universidade de Brasília, Brasília, BR.

Azpiroz, A. B. and Blake, J. G. (2016). Associations of grassland birds with vegetation structure in the Northern Campos of Uruguay. The Condor, 118(1):12-23.

Banks-Leite, C., Pardini, R., Boscolo, D., Cassano, C. R., Püttker, T., Barros, C. S., and 
Barlow, J. (2014). Assessing the utility of statistical adjustments for imperfect detection in tropical conservation science. Journal of Applied Ecology, 51(4):849-859.

Bates, D., Maechler, M., Bolker, B. M., and Walker, S. (2014). Fitting Linear Mixed-Effects Models using \{lme4\}. Journal Of Statistical Software, 67(1):1-48.

Bibby, C. J., Burgess, N. D., and Hill, D. A. (1992). Bird Census Techniques. Academic Press, San Diego, US.

Blake, J. H. and Loiselle, B. A. (2001). Bird assemblages in second-growth and old-growth forests, Costa Rica: Perspectives from mist nets and point counts. The Auk, 118(2):304326.

Blamires, D., de Oliveira, G., de Souza Barreto, B., and Diniz-Filho, J. A. F. (2008). Habitat use and deconstruction of richness patterns in Cerrado birds. Acta Oecologica, 33(1):97-104.

Bohning-Gaese, K. (1997). Determinants of avian species richness at different spatial scales. Journal of Biogeography, 24(1):49-60.

Bolker, B. and Team, R. D. C. (2016). bbmle: Tools for General Maximum Likelihood Estimation. R package version 1.0.18.

Bolker, B. M., Brooks, M. E., Clark, C. J., Geange, S. W., Poulsen, J. R., Stevens, M. H. H., and White, J. S. S. (2009). Generalized linear mixed models: a practical guide for ecology and evolution. Trends in Ecology and Evolution, 24(3):127-135.

Bonter, D. N., Brooks, E. W., and Donovan, T. M. (2008). What are we missing with only ground-level mist nets? Using elevated nets at a migration stopover site. Journal of Field Ornithology, 79(3):314-320.

Borges, P. P., de Andrade Oliveira, K. A. F., Machado, K. B., Vaz, Ú. L., da Cunha, H. F., and Nabout, J. C. (2015). Tendências e lacunas da literatura científica sobre o bioma Cerrado:Uma análise cienciométrica. Neotropical Biology and Conservation, 10(1):2-8. 
Borges, S. H. (2008). Bibliografia ornitológica do Brasil - Dissertações e teses no período de 1970 à 2005. Revista Brasileira de Ornitologia, 16(1):82-98.

Boulinier, T. B., Nichols, J. D. N., Sauer, J., and Hines, J. E. (1998). Estimating Species Richness : the Importance of Heterogeneity in Species Detectability. Ecology, 79(3):10181028.

Braz, V. D. S. (2008). Ecologia e conservação das aves campestres do bioma Cerrado. Tese de Doutorado. PhD thesis, Tese de Doutorado - Universidade de Brasília, Brasília, BR.

Burnham, K. and Overton, W. (1979). Robust estimation of population size when capture probabilities vary among animals. Ecology, 60(5):927-936.

Carrillo-Rubio, E., Kéry, M., Morreale, S. J., Sullivan, P. J., Gardner, B., Cooch, E. G., and Lassoie, J. P. (2014). Use of multispecies occupancy models to evaluate the response of bird communities to forest degradation associated with logging. Conservation Biology, 28(4):1034-1044.

Carvalho, F. M. V., De Marco, P., and Ferreira, L. G. (2009). The Cerrado into-pieces: Habitat fragmentation as a function of landscape use in the savannas of central Brazil. Biological Conservation, 142(7):1392-1403.

Cavarzere, V. (2013). Does the reproductive season account for more records of birds in a marked seasonal climate landscape in the state of São Paulo, Brazil? Papeis Avulsos de Zoologia, 53(18):253-260.

Cody, M. L. (1985). Habitat Selection in Birds. Number 1. Academic Press, Orlando, US.

Costa, L. M. and Rodrigues, M. (2012). Bird community structure and dynamics in the campos rupestres of southern Espinhaço Range, Brazil: Diversity, phenology and conservation. Revista Brasileira de Ornitologia, 20(2):132-147.

Coutinho, L. M. (1978). O conceito de cerrado. Revista brasileira de Botânica, 1:17-23. 
Cueto, V. R. and de Casenave, J. L. (1999). Determinants of bird species richness: role of climate and vegetation structure at a regional scale. Journal of Biogeography, 26(1):487492.

Curcino, A., De Sant'Ana, C. E. R., and Heming, N. M. (2007). Comparação de três comunidades de aves na região de Niquelândia, GO. Revista Brasileira de Ornitologia, $15(4): 574-584$.

da Silva, J. M. C. (1995). Avian inventory of the cerrado region, South America: implications for biological conservation. Bird Conservation International, 5:291-304.

da Silva, J. M. C. (1997). Endemic bird species and conservation in the Cerrado Region, South America. Biodiversity and Conservation, 6:435-450.

da Silva, J. M. C. and Bates, J. M. (2002). Biogeographic Patterns and Conservation in the South American Cerrado: A Tropical Savanna Hotspot. BioScience, 52(3):225.

Díaz, L. (2006). Influences of forest type and forest structure on bird communities in oak and pine woodlands in Spain. Forest Ecology and Management, 223(1-3):54-65.

Dorazio, R. M. and Royle, J. A. (2005). Estimating Size and Composition of Biological Communities by Modeling the Occurrence of Species. Jounal of the American Statistical Association, 100(407):389-398.

Doughty, C. E., Faurby, S., and Svenning, J. C. (2016). The impact of the megafauna extinctions on savanna woody cover in South America. Ecography, 39(2):213-222.

Elphick, C. S. (2008). How you count counts: The importance of methods research in applied ecology. Journal of Applied Ecology, 45(5):1313-1320.

Ferger, S. W., Schleuning, M., Hemp, A., Howell, K. M., and Böhning-Gaese, K. (2014). Food resources and vegetation structure mediate climatic effects on species richness of birds. Global Ecology and Biogeography, 23(5):541-549. 
Fieker, C. Z. (2012). Estruturação das assembléias de aves que utilizam diferentes fisionomias de Cerrado na Estação Ecológica de Itirapina, São Paulo. PhD thesis, Dissertação de Mestrado - Universidade Federal de São Carlos, São Carlos, BR.

Field, C., Behrenfeld, M. J., Randerson, J. T., and Falkowski, P. (1998). Primary Production of the Biosphere: Integrating Terrestrial and Oceanic Components. Science, 281(5374):237-240.

Fisher, R. A., Corbet, S., and Williams, C. B. (1943). The Relation Between the Number of Species and the Number of Individuals in a Random Sample of an Animal Population. Journal of Animal Ecology, 12(1):42-58.

Frederico, S. (2010). O Novo Tempo do Cerrado: Expansão dos fronts agrícolas e controle do sistema de armazenamento de grãos. Editora São Paulo: Anna Blume.

Fry, C. H. (1970). Ecological distribution of birds in north-eastern Mato Grosso state, Brazil. Anais da Academia Brasileira de Ciências, 42:275-318.

Gelman, A. (2003). A Bayesian Formulation of Exploratory Data Analysis and Goodnessof-fit Testing. International Statistical Review, 71(2):369-382.

Gimenez, O., Viallefont, A., Charmantier, A., Pradel, R., Cam, E., Brown, C. R., Anderson, M. D., Brown, M. B., Covas, R., and Gaillard, J.-M. (2008). The risk of flawed inference in evolutionary studies when detectability is less than one. The American naturalist, 172(3):441-448.

Goodland, R. (1971). A physiognomic analysis of the Cerrado vegetation of Central Brasil. Journal of Ecology, 59(2):411-419.

Gotelli, N. J. and Colwell, R. K. (2001). Quantifying biodiversity: Procedures and pitfalls in the measurement and comparison of species richness. Ecology Letters, 4(4):379-391.

Gu, W. and Swihart, R. K. (2004). Absent or undetected? Effects of non-detection of species occurrence on wildlife-habitat models. Biological Conservation, 116(2):195-203. 
Hurlbert, A. H. (2004). Species-energy relationships and habitat complexity in bird communities. Ecology Letters, 7(8):714-720.

IBAMA (2003). Parque Nacional Grande Sertão Veredas: Plano de Manejo.

Jankowski, J. E., Merkord, C. L., Rios, W. F., Cabrera, K. G., Revilla, N. S., and Silman, M. R. (2013). The relationship of tropical bird communities to tree species composition and vegetation structure along an Andean elevational gradient. Journal of Biogeography, 40(5):950-962.

Johnson, M. a., Saraiva, P. M., and Coelho, D. (1999). The role of gallery forests in the distribution of cerrado mammals. Revista Brasileira de Biologia, 59(3):421-427.

Kellner, K. (2016). jagsUI: A Wrapper Around 'rjags' to Streamline 'JAGS'Analyses. R package version 1.4.2.

Kéry, M. and Royle, J. A. (2016). Applied Hierarchical Modeling in Ecology. Analysis of distribution, abundance and species richness in $R$ and BUGS: Volume 1: Prelude and Static Models. Academic Press, 1st edition.

Kinas, P. G. and Andrade, H. A. (2010). Introdução à Análise Bayesiana (com R). MaisQnada, Porto Alegre, BR.

Kissling, W. D., Field, R., and Böhning-Gaese, K. (2008). Spatial patterns of woody plant and bird diversity: Functional relationships or environmental effects? Global Ecology and Biogeography, 17(3):327-339.

Kissling, W. D., Rahbek, C., and Böhning-Gaese, K. (2007). Food Plant Diversity as Broad-Scale Determinant of Avian Frugivore Richness. Proceedings: Biological Sciences, 274(1611):799-808.

Klink, C. A. and MAchado, R. B. (2005). A conservação do Cerrado brasileiro. Megadiversidade, 1(1):147-155. 
Kutt, A. S. and Martin, T. G. (2010). Bird foraging height predicts bird species response to woody vegetation change. Biodiversity and Conservation, 19(8):2247-2262.

Lins, L. V. (1994). O Papel Da Mata Ciliar Na Estrutura De Uma Comunidade De Aves Do Cerrado (Brasilia, Df). PhD thesis, Dissertaçãode Mestrado - Universidade Federal de Minas Gerais, Belo Horizonte, BR.

MacArthur, R. H. and MacArthur, J. W. (1961). On bird species diversity. Ecology, $42(3): 594-598$.

MacArthur, R. H., MacArthur, J. W., and Preer, J. (1962). On Bird Species Diversity . II . Prediction of Bird Census from Habitat Measurements. The American Naturalist, 96(888):167-174.

Macedo, R. H. F. (2002). The Avifauna: Ecology, Biogeography, and Behavior. In Oliveira, P. and Marquis, R. J., editors, The Cerrados of Brazil: ecology and natural history of a neotropical savanna, number chapter 5, pages 242-265. Columbia University Press, New York.

MacKenzie, D. I., Nichols, J. D., Hines, J. E., Knutson, M. G., and Franklin, A. B. (2003). Estimating site occupancy, colonization, and local extinction when a species is detected imperfectly. Ecology, 84(8):2200-2207.

Mackenzie, D. I., Nichols, J. D., Lachman, G. B., Droege, S., Royle, J. A., and Langtimm, C. A. (2002). Estimating Site Occupancy Rates When Detection Probabilities Are Less Than One. Ecology, 83(8):2248-2255.

MacKenzie, D. I., Nichols, J. D., Royle, J. A., Pollock, K. H., Bailey, L. L., and Hines, J. E. (2006). Occupancy Estimation and Modeling: Inferring Patterns and Dynamics of Species Occurrence, volume 1. Academic Press, 1st edition.

Marini, M. Â. and Garcia, F. I. (2005). Conservação de aves no Brasil. Megadiversidade, 1(1):95-102. 
Martins, F. D. C. (2007). Estrutura de comunidades de aves em remanescentes de Floresta Estacional Decidual na região do Vale do Rio Paranã - GO e TO. PhD thesis, Tese de Doutorado - Tese de Doutorado - Universidade de Brasília, Brasília, BR.

McNew, L. B. and Handel, C. M. (2015). Evaluating species richness: Biased ecological inference results from spatial heterogeneity in detection probabilities. Ecological Applications, 25(6):1669-1680.

Mihaljevic, J. R. and Johnson, M. B. J. P. T. J. (2015). Using multispecies occupancy models to improve the characterization and understanding of metacommunity structure. Ecology, 96(7):1783-1792.

Morandini, R. S. (2013). Diversidade funcional das aves do Cerrado com simulações da perda de fisionomias campestres e espécies ameaçadas: implicações para a conservação. PhD thesis, Dissertação de Mestrado - Universidade de São Paulo, São Paulo, BR.

Motta Jr., J. C. (1990). Estrutura trófica e composição das avifaunas de três hábitats terrestres na região central do estado de São Paulo. Ararajuba, (1):65-71.

Motta-Junior, J. C., Granzinolli, M. A. M., and Develey, P. F. (2008). Aves da Estação Ecológica de Itirapina, estado de São Paulo , Brasil Material e Métodos. Biota Neotrop$i c a, 8(3): 207-227$.

Myers, N., Mittermeier, R. A., Mittermeier, C. G., da Fonseca, G. A. B., and Kent, J. (2000). Biodiversity hotspots for conservation priorities. Nature, 403(6772):853-858.

Nogueira, C., Ribeiro, S., Costa, G. C., and Colli, G. R. (2011). Vicariance and endemism in a Neotropical savanna hotspot: Distribution patterns of Cerrado squamate reptiles. Journal of Biogeography, 38(10):1907-1922.

Oliveira-Filho, A. T. and Ratter, J. T. (2002). Vegetation physiognomies and woody flora o the cerrado biome. In Oliveira, P. S. and Marquis, R. J., editors, The Cerrados of Brazil: Ecology and Natural History of a Neotropical Savanna, pages 91-120. Columbia University Press, New York. 
Olmos, F. and Brito, G. R. R. (2007). Aves da região da Barragem de Boa Esperança, médio rio Parnaíba, Brasil. Revista Brasileira de Ornitologia, 15(1):37-52.

Orians, G. H. (1969). The Number of Bird Species in Some Tropical Forests. Ecology, $50(5): 783-801$.

Otis, D. L., Burnham, K. P., White, G. C., and Anderson, D. R. (1978). Statistical Inference from Capture Data on Closed Animal Populations. Wildlife Monographs, (62):3135.

Pacheco, J. F. and Olmos, F. (2006). As aves do Tocantins 1: Região sudeste. Revista Brasileira de Ornitologia, 14(2):85-100.

Pascoal, J. O., Amorim, M. P., Martins, M. M., Melo, C., da Silva Júnior, E. L., Ogrzewalska, M., Labruna, M. B., and Szabó, M. P. J. (2013). Ticks on birds in a savanna (Cerrado) reserve on the outskirts of Uberlândia, Minas Gerais, Brazil . Carrapatos em aves de uma reserva do Cerrado na periferia de Uberlândia, Minas Gerais, Brasil, $22(1): 46-52$.

Piratelli, A. (2003). Mesh size and bird capture rates in Mato Grosso do Sul State, Brazil. Brazilian Journal of Biology, 63(1):105-111.

Piratelli, A. and Blake, J. G. (2006). Bird Communities of the Southeastern Cerrado Region , Brazil. Ornitologia Neotropical, 17:213-225.

Posso, S. R., de Freitas, M. N., Bueno, F. A., Mizobe, R. S., Filho, J. C. M., and RagusaNeto, J. (2013). Avian composition and distribution in a mosaic of cerrado habitats (RPPN Parque Ecológico João Basso) in Rondonópolis, Mato Grosso, Brazil. Revista Brasileira de Ornitologia, 21(4):243-256.

Poulsen, B. O. (2002). Avian richness and abundance in temperate Danish forests: Tree variables important to birds and their conservation. Biodiversity and Conservation, 11(9):1551-1566.

Preston, F. W. (1948). The Commonness, And Rarity, of Species. Ecology, 29(3):254. 
Price, B., McAlpine, C. A., Kutt, A. S., Ward, D., Phinn, S. R., and Ludwig, J. A. (2013). Disentangling How Landscape Spatial and Temporal Heterogeneity Affects Savanna Birds. PLoS ONE, 8(9).

Ratter, J. A., Ribeiro, J. F., and S., B. (1997). The Brazilian Cerrado Vegetation and Threats to its Biodiversity. Annals of Botany, 80:223-230.

Redford, K. H. and Fonseca, G. A. B. (1986). The Role of Gallery Forests in th Zoogeography of the Cerrado's Non-volant Mammalian Fauna. Biotropica, 18(2):126-135.

Ribeiro, J. F. and Walter, B. M. T. (1998). Fitofisionomias do bioma Cerrado. In Sano, S.M. and Almeida, S., editor, Cerrado : ambiente e flora, pages 87-166. Embrapa CPAC.

Roberts, J. P. and Schnell, G. D. (2006). Comparison of survey methods for wintering grassland birds. Journal of Field Ornithology, 77(1):46-60.

Rodrigues, M. and Faria, L. D. P. (2007). Species Richness of Understory Birds in Different Habitats of the Cerrado Region of Southeastern Brazil. Tropical Ecology, 13:101-110.

Rotenberry, J. T. (1985). The role of habitat in avian community composition: physiognomy or floristics? Oecologia, 67(2):213-217.

Ruiz-Gutiérrez, V. and Zipkin, E. F. (2011). Detection biases yield misleading patterns of species persistence and colonization in fragmented landscapes. Ecosphere, 2(5):art61.

Schoener, T. (1968). Sizes of feeding territories among birds. Ecology, 49(1):123-141.

Sendoda, A. M. C. (2009). Efeito do manejo de fogo sobre comunidades de aves em campos sujos no Parque Nacional das Emas, GO/MS, Cerrado central. Dissertação de Mestrado. $\mathrm{PhD}$ thesis.

Seymour, C. L. and Dean, W. R. J. (2010). The influence of changes in habitat structure on the species composition of bird assemblages in the southern Kalahari. Austral Ecology, $35(5): 581-592$. 
Silva, G. B. M. (2004). Estimativas Da Diversidade Da Avifauna Em Fitofisionomias Do Bioma Cerrado Na Estação De Pesquisa E Desenvolvimento Ambiental ( Epda) Galheiro , Perdizes , Mg. PhD thesis, Dissertação de Mestrado - Universidade Federal de Lavras, Lavras, BR.

Simon, M. F., Grether, R., de Queiroz, L. P., Skema, C., Pennington, R. T., and Hughes, C. E. (2009). Recent assembly of the Cerrado, a neotropical plant diversity hotspot, by in situ evolution of adaptations to fire. Proceedings of the National Academy of Sciences, 106(48):20359-20364.

Skowno, A. L. and Bond, W. J. (2003). Bird community composition in an actively managed savanna reserve, importance of vegetation structure and vegetation composition. Biodiversity and Conservation, 12(11):2279-2294.

Spera, S. A., Galford, G. L., Coe, M. T., Macedo, M. N., and Mustard, J. F. (2016). Landuse change affects water recycling in brazil's last agricultural frontier. Global Change Biology, pages $\mathrm{n} / \mathrm{a}-\mathrm{n} / \mathrm{a}$.

Srivastava, D. S. and Lawton, J. H. (1998). Why More Productive Sites Have More Species : An Experimental Test of Theory Using Tree-Hole Communities. The American Naturalist, 152(4):510-529.

Stauffer, H. B., Ralph, C. J., and Miller, S. L. (2002). Incorporating detection uncertainty into presence-absence surveys for Marbled Murrelet. In Scott, J., Heglund, P., Morrison, M., Haufler, J., Raphael, M., Wall, W., and Samson, F., editors, Predicting Species Occurrences: Issues of Accuracy and Scale, number 1992, pages 357-365. Island Press, Washington, DC.

Stotz, D. F., Fitzpatrick, J. W., Parker III, T. A., and Moskovits, D. K. (1996). Neotropical Birds: Ecology and Conservation. University of Chicago Press, Chicago, US.

Sutherland, C., Brambilla, M., Pedrini, P., and Tenan, S. (2016). A multiregion community model for inference about geographic variation in species richness. Methods in Ecology and Evolution, pages 1-9. 
Terborgh, J. (1977). Bird Species Diversity on an Andean Elevational Gradient. Ecology, 58(5):1007-1019.

Tews, J., Brose, U., Grimm, V., Tielbörger, K., Wichmann, M. C., Schwager, M., and Jeltsch, F. (2004). Animal species diversity driven by habitat heterogeneity/diversity: the importance of keystone structures. Journal of Biogeography, 31(1):79-92.

Tolesano-Pascoli, G. V., Torga, K., Franchin, A. G., Ogrzewalska, M., Gerardi, M., Olegário, M. M. M., Labruna, M. B., Szabó, M. P. J., and Marçal Júnior, O. (2010). Ticks on birds in a forest fragment of Brazilian cerrado (savanna) in the municipality of Uberlândia, State of Minas Gerais, Brazil. Revista brasileira de parasitologia veterinaria = Brazilian journal of veterinary parasitology : Orgao Oficial do Colegio Brasileiro de Parasitologia Veterinaria, 19(4):244-248.

Tubelis, D. P. and Cavalcanti, R. B. (2001). Community similarity and abundance of bird species in open habitats of a central Brazilian Cerrado. Ornitologia Neotropical, $12: 57-73$.

Tubelis, D. P., Cowling, A., and Donnelly, C. (2004). Landscape supplementation in adjacent savannas and its implications for the design of corridors for forest birds in the central Cerrado, Brazil. Biological Conservation, 118(3):353-364.

Valadão, R. M. (2012). As aves da Estação Ecológica Serra das Araras, Mato Grosso, Brasil. Biota Neotropica, 12(3):263-281.

Venables, W. N. and Ripley, B. D. (2002). Modern Applied Statistics With S. Technometrics, 45(1):111-111.

Verner, J. and Ritter, L. V. (1985). A comparison of transects and spot mapping in oak-pine wooldands of California. The Condor, 90(1):401-419.

Wiens, J. A. and Rotenberry, J. T. (1981). Habitat Associations and Community Structure of Birds in Shrubsteppe Environments. Source: Ecological Monographs Ecological Monographs, 51(11):21-42. 
Wilson, M. F. (1974). Avian Community Organization and Habitat Structure. Ecology, 55(5):1017-1029.

Zipkin, E. F., Royle, J., Dawson, D. K., and Bates, S. (2010). Multi-species occurrence models to evaluate the effects of conservation and management actions. Biological Conservation, 143(2):479-484.

Zuur, A., Ieno, E., Walker, J., Saveliev, A., and Smith, G. (2009). Mixed Effects Models and Extensions in Ecology with R. Springer, New York. 
Appendix 



\section{Appendix A}

\section{A.1 Databases and keywords used in secondary data search}

We chosen keywords within some categories of interest that allow us to find studies within our scope. We combined keywords of the same category using "OR" and different categories using "AND" boolean operators, which allows us search any word present of one category, but the studies in demand necessarily had to use at least one word of each category. In the first two databases (Web of Science and Scopus) we choose keywords in four categories of interest (vegetation structure, biome, taxonomic group and community properties)(Table 3), but in Scielo database we used keywords in just three categories (vegetation structure, taxonomic group and community properties), by a limitation in the search tool to include more than three keywords search fields (Table 3). Specifically in Scopus database, we had to perform three separate searches using all the keywords of

biome, taxonomic group and community properties categories, but separated subsets of vegetation structure keywords, because the search tool of this database presented a limit in the quantity of characters allowed in each search field (Table 3). 
Table A.1 - Database search results, search data and key words used in each one.

\begin{tabular}{|c|c|}
\hline $\begin{array}{l}\text {-Web of Science: } \\
327 \text { articles }\end{array}$ & \\
\hline Date: 26 November 2013 & \\
\hline Vegetation structure & $\begin{array}{l}\text { "vegeta* structure", "habitat* structure","vegeta* } \\
\text { height" } \\
\text { "vegeta* complexity", "vegeta* physiognom*", } \\
\text { "phytophysiognom*", "phitophysiognom*", *physiog- } \\
\text { nom*, } \\
\text { "vegeta* diversity", "habitat* structur*", "vegeta* pro- } \\
\text { file", } \\
\text { "habitat* complexit*", "habitat* physiognom,", } \\
\text { "habitat* heterogeneit*", "habitat* height*", } \\
\text { "habitat* diversit*", "structur* complexit*", } \\
\text { "structur* heterogeneit*", "structur* height*", } \\
\text { "structur* diversit*", "foliage height*", "foliage profile", } \\
\text { "foliage diversit*" }\end{array}$ \\
\hline Biome & cerrado* $^{*}$, savanna*, savannah*, woodland*, grassland* \\
\hline Taxonomic group & bird $^{*}$, avifauna, avian \\
\hline Community property & $\begin{array}{l}\text { diversity, "species richness", richness, "species number", } \\
\text { "species abundance*" }\end{array}$ \\
\hline -Scopus: 138 articles & \\
\hline Date: 28 November 2013 & \\
\hline Vegetation Structure & \\
\hline Search 1 & $\begin{array}{l}\text { "vegeta* structure", "habitat* structure", "vegeta* } \\
\text { height", } \\
\text { "vegeta* complexity", "vegeta* physiognom*", } \\
\text { "phytophysiognom*", "phitophysiognom*", *physiog- } \\
\text { nom*, } \\
\text { "vegeta* diversity", "habitat* structur*", "vegeta* pro- } \\
\text { file" }\end{array}$ \\
\hline Search 2 & $\begin{array}{l}\text { "habitat* complexit*", "habitat* physiognom*", } \\
\text { "habitat* heterogeneit*", "habitat* height*", } \\
\text { "habitat* diversit*", "structur* complexit*", } \\
\text { "structur* heterogeneit*", "structur* height*", } \\
\text { "structur* diversit*" }\end{array}$ \\
\hline Search 3 & "foliage height*", "foliage profile", "foliage diversit*" \\
\hline Biome & $\begin{array}{l}\text { cerrado*, savanna*, savannah*, woodland*, } \\
\text { grassland* }\end{array}$ \\
\hline Taxonomic group & bird $^{*}$, avifauna, avian \\
\hline Community property & $\begin{array}{l}\text { diversity, "species richness", richness, } \\
\text { "species number", "species abundance*" }\end{array}$ \\
\hline -Scielo: 25 articles & \\
\hline Date: 10 December 2013 & \\
\hline Biome & cerrado*$^{*}$, savan $^{*}$, woodland ${ }^{*}$, grassland* ${ }^{*}$ campo $^{*}$ \\
\hline Taxonomic Group & aves, bird*, avifauna, avian \\
\hline Community property & $\begin{array}{l}\text { diversi*, riqueza, richness, } \\
\text { "riqueza de espécies", "species richness", "species num- } \\
\text { ber*", } \\
\text { abundância, abundance*, "abundância de espécies", } \\
\text { "species abundance". comunidade community }\end{array}$ \\
\hline
\end{tabular}


Table A.2 - Universities consulted for thesis and dissertations including "aves" and "cerrado" in the abstract.

\begin{tabular}{|c|c|c|c|c|}
\hline University Code & University Name & State & \multicolumn{2}{|c|}{ Studies Date } \\
\hline USP & Universidade de São Paulo & SP & 97 & $22 / 01 / 14$ \\
\hline UNICAMP & Universidade de Campinas & $\mathrm{SP}$ & 8 & $23 / 01 / 14$ \\
\hline UNESP & $\begin{array}{l}\text { Universidade Estadual Paulista } \\
\text { Campi: S. J. Rio Preto, Botu- } \\
\text { catu, Rio Claro }\end{array}$ & $\mathrm{SP}$ & 8 & $11 / 02 / 14$ \\
\hline UFSCAR & $\begin{array}{l}\text { Universidade Federal de São Car- } \\
\text { los }\end{array}$ & SP & 35 & $09 / 02 / 14$ \\
\hline UFMG & $\begin{array}{l}\text { Universidade Federal de Minas } \\
\text { Gerais }\end{array}$ & MG & 4 & $23 / 01 / 14$ \\
\hline UFU & $\begin{array}{l}\text { Universidade Federal de Uberlân- } \\
\text { dia }\end{array}$ & MG & 65 & $09 / 02 / 14$ \\
\hline UFOP & $\begin{array}{l}\text { Universidade Federal de Ouro } \\
\text { Preto }\end{array}$ & MG & 4 & $11 / 02 / 14$ \\
\hline UFV & Universidade Federal de Viçosa & MG & 35 & $11 / 02 / 14$ \\
\hline UNB & Universidade de Brasília & DF & 91 & $23 / 01 / 14$ \\
\hline UFG & Universidade Federal de Goiás & GO & 78 & $23 / 01 / 14$ \\
\hline UFF & Universidade Federal Fluminense & RJ & 6 & $09 / 02 / 14$ \\
\hline UERJ & $\begin{array}{l}\text { Universidade Estadual do Rio de } \\
\text { Janeiro }\end{array}$ & RJ & 2 & $11 / 02 / 14$ \\
\hline UFRJ & $\begin{array}{l}\text { Universidade Federal do Rio de } \\
\text { Janeiro }\end{array}$ & RJ & 152 & $11 / 02 / 14$ \\
\hline UFMA & $\begin{array}{l}\text { Universidade Federal do Maran- } \\
\text { hão }\end{array}$ & MA & 2 & $11 / 02 / 14$ \\
\hline UFPI & Universidade Federal do Piauí & PI & 0 & $11 / 02 / 14$ \\
\hline
\end{tabular}


Table A.3 - List of regionally important publications scanned by us, with volumes checked, time period of the search and number of studies selected by us.

\begin{tabular}{lcc}
\hline Publication & Volumes visited & Time period \\
\hline Lundiana & $01-11$ & $1982-2013$ \\
Iheringia & $89-104$ & $2000-2014$ \\
Revista Brasileira de Biologia* & $1-60$ & $1971-2001$ \\
Brazilian Journal of Biology* & $61-74$ & $2001-2014$ \\
Checklist & $01-10$ & $2005-2014$ \\
Cotinga & $01-36$ & $1994-2014$ \\
Biota Neotropica & $01-14$ & $2001-2014$ \\
Ararajuba* & $1-12$ & $1990-2004$ \\
Revista Brasileira de Ornitologia* & $13-22$ & $2005-2014$ \\
Papéis Avulsos de Zoologia & $42-54$ & $2002-2014$ \\
Revista Brasileira de Zoologia & $01-25$ & $1982-2008$ \\
\hline
\end{tabular}

\section{A.2 Detailed description of surveys locations}

Table A.4 - List of all independent observations used in our study, with their ID and position in Figure 1, Data base and study where the data were published, scientific magazine or academic publication level, geographical coordinates, habitat physiognomy sampled, census method and effort in hours and the number of species registered.

ID Base Study Lat Long Phyto MethodEffort Bird

\begin{tabular}{|c|c|c|c|c|c|c|c|c|}
\hline & & & & & & & (h) & spp. \\
\hline A & Website & Motta Jr. 1990 & $-21,5800$ & $-47,5200$ & $\mathrm{~S}$ & $\mathrm{~T}$ & 54.0 & 77 \\
\hline B & UFMG & Lins, L.V. 1994 & $-15,5641$ & $-47,5307$ & $\mathrm{~S}$ & $\mathrm{~N}$ & 192.0 & 30 \\
\hline B & UFMG & Lins, L.V. 1994 & $-15,5641$ & $-47,5307$ & $\mathrm{~S}$ & $\mathrm{P}$ & 32.0 & 47 \\
\hline \multirow[t]{2}{*}{ B } & personal & Tubelis and & $-15,4080$ & $-47,5750$ & G & $\mathrm{P}$ & 10.66 & 18 \\
\hline & & $\begin{array}{l}\text { Cavalcanti } \\
2001\end{array}$ & & & & & & \\
\hline \multirow[t]{3}{*}{ B } & personal & Tubelis and & $-15,4080$ & $-47,5750$ & G & $\mathrm{P}$ & 16.0 & 36 \\
\hline & & Cavalcanti & & & & & & \\
\hline & & 2001 & & & & & & \\
\hline
\end{tabular}




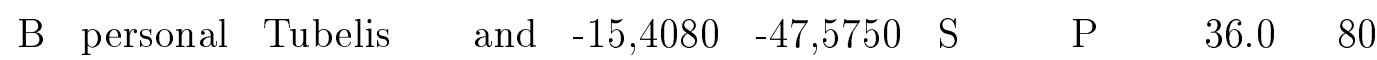
Cavalcanti

2001

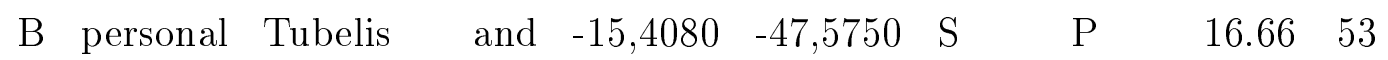
Cavalcanti

2001

$\begin{array}{lllllllll}\text { C UNB } & \text { Antas, } & \text { P.T.Z. } & -15,4080 & -47,5750 & \mathrm{~S} & \mathrm{~N} & 40.0 & 9\end{array}$ 1999

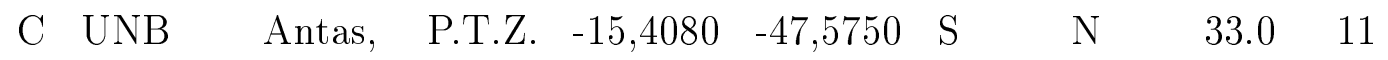
1999

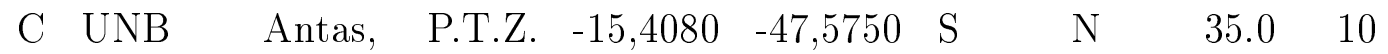
1999

$\begin{array}{lllllllll}\text { C UNB } & \text { Antas, } & \text { P.T.Z. } & -15,4080 & -47,5750 & \mathrm{~S} & \mathrm{P} & 5.0 & 31\end{array}$ 1999

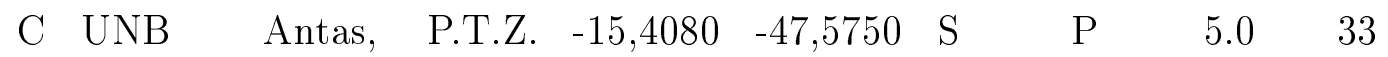
1999

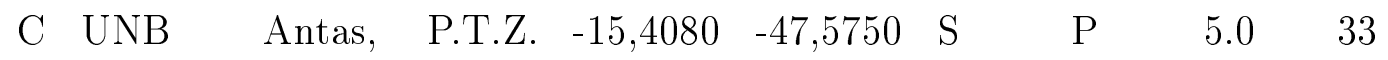
1999

$\begin{array}{lllllllll}\text { C } & \text { UNB } & \text { Braz } 2008 & -15,4080 & -47,5750 & \text { G } & \text { T } & 81.5 & 70\end{array}$

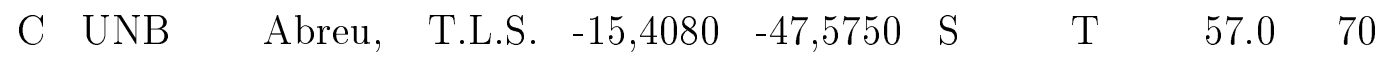
2000

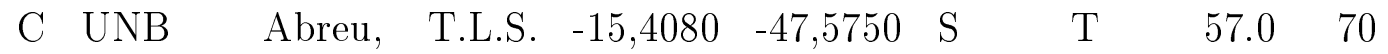
2000

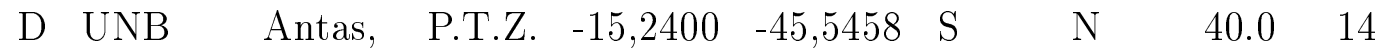
1999

$\begin{array}{lllllllll}\text { D UNB } & \text { Antas, } & \text { P.T.Z. } & -15,2400 & -45,5458 & \mathrm{~S} & \mathrm{~N} & 17.5 & 8\end{array}$ 1999

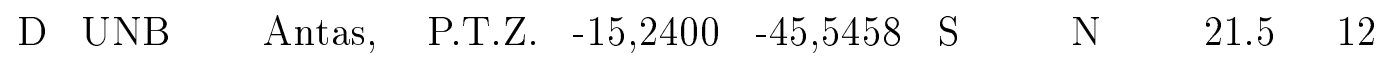
1999 


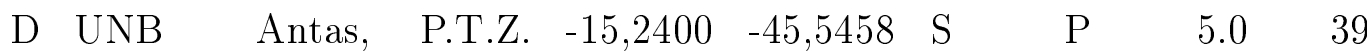
1999

$\begin{array}{llllllll}\text { D UNB Antas, } & \text { P.T.Z. } & -15,2400 & -45,5458 & \mathrm{~S} & \mathrm{P} & 3.0 & 41\end{array}$ 1999

$\begin{array}{llllllll}\text { D UNB Antas, P.T.Z. } & -15,2400 & -45,5458 & \mathrm{~S} & \mathrm{P} & 3.0 & 39\end{array}$ 1999

$\begin{array}{lllllllll}\text { E UNB } & \text { Antas, } & \text { P.T.Z. } & -15,5620 & -46,3110 & \mathrm{~S} & \mathrm{~N} & 14.5 & 6\end{array}$ 1999

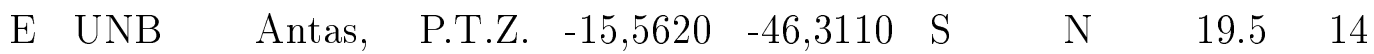
1999

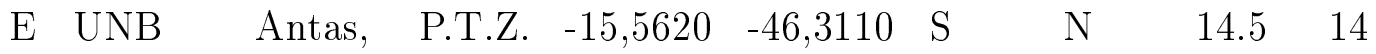
1999

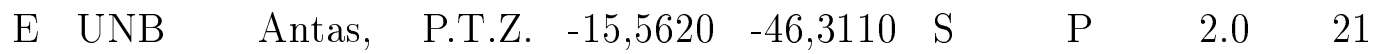
1999

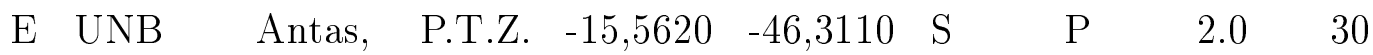
1999

$\begin{array}{lllllllll}\text { E UNB } & \text { Antas, } & \text { P.T.Z. } & -15,5620 & -46,3110 & \mathrm{~S} & \mathrm{P} & 2.0 & 27\end{array}$ 1999

$\begin{array}{lllllllll}\text { F } & \text { UFSCAR Almeida } 2002 & -21,3000 & -47,4000 & \mathrm{~F} & \mathrm{P} & 20.0 & 48\end{array}$

$\begin{array}{llllllll}\text { F } & \text { UFSCAR Almeida } 2002 & -21,4000 & -47,5000 & \text { F } & \text { P } & 20.0 & 34\end{array}$

$\begin{array}{llllllll}\text { F } & \text { UFSCAR Almeida } 2002 & -21,4000 & -47,5000 & \mathrm{~F} & \mathrm{P} & 20.0 & 49\end{array}$

$\begin{array}{lllllllll}\text { G } & \text { UFLA } & \text { Silva } 2004 & -19,1406 & -47,0831 & \text { F } & \text { N } & 36.0 & 28\end{array}$

$\begin{array}{lllllllll}\text { G } & \text { UFLA } & \text { Silva } 2004 & -19,1406 & -47,0831 & \text { G } & \text { N } & 36.0 & 45\end{array}$

$\begin{array}{llllllllll}\text { G } & \text { UFLA } & \text { Silva } 2004 & -19,1406 & -47,0831 & \mathrm{~S} & \mathrm{~N} & 36.0 & 37\end{array}$

$\begin{array}{lllllllll}\text { G } & \text { UFLA } & \text { Silva } 2004 & -19,1406 & -47,0831 & \mathrm{~S} & \mathrm{~N} & 36.0 & 33\end{array}$

$\begin{array}{lllllllll}\text { G } & \text { UFLA } & \text { Silva } 2004 & -19,1406 & -47,0831 & \text { F } & \text { T } & 60.0 & 115\end{array}$

$\begin{array}{lllllllll}\text { G } & \text { UFLA } & \text { Silva } 2004 & -19,1406 & -47,0831 & \text { G } & \text { T } & 60.0 & 149\end{array}$

$\begin{array}{lllllllll}\text { G } & \text { UFLA } & \text { Silva } 2004 & -19,1406 & -47,0831 & \mathrm{~S} & \mathrm{~T} & 60.0 & 161\end{array}$

$\begin{array}{llllllllll}\text { G } & \text { UFLA } & \text { Silva } 2004 & -19,1406 & -47,0831 & \mathrm{~S} & \mathrm{~T} & 60.0 & 156\end{array}$ 


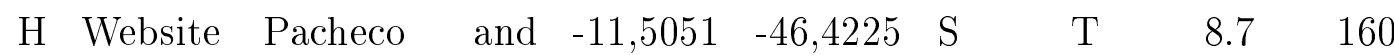
Olmos 2006

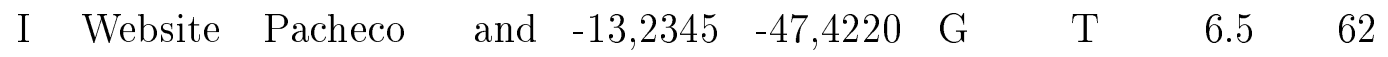
Olmos 2006

$\begin{array}{lllllllll}\text { J Website Pacheco and } & -12,4005 & -47,5357 & \mathrm{~S} & \mathrm{~T} & 10.5 & 148\end{array}$ Olmos 2006

$\begin{array}{llllllll}K & \text { personal Piratelli and } & -21,2500 & -52,0300 & \mathrm{~S} & \mathrm{~N} & 375.0 & 67\end{array}$ Blake 2006

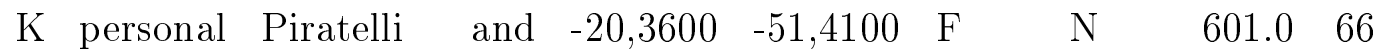
Blake 2006

$\begin{array}{lllllllll}\text { L Website Curcino et al } & -14,0934 & -48,2006 & \mathrm{~S} & \mathrm{P} & 10.0 & 80\end{array}$ 2007

$\begin{array}{llllllll}\text { M UNB } & \text { Martins } 2007 & -14,3119 & -46,4712 & \mathrm{~S} & \mathrm{~T} & 90.0 & 31\end{array}$

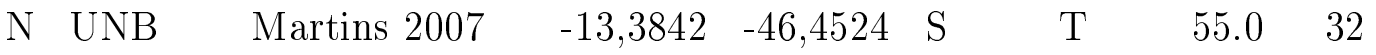

$\begin{array}{lllllllll}\text { O UNB } & \text { UNartins } 2007 & -12,5455 & -47,3659 & \mathrm{~S} & \mathrm{~T} & 105.0 & 56\end{array}$

$\begin{array}{lllllllll}\mathrm{P} & \text { personal Rodrigues and } & -17.3894 & -43.8961 & \mathrm{~S} & \mathrm{~N} & 100.8 & 66\end{array}$ Faria 2007

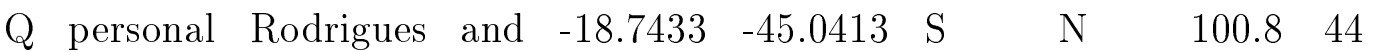
Faria 2007

$\begin{array}{llllllll}R & \text { personal Rodrigues and } & -17.0291 & -45.9016 & F & N & 100.8 & 36\end{array}$ Faria 2007

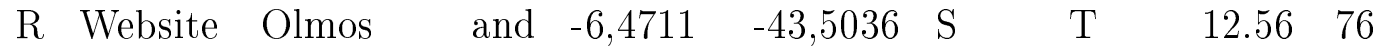
Brito 2007

$\begin{array}{llllllll}\mathrm{R} & \text { Website Olmos and } & -6,4711 & -43,5036 & \mathrm{~S} & \mathrm{~T} & 10.45 & 70\end{array}$ Brito 2007

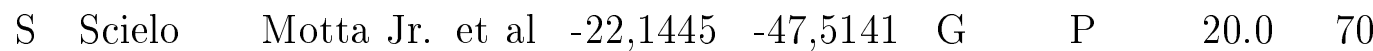
2008

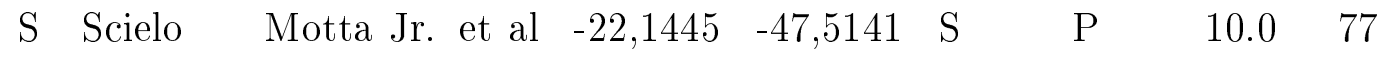
2008 


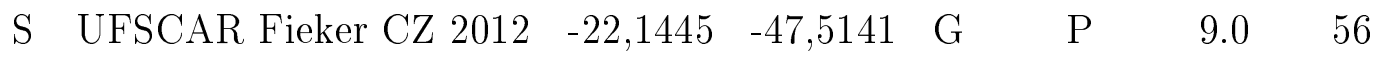

$\begin{array}{llllllll}\text { S } & \text { UFSCAR Fieker CZ } 2012 & -22,1445 & -47,5141 & \mathrm{G} & \mathrm{P} & 9.0 & 49\end{array}$

$\begin{array}{llllllll}\text { S } & \text { UFSCAR Fieker CZ } 2012 & -22,1445 & -47,5141 & \text { G } & \text { P } & 9.0 & 49\end{array}$

$\begin{array}{llllllll}\mathrm{S} & \text { UFSCAR Fieker CZ } 2012 & -22,1445 & -47,5141 & \mathrm{G} & \mathrm{P} & 9.0 & 61\end{array}$

$\begin{array}{llllllll}\mathrm{S} & \text { UFSCAR Fieker CZ } 2012 & -22,1445 & -47,5141 & \mathrm{~S} & \mathrm{P} & 9.0 & 67\end{array}$

$\begin{array}{llllllll}\text { S } & \text { UFSCAR Fieker CZ } 2012 & -22,1445 & -47,5141 & \mathrm{~S} & \mathrm{P} & 9.0 & 69\end{array}$

$\begin{array}{lllllllll}\mathrm{S} & \text { UFSCAR Fieker CZ } 2012 & -22,1445 & -47,5141 & \mathrm{~S} & \mathrm{P} & 9.0 & 78\end{array}$

$\begin{array}{llllllll}\text { S } & \text { UFSCAR Fieker CZ } 2012 & -22,1445 & -47,5141 & \mathrm{~S} & \mathrm{P} & 9.0 & 66\end{array}$

$\begin{array}{lllllllll}\mathrm{T} & \text { USP } & \text { Sendoda } 2009 & -17,5200 & -53,0700 & \mathrm{G} & \mathrm{T} & 38.0 & 36\end{array}$

$\begin{array}{llllllll}\text { U Google Tolesano- } & -18,5657 & -48,1214 & \text { F } & \text { N } & 200.0 & 26\end{array}$

Scholar Pascoli et al

2010

V Website Costa and Ro- $-19,1750 \quad-43,3450$ G $\quad$ N 241.8640 drigues 2012

$\begin{array}{llllllllll}\text { W Scielo Valadão et } & \text { al } & -15,2711 & -57,0606 & \text { F } & \text { T } & 80.0 & 141\end{array}$ 2012

$\begin{array}{lllllllll}\text { W Scielo Valadão et al } & -15,2711 & -57,0606 & \text { F } & \text { T } & 80.0 & 210\end{array}$ 2012

$\begin{array}{llllllllll}\text { W Scielo } & \text { Valadão et } & \text { al } & -15,2711 & -57,0606 & \mathrm{~S} & \mathrm{~T} & 80.0 & 194\end{array}$ 2012

$\begin{array}{lllllllll}\text { W Scielo Valadão et } & \text { al } & -15,2711 & -57,0606 & \mathrm{~S} & \mathrm{~T} & 80.0 & 165\end{array}$ 2012

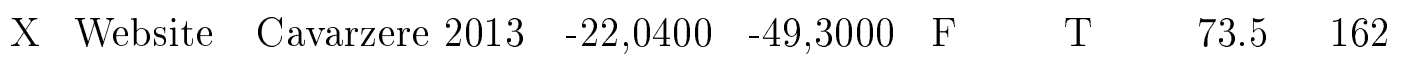

$\begin{array}{lllllllll}\text { Y Scielo Pascoal et al } & -18,5909 & -48,1803 & \mathrm{~S} & \mathrm{~T} & 320.0 & 50\end{array}$ 2013

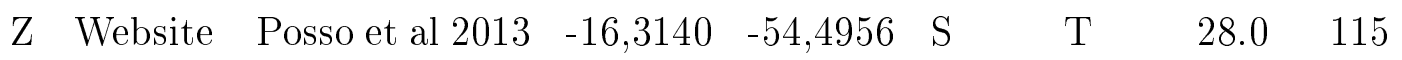

\begin{tabular}{lllllllll}
$Z$ & Website & Posso et al 2013 & $-16,3140$ & $-54,4956$ & $\mathrm{~F}$ & $\mathrm{~T}$ & 14.0 & 107 \\
\hline
\end{tabular} 
Table A.5 - Classification of phytophisiognomies used by us and the vegetation classification of study authors that lies in each of our vegetation classes. Also, in the last column, the name of each vegetation category roughly translated to English.

\begin{tabular}{lcc}
\hline Present Classification & Authors classification & English translation \\
\hline Grasslands & campo & field \\
& campo limpo & clean field \\
& campo sujo & dirty field \\
Savannas & campo rupestre & rocky field \\
& campo cerrado & field savanna \\
& parque cerrado & small savanna patches spread in field \\
Forests & cerrado sensu stricto & typical savanna \\
\hline
\end{tabular}

\section{A.3 Detailed description of statistical analyses}

Effort in mist net method can be measured in hours of sampling per net opened or even in $\mathrm{h} / \mathrm{m} 2$, which is calculated by the net area (length and high of the net) and hours of sampling. Also, the mesh size of the nets used can vary and affect the size of individuals and species caught (Piratelli, 2003). However, these informations about the net area and mesh size sometimes are not presented by the authors and the majority of studies used standard net sizes (12 m long x $2.5 \mathrm{~m}$ high, with $36 \mathrm{~mm}$ mesh size). Then, we standardized our net sampling effort unit as the number of hours per net opened, irrespectively of its area and mesh size, and we considered this unity as equivalent to one hour of observation in point/transect method. 

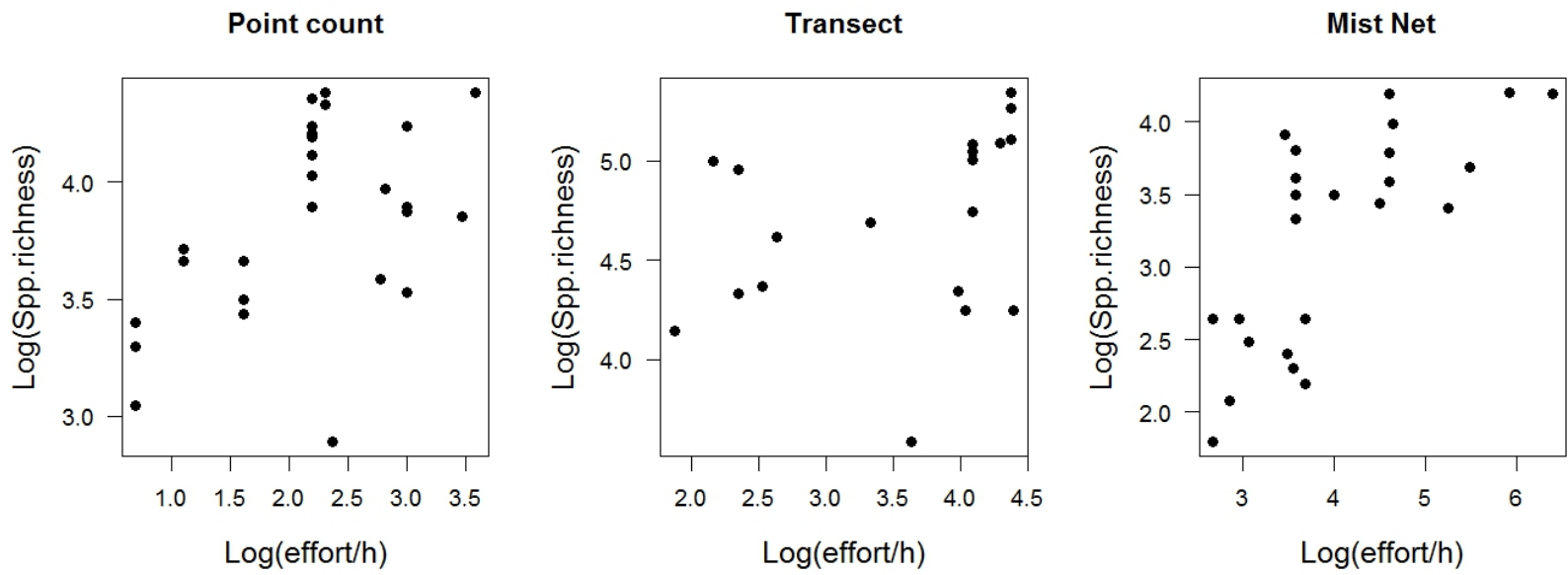

Figure A.1: Relation of Species richness and Logarithm of Sampling Effort per hour for each census method. This graphs showed linear relations among these variables, which support us in our choice of use a linear model analysis.

Table A.6 - Statistical models, their AIC values, delta AICs, degrees of freedom and models weights. Legend of Fixed effects variables: Phy = Vegetation phytophysiognomy; Met = census method, Phy:Met = interaction among Vegetation phytophysiognomy and census Method effects; Legends of Random effects: $1 \mid \operatorname{Reg}=$ random intercept effect of sampled region; $1 \mid$ Aut $=$ random intercept effect of study author; $1 \mid \mathrm{Pub}=$ random intercept effect of publication; Phy $\mid$ Aut $=$ random slope effect of author in the relation of Species richness and phytophysiognomy; $\mathrm{Phy} \mid \mathrm{Pub}=$ random slope effect of publication in the relation of species richness and phytophysiognomy; NULL $=$ no random effect used.

\begin{tabular}{lcccc}
\hline Model Fixed effects & Random effects & AIC & $\Delta$ AIC & df \\
\hline Phy + Met + Phy:Met & $1 \mid$ Reg $+1 \mid$ Aut & 670.1 & 0 & 11 \\
Phy + Met + Phy:Met & $1 \mid$ Reg $+1 \mid$ Pub & 670.6 & 0.5 & 11 \\
Phy + Met + Phy:Met & $1 \mid$ Reg $+1 \mid$ Pub $+1 \mid$ Aut & 673.0 & 2.8 & 12 \\
Phy + Met + Phy:Met & Phy $\mid$ Aut & 690.0 & 19.9 & 15 \\
Phy + Met + Phy:Met & $1 \mid$ Reg & 690.1 & 20.0 & 10 \\
Phy + Met + Phy:Met & Phy $\mid$ Pub & 691.9 & 21.7 & 15 \\
Phy + Met + Phy:Met & $1 \mid$ Pub & 705.2 & 35.1 & 10 \\
Phy + Met + Phy:Met & $1 \mid$ Aut & 707.2 & 37.0 & 10 \\
Phy + Met + Phy:Met & $1 \mid$ Pub $+1 \mid$ Aut & 707.4 & 37.3 & 11 \\
Phy + Met + Phy:Met & Met $\mid$ Aut & 709.8 & 39.7 & 15 \\
Phy + Met + Phy:Met & Met $\mid$ Pub & 710.7 & 40.5 & 15 \\
Phy + Met + Phy:Met & NULL & 2372.9 & 1702.7 & 9 \\
\hline
\end{tabular}




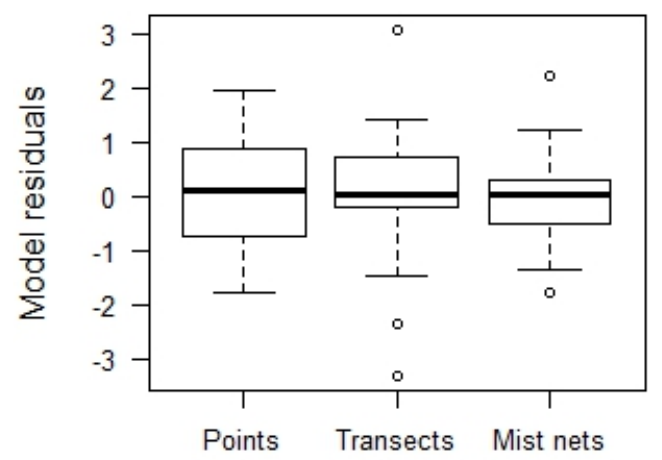

Sampling Method

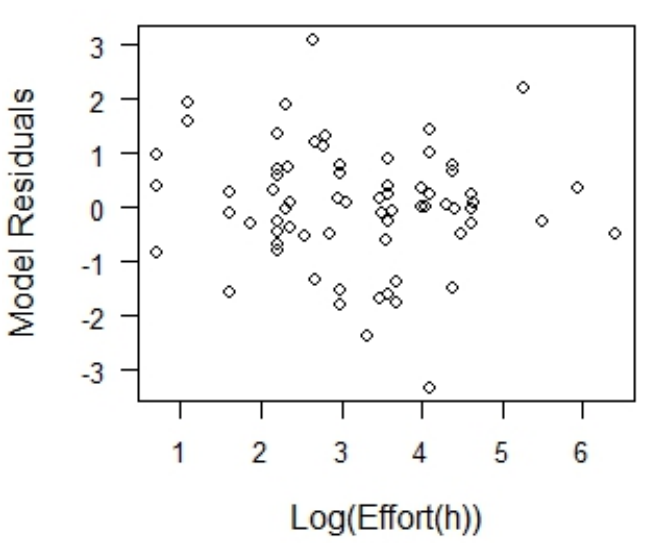

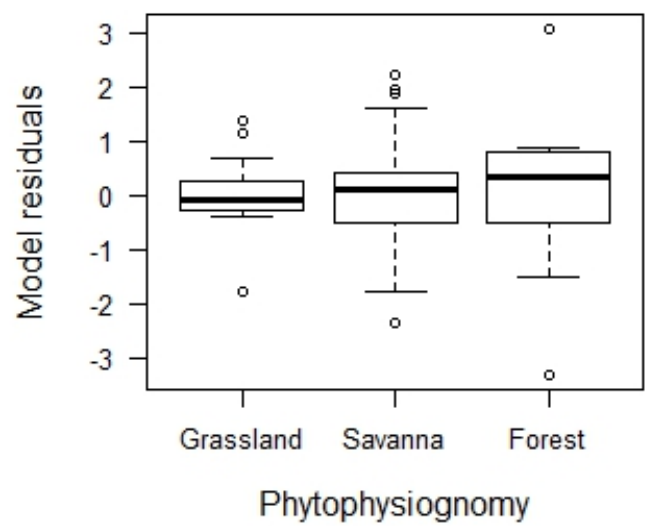

Normal QQ plot

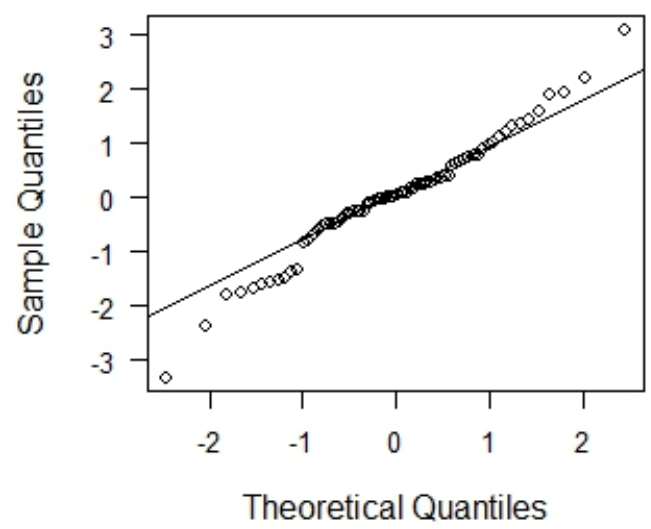

Figure A.2: Best model graphical validation for our GLMM analysis. From topleft to bottomright: Residuals distribution for census method variable, for phytophisiognomy variable and offset variable, log(sampling effort in hours. Finally, at bottomright the normal quantile-quantile plot and model residuals plotted. 


\section{Appendix B}

\section{B.1 Bayesian model codes in BUGS language}

1- Occupancy-detection model with species richness derivation in BUGS language

$\operatorname{sink}($ "occupancy-detection-predcheck.txt")

cat("

model \{

\# Priors

for( $\mathrm{k}$ in 1:nspec $)\{\#$ Loop over species

mean.psi[k] dunif $(0,1) \#$ priors of psi follwing a uniform

beta0 $[\mathrm{k}]<-\operatorname{logit}($ mean.p $[\mathrm{k}])$ \# priors of beta0 for $\mathrm{p}$ in logit scale

beta1 $[\mathrm{k}] \operatorname{dnorm}(0,0.001)$ \# priors of beta1 for $\mathrm{p}$ following a normal

mean.p $[\mathrm{k}] \quad$ dunif $(0,1)$

alpha0 $[\mathrm{k}]<-\operatorname{logit}($ mean.p $[\mathrm{k}])$ \# priors of alpha0 for $\mathrm{p}$ in logit scale

alpha1 $[\mathrm{k}] \operatorname{dnorm}(0,0.001) \#$ priors of alpha1 for $\mathrm{p}$ following a normal

alpha2 $[\mathrm{k}] \operatorname{dnorm}(0,0.001) \#$ priors of alpha2 for $\mathrm{p}$ following a normal

alpha3 $[\mathrm{k}] \operatorname{dnorm}(0,0.001) \#$ priors of alpha3 for $\mathrm{p}$ following a normal

\}

\# Ecological model for latent occurrence z (process model)

for( $\mathrm{k}$ in 1:nspec) $\{\#$ Loop over species

for (i in 1:M) \{ \# Loop over sites

$\operatorname{logit}(\operatorname{psi}[\mathrm{i}, \mathrm{k}])<-\operatorname{beta} 0[\mathrm{k}]+\operatorname{beta} 1\left[\mathrm{k}{ }^{*} \operatorname{veg}[\mathrm{i}]\right.$

$\mathrm{z}[\mathrm{i}, \mathrm{k}] \quad \mathrm{dbern}(\operatorname{psi}[\mathrm{i}, \mathrm{k}])$ 
\}

\}

\# Observation model for observed data $\mathrm{Y}$

for(k in 1:nspec) \{ \# Loop over species

for (i in 1:M) \{ \# Loop over sites

for $(\mathrm{j}$ in $1: \mathrm{J}[\mathrm{i}])$ \{ \# Loop over occasions

$\operatorname{logit}(\mathrm{p}[\mathrm{i}, \mathrm{j}, \mathrm{k}])<-$ alpha0 $[\mathrm{k}]+$ alpha1 $[\mathrm{k}]^{*} \operatorname{veg}[\mathrm{i}]+$ alpha2 $[\mathrm{k}]^{*}$ dates $[\mathrm{i}]+$ alpha3 $[\mathrm{k}]^{*}$ mtemp $[\mathrm{i}]$

$\operatorname{mup}[\mathrm{i}, \mathrm{j}, \mathrm{k}]<-\mathrm{z}[\mathrm{i}, \mathrm{k}] * \mathrm{p}[\mathrm{i}, \mathrm{j}, \mathrm{k}]$

Ysum $[\mathrm{i}, \mathrm{j}, \mathrm{k}] \quad \mathrm{dbern}(\operatorname{mup}[\mathrm{i}, \mathrm{j}, \mathrm{k}])$

\}

\}

\}

\# Derived quantities

for (i in 1:M) \{ \# Loop over sites

Nsite[i] $<-\operatorname{sum}(z[i]) \$,$# Add up number of occurring species at each site$

\}

\} \# end model

",fill=TRUE)

$\operatorname{sink}()$ 


\section{2- Metanalysis model with discrepancy values calculation in BUGS language}

$\operatorname{sink}(" m e t a a n a l y s i s-p r e d c h e c k . t x t ")$

cat ("

model \{

\# Priors

for(v in 1:2)\{ \# Priors for intercept and polynomial coefficients

$\operatorname{beta}[\mathrm{v}] \operatorname{dnorm}(0,0.0001)$

\}

tau.site $<-$ pow $($ sd.site,,-2$)$

sd.site dunif $(0,10)$

\# Likelihood

for $(\mathrm{i}$ in $1: n)\{$

$\mathrm{N}[\mathrm{i}] \operatorname{dnorm}(\mathrm{muN}[\mathrm{i}]$, tau.psd[i]) \# Measurement error model for estimated $\mathrm{N}$ tau.psd[i] <- pow(psd[i], -2) \# 'Known' part of residual: meas. error muN[i] <- beta[1] + beta[2] * ele[i] + eps.site[i] \# add another source of uncertainty eps.site[i] $\operatorname{dnorm}(0$, tau.site) \# this is the usual 'residual'

\# This section was adapted to Marc and Royle book code

\# Fit assessments: Chi-squared test statistic and posterior predictive check $\operatorname{chi} 2[\mathrm{i}]<-\operatorname{pow}((\mathrm{N}[\mathrm{i}]-\mathrm{muN}[\mathrm{i}]), 2) /(\operatorname{muN}[\mathrm{i}]+\mathrm{e}) \#$ obs.

Nmax.new[i] dnorm(muN[i], tau.psd[i]) \# Replicate (new) data set

chi2.new $[\mathrm{i}]<-\operatorname{pow}((\mathrm{Nmax} \cdot n e w[\mathrm{i}]-\mathrm{muN}[\mathrm{i}]), 2) /(\operatorname{muN}[\mathrm{i}]+\mathrm{e}) \# \exp$.

\}

\# Add up discrepancy measures for entire data set

fit $<-\operatorname{sum}(\operatorname{chi} 2[]) \#$ Omnibus test statistic actual data

fit.new $<-$ sum(chi2.new[]) \# Omnibus test statistic replicate data

\# range of data as a second discrepancy measure

obs.range $<-\max (\mathrm{N}[])-\min (\mathrm{N}[])$

exp.range $<-\max (N \max . n e w[])-\min ($ Nmax.new []$)$

\# Get predictions for plot 
for(i in 1:npred) \{

Npred[i] <- beta[1] + beta[2]* pred.ele[i]

\}

\} \# end model

",fill=TRUE)

$\operatorname{sink}()$

\section{B.2 Posterior predictive checks of metanalysis models fit}
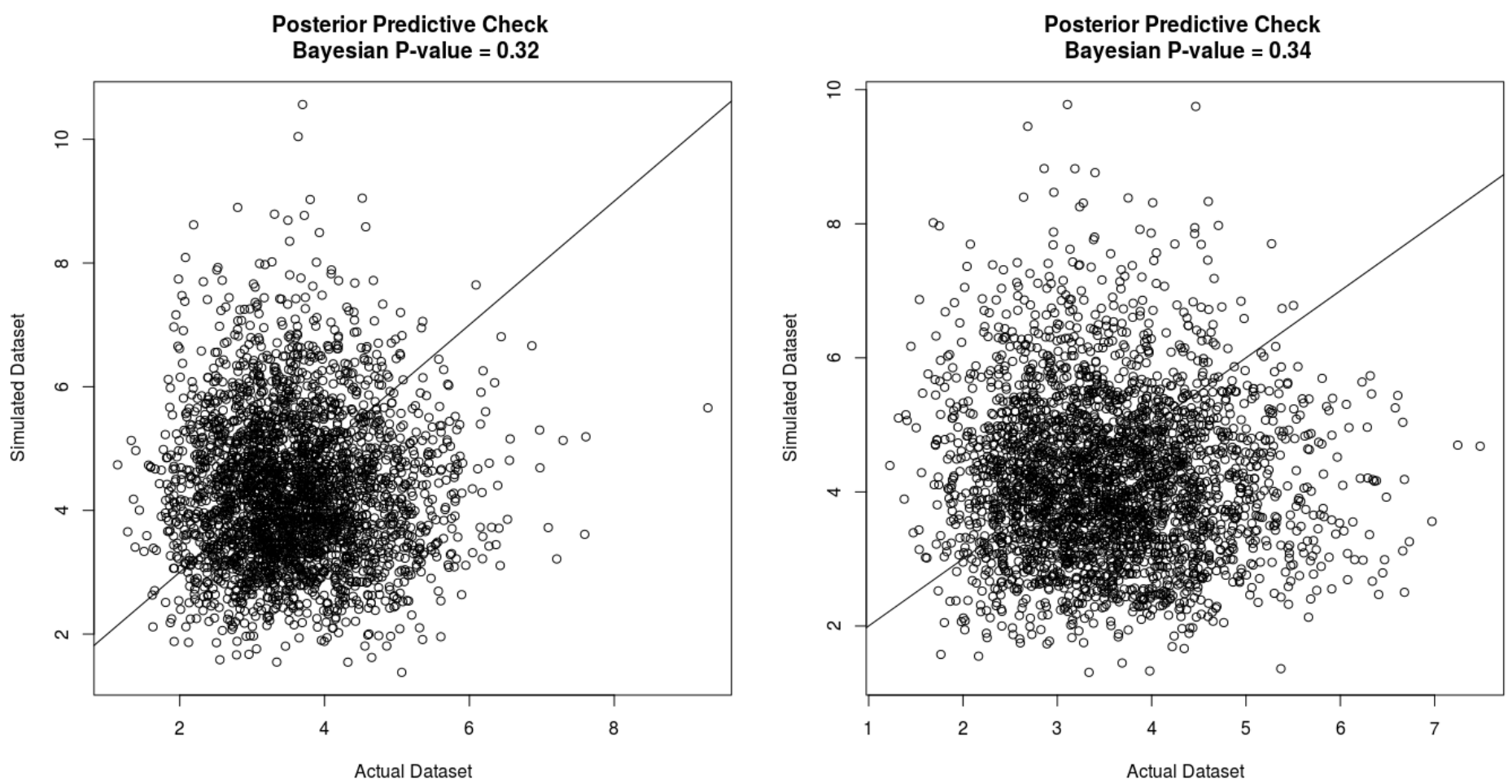

Figure B.1: Posterior predictive checks for the Metanalysis model fit assessment. The points are the values of chi-square discrepancy measures calculated between the observed and expected data and also between replicated and expected data. The lines are 1:1 identity lines, that represents equal values for both discrepancy measures. Bayesian $\mathrm{p}$ values were calculated by using "ppcheck" function of jagsUI $\mathrm{R}$ package. If $\mathrm{p}$ values are lower than 0.025 or greater than 0.975 , it means that the model fit is inadequate. 


\section{B.3 Table of species sampled during surveys}

Table B.1 - Species, Orders and Families sampled during surveys. Species were ordered by decreasing number of detections (N. det.) to highlight the 38 most detected species (N.det. $\geq 20$ ).

\begin{tabular}{|c|c|c|c|}
\hline Species & Order & Family & N. Det. \\
\hline Zonotrichia capensis & Passeriformes & Passerellidae & 191 \\
\hline Elaenia chiriquensis & Passeriformes & Tyrannidae & 150 \\
\hline Eupsittula aurea & Psittaciformes & Psittacidae & 148 \\
\hline Sporophila plumbea & Passeriformes & Thraupidae & 145 \\
\hline Ammodramus humeralis & Passeriformes & Passerellidae & 127 \\
\hline Mimus saturninus & Passeriformes & Mimidae & 125 \\
\hline Eupetomena macroura & Apodiformes & Trochilidae & 114 \\
\hline Saltatricula atricollis & Passeriformes & Thraupidae & 111 \\
\hline Troglodytes musculus & Passeriformes & Troglodytidae & 96 \\
\hline Synallaxis albescens & Passeriformes & Furnariidae & 89 \\
\hline Elaenia cristata & Passeriformes & Tyrannidae & 81 \\
\hline Formicivora rufa & Passeriformes & Thamnophilidae & 77 \\
\hline Emberizoides herbicola & Passeriformes & Thraupidae & 76 \\
\hline Camptostoma obsoletum & Passeriformes & Tyrannidae & 75 \\
\hline Heliactin bilophus & Apodiformes & Trochilidae & 75 \\
\hline Lepidocolaptes angustirostris & Passeriformes & Dendrocolaptidae & 68 \\
\hline Gnorimopsar chopi & Passeriformes & Icteridae & 56 \\
\hline Elaenia flavogaster & Passeriformes & Tyrannidae & 55 \\
\hline Suiriri affinis & Passeriformes & Tyrannidae & 52 \\
\hline Cyanocorax cristatellus & Passeriformes & Corvidae & 40 \\
\hline Tachornis squamata & Apodiformes & Apodidae & 38 \\
\hline Thamnophilus torquatus & Passeriformes & Thamnophilidae & 38 \\
\hline Neothraupis fasciata & Passeriformes & Thraupidae & 37 \\
\hline Melanopareia torquata & Passeriformes & Melanopareiidae & 36 \\
\hline
\end{tabular}




\begin{tabular}{|c|c|c|}
\hline Cyclarhis gujanensis & Passeriformes & Vireonidae \\
\hline Rhynchotus rufescens & Tinamiformes & Tinamidae \\
\hline Cypsnagra hirundinacea & Passeriformes & Thraupidae \\
\hline Schistochlamys ruficapillus & Passeriformes & Thraupidae \\
\hline Euscarthmus rufomarginatus & Passeriformes & Tyrannidae \\
\hline Nystalus chacuru & Galbuliformes & Bucconidae \\
\hline Cariama cristata & Cariamiformes & Cariamidae \\
\hline Xolmis cinereus & Passeriformes & Tyrannidae \\
\hline Amazona aestiva & Psittaciformes & Psittacidae \\
\hline Chlorostilbon lucidus & Apodiformes & Trochilidae \\
\hline Phacellodomus rufifrons & Passeriformes & Furnariidae \\
\hline Tangara palmarum & Passeriformes & Thraupidae \\
\hline Euphonia chlorotica & Passeriformes & Fringillidae \\
\hline Myiophobus fasciatus & Passeriformes & Tyrannidae \\
\hline Myiarchus swainsoni & Passeriformes & Tyrannidae \\
\hline Alipiopsitta xanthops & Psittaciformes & Psittacidae \\
\hline Milvago chimachima & Falconiformes & Falconidae \\
\hline Myiarchus tyrannulus & Passeriformes & Tyrannidae \\
\hline Crypturellus parvirostris & Tinamiformes & Tinamidae \\
\hline Knipolegus lophotes & Passeriformes & Tyrannidae \\
\hline Tyrannus albogularis & Passeriformes & Tyrannidae \\
\hline Amazilia fimbriata & Apodiformes & Trochilidae \\
\hline Piranga flava & Passeriformes & Cardinalidae \\
\hline Polioptila dumicola & Passeriformes & Polioptilidae \\
\hline Columbina squammata & Columbiformes & Columbidae \\
\hline Cantorchilus leucotis & Passeriformes & Troglodytidae \\
\hline Turdus leucomelas & Passeriformes & Turdidae \\
\hline Colaptes campestris & Piciformes & Picidae \\
\hline Diopsittaca nobilis & Psittaciformes & Psittacidae \\
\hline
\end{tabular}




\begin{tabular}{|c|c|c|}
\hline Hemitriccus margaritaceiventer & Passeriformes & Rhynchocyclidae \\
\hline Sublegatus modestus & Passeriformes & Tyrannidae \\
\hline Myiarchus ferox & Passeriformes & Tyrannidae \\
\hline Xolmis velatus & Passeriformes & Tyrannidae \\
\hline Ara ararauna & Psittaciformes & Psittacidae \\
\hline Caracara plancus & Falconiformes & Falconidae \\
\hline Formicivora melanogaster & Passeriformes & Thamnophilidae \\
\hline Pachyramphus polychopterus & Passeriformes & Tityridae \\
\hline Phaethornis pretrei & Apodiformes & Trochilidae \\
\hline Ramphastos toco & Piciformes & Ramphastidae \\
\hline Stelgidopteryx ruficollis & Passeriformes & Hirundinidae \\
\hline Thectocercus acuticaudatus & Psittaciformes & Psittacidae \\
\hline Furnarius rufus & Passeriformes & Furnariidae \\
\hline Patagioenas picazuro & Columbiformes & Columbidae \\
\hline Brotogeris chiriri & Psittaciformes & Psittacidae \\
\hline Rupornis magnirostris & Accipitriformes & Accipitridae \\
\hline Saltator similis & Passeriformes & Thraupidae \\
\hline Schistochlamys melanopis & Passeriformes & Thraupidae \\
\hline Schoeniophylax phryganophilus & Passeriformes & Furnariidae \\
\hline Athene cunicularia & Strigiformes & Strigidae \\
\hline Galbula ruficauda & Galbuliformes & Galbulidae \\
\hline Hemithraupis guira & Passeriformes & Thraupidae \\
\hline Heterospizias meridionalis & Accipitriformes & Accipitridae \\
\hline Melanerpes candidus & Piciformes & Picidae \\
\hline Phacellodomus ruber & Passeriformes & Furnariidae \\
\hline Pitangus sulphuratus & Passeriformes & Tyrannidae \\
\hline Setophaga pitiayumi & Passeriformes & Parulidae \\
\hline Sporophila nigricollis & Passeriformes & Thraupidae \\
\hline Culicivora caudacuta & Passeriformes & Tyrannidae \\
\hline
\end{tabular}




\begin{tabular}{|c|c|c|}
\hline Tangara cayana & Passeriformes & Thraupidae \\
\hline Campephilus melanoleucos & Piciformes & Picidae \\
\hline Chaetura meridionalis & Apodiformes & Apodidae \\
\hline Columbina picui & Columbiformes & Columbidae \\
\hline Dryocopus lineatus & Piciformes & Picidae \\
\hline Hemitriccus striaticollis & Passeriformes & Rhynchocyclidae \\
\hline Megarynchus pitangua & Passeriformes & Tyrannidae \\
\hline Porphyrospiza caerulescens & Passeriformes & Thraupidae \\
\hline Progne tapera & Passeriformes & Hirundinidae \\
\hline Sicalis flaveola & Passeriformes & Thraupidae \\
\hline Synallaxis frontalis & Passeriformes & Furnariidae \\
\hline Volatinia jacarina & Passeriformes & Thraupidae \\
\hline Baryphthengus ruficapillus & Coraciiformes & Momotidae \\
\hline Basileuterus culicivorus & Passeriformes & Parulidae \\
\hline Cathartes aura & Cathartiformes & Cathartidae \\
\hline Colibri serrirostris & Apodiformes & Trochilidae \\
\hline Falco femoralis & Falconiformes & Falconidae \\
\hline Geranoaetus albicaudatus & Accipitriformes & Accipitridae \\
\hline Herpsilochmus longirostris & Passeriformes & Thamnophilidae \\
\hline Machetornis rixosa & Passeriformes & Tyrannidae \\
\hline Nystalus maculatus & Galbuliformes & Bucconidae \\
\hline Patagioenas cayennensis & Columbiformes & Columbidae \\
\hline Picumnus albosquamatus & Piciformes & Picidae \\
\hline Psarocolius decumanus & Passeriformes & Icteridae \\
\hline Sicalis citrina & Passeriformes & Thraupidae \\
\hline Tachyphonus rufus & Passeriformes & Thraupidae \\
\hline Tangara sayaca & Passeriformes & Thraupidae \\
\hline Taraba major & Passeriformes & Thamnophilidae \\
\hline Thamnophilus pelzelni & Passeriformes & Thamnophilidae \\
\hline
\end{tabular}


Tyrannus melancholicus

Aphantochroa cirrochloris

Buteo brachyurus

Charitospiza eucosma

Cnemotriccus fuscatus

Colaptes melanochloros

Columbina talpacoti

Coragyps atratus

Dacnis cayana

Falco sparverius

Glaucidium brasilianum

Heliomaster squamosus

Herpetotheres cachinnans

Hirundinea ferruginea

Legatus leucophaius

Myiothlypis leucophrys

Myrmorchilus strigilatus

Nemosia pileata

Orthopsittaca manilatus

Piaya cayana

Progne chalybea

Psittacara leucophthalmus

Ramphocelus carbo

Sturnella superciliaris

Tyrannus savana

Urubitinga coronata

Veniliornis mixtus

Veniliornis passerinus
Passeriformes

Apodiformes

Accipitriformes

Passeriformes

Passeriformes

Piciformes

Columbiformes

Cathartiformes

Passeriformes

Falconiformes

Strigiformes

Apodiformes

Falconiformes

Passeriformes

Passeriformes

Passeriformes

Passeriformes

Passeriformes

Psittaciformes

Cuculiformes

Passeriformes

Psittaciformes

Passeriformes

Passeriformes

Passeriformes

Accipitriformes

Piciformes

Piciformes
Tyrannidae

Trochilidae

1

Accipitridae

1

Thraupidae

1

Tyrannidae

1

Picidae

Columbidae

1

Cathartidae

1

Thraupidae

1

Falconidae

1

Strigidae

1

Trochilidae

1

Falconidae

1

Tyrannidae

1

Tyrannidae

1

Parulidae

1

Thamnophilidae

1

Thraupidae

1

Psittacidae

1

Cuculidae

1

Hirundinidae

1

Psittacidae

1

Thraupidae

1

Icteridae

1

Tyrannidae

1

Accipitridae

1

Picidae

1

Picidae 
B.4 Results of species richness and occupancy using all species data

Psi $\sim$ PC1,p PC1+Dates+Temp

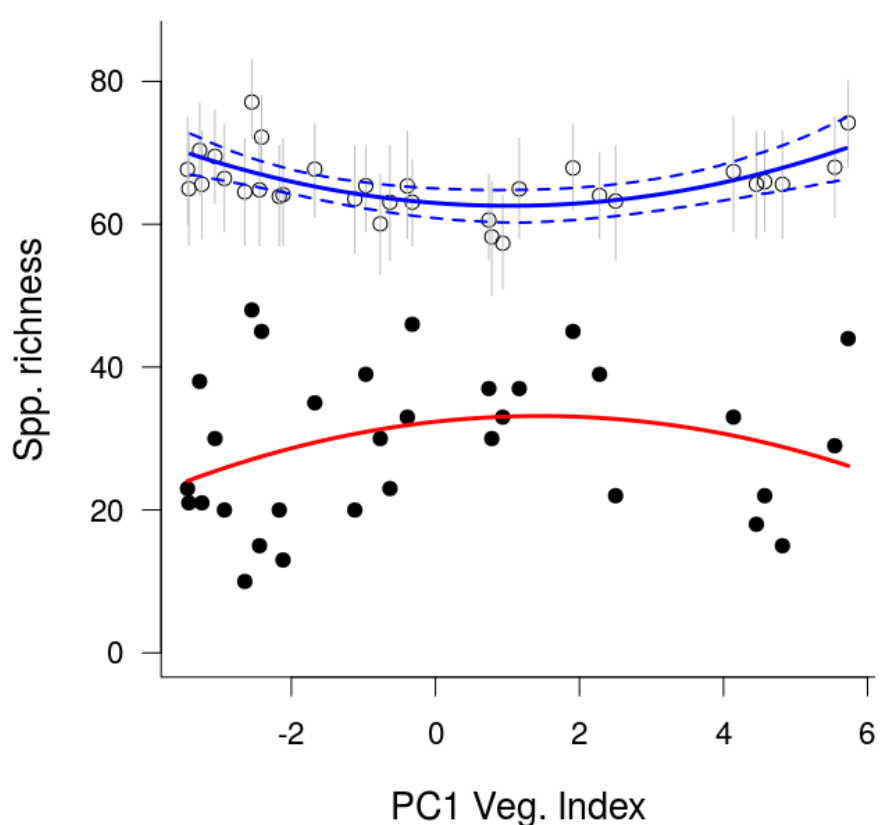

Psi PC2,p PC2+Dates+Temp

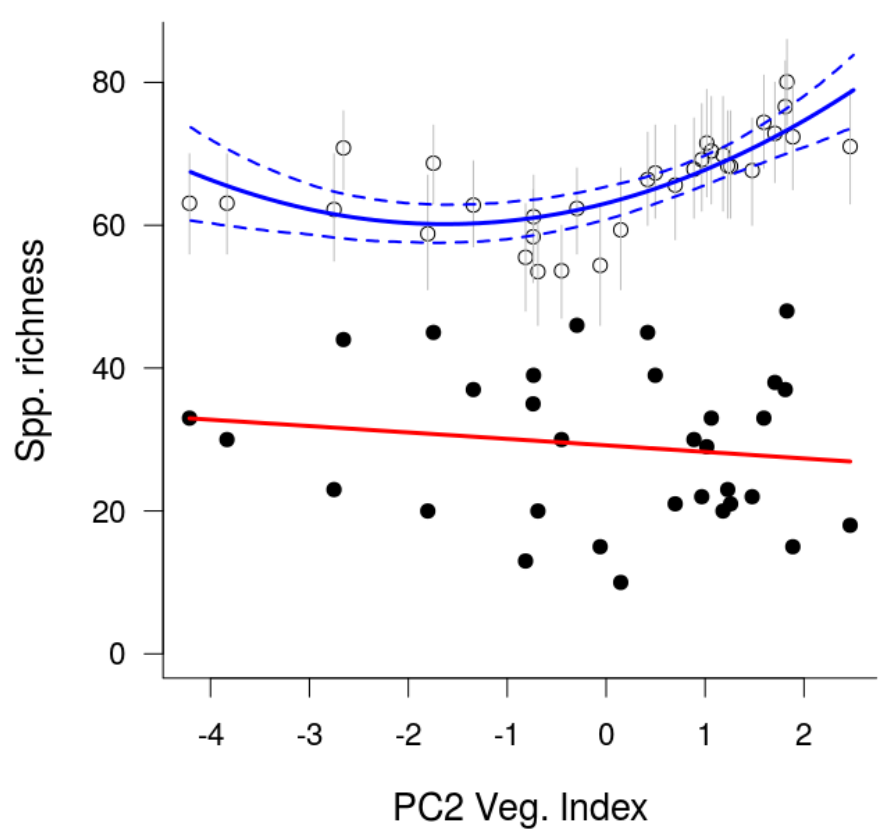

Figure B.2: Relationship of estimated and observed (naive) species richness with vegetation structure covariates. White points and gray lines are the estimated species richness and $95 \%$ credibility intervals around the estimates. Solid blue lines are the species richness-vegetation structure model predictions and dashed blue lines are the $95 \%$ lower and upper credibility intervals. Solid black circles are the observed (naive) species richness for each site and solid red line is the prediction of a quadratic glm Normal-error model fitted to naive data. 

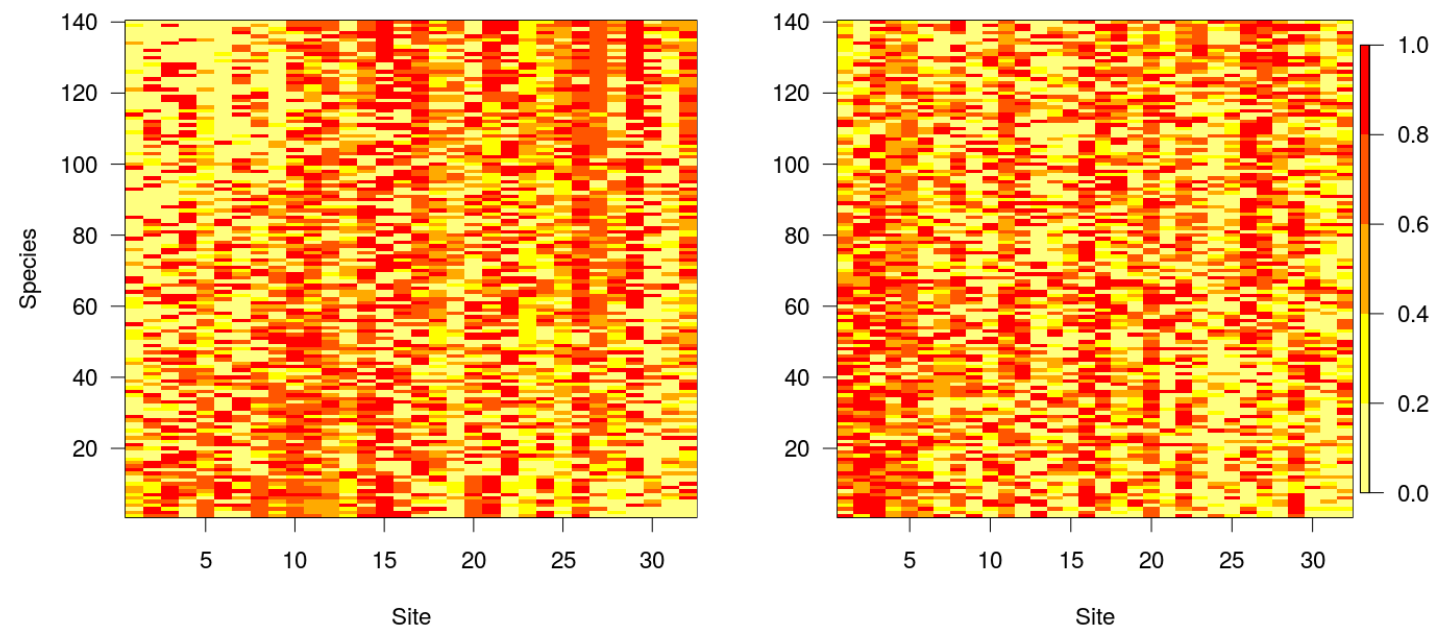

Figure B.3: Occupancy patterns of species for the two vegetation gradient covariates. Cells colors are "warmer" where species presented higher occupancy values at each site. Species were ordered in rows by the mean of PC1 (or PC2) score divided by species occupancy at that site. In turn, the columns were ordered by increasing values of each habitat covariate. 